THE, SOILS OF MISSOURT

by

Henry H. Krusekopf, B. S. A.

SUBMITTFD IN PARTIAL FULFILMENT OF THE

REQUIREMENTS FOR THE DEGREE OF

MASTER OF ARTS

in the

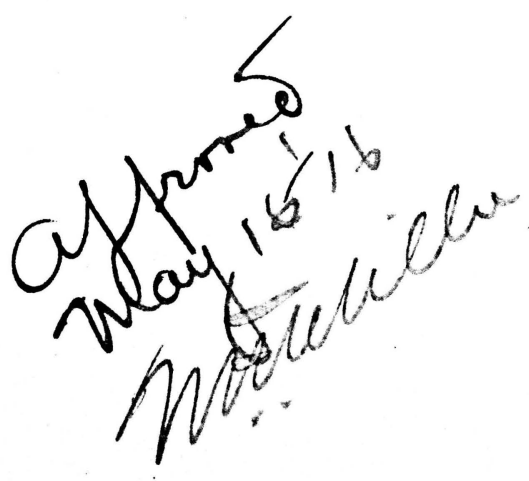

GRADUATE SCHOOL

of the

UNIVERSITY OF MISSOURI

1916 
Contents

Introduction

Object of Reconnaissance Survey

Previous Work

Physiography

Geology

Topography

Altitude

So118

So1l Classification

Glacial and Loessal So1ls

Knox silt loam 28

Marshall silt loam 33

Grundy silt loam 38

Putnam silt loam 41

Shelby loam 46

Lindley loam: 49

Wabash silt loam 53

Residual Prairie So1ls of West Missourl 58

Summit silt loam $\quad \therefore \quad 61$

Oswego silt loam $\because \because \because$

Cherokee silt loam 67

Bates fine sandy loam 70

Osage silt loam

Solds of the Ozark Region 77

Hagerstown silt loam 81

Union gilt loam 85

Crawford graveliy loam 90

Lebanon silt loam 95

Tilsit silt loam 99

Boone loam 103

Clarkaville gravelly loam 105

Clarksville stony loam 108

Ashe stony loam 110

Hunt1ngton loam 111

Southeast Lowland So11s 114

Sarpy fine sandy loam 118

Lintonia silt loam 123

Lintonia fine sandy loam 125

Sharkey clay loam 128

Waverly silt loam 133

Waverly fine sandy loam 137 


\section{THE SOILS OF MISSOURI}

The increasing demand for the production of larger crops have made apparent the need of a greater knowledge concerning o0118. Without such knowledge the investigational work on so1ls conducted by Agricultural Experiment Stations and indivicuals will lose much of its significance. No definite conclusions can be drawn from the results of the experiments unless the character and the distribution of the soil has been determined. More than 130 soil types have already been discovered in the progress of the soll survey work in Misscurl. The existence of such a great number of types makes evident the need of a study of their differences and relations, in. order that their influence upon the growth of plants may be understood.

In the variableness of soll conditions, few states are comparable to Missouri. In fact, it may be considered the meeting ground of all the important soli reglons of the Miss18sippl Valley. Thus, the extensive areas of glacial and loessal soll of the northern part of the state are closely related to the glacial regions of the states to the north and east. The pralries of restern Missourl form the eastern edge of the Great Plains region extending west to the Rocky Mountains. The Iimestone solls of the Ozark region are comparable to the so1lo of oimflar origin in Arkansas, Kentucky, and Tennessee. The southeast Lowlands represent the northern 
extension of the costal plains region of the southern otates. The resultant of euch varied soll conditions is a varied agriculture. It can be sald of the latter that it is neither northern nor southern, eastern nor western, but possesses the characteristics of all of these. To make possible, therefore, a greater agricultural development of the state, accurate and detalled knowledge of the so11,--1ts character, varieties, capabilities and adaptations--1s of great importance.

\section{Object of Reconnaissance Survey}

It 18 the purpose of this thesis to describe briefly the origin, distribution, and character of the so1ls in the different parts of the State, as determined by extensive field and laboratory studies and experiments, and to show their composi-. tion, utilization, management and adaptations. A special effort has been made to indlcate the causes of the characterlatics of each soll type PER SE, and the causes for the variations of the solls of the state as a whole.

\section{Previous Work}

Practically all the early work on the solls of Missouri was by geologists, and the early writings appear in various geological reports and publications. One of the earliest and most prolif1o contributors was G. C. Swallow, who in 1855 described in a general way the solis of Missourl, and also classifled them by their indigenous trees and other plants (1) A general description of Missourl so11s by G. C. Broadhead appeared In $1874(2)$. Numerous other geologlcal workers made mention of 
the general soll characters of each area covered by a geological survey(3). It is interesting to note in this connection that in these early writings little effort was made to show the origin of the soils, much less to base their classification on geologloal origin.

The beginning of a systematic classification and mapping of the solls of Missourl dates back to 1902 when the U. S. Bureau of Solls made a detalled soll survey of Howell county. In 1905 the Missour1 so1I survey was organized and in 1909 a plan of cooperation between the Missourl soli survey and the U. S. Bureau of Solls was agreed upon. Since that time all so11 survey work in the State has been done by these two organlzations working cooperatively.

The flrot general soll map of the State was made by Prof. Marbut in 1904 for the Louisiana Purchase Exposition(4). The divisions were very general, and only the broad physiograph1c areas were recognized. While geclogy forms the princlpal basis of the classification, other factors such as texture, color, percentage of stone, and topography were also. taken into consideration.

A regional soll map of the Ozarks(5) was published in 1910, and a revision and amplification of the same in $1914^{(6)}$. Here again geology forms the principal basis of classification. From this brlef resume of the more important work which has been done in classifying the so1ls of kissourl, it can be seen that this line of soll study has been carried on for a considerable time, and has been undergoing a constant development. 
Physiography

To furnish a clearer understanding of the soils of Missouri, a brief discussion of the factors determining their variableness and distribution will be given. The most important of these are geology and topography; the former determines the origin and character, while the latter determines to a large extent the economic utilization of the soll. (The relation of 80118 to climate and to vegetation is appreclated, but such changes as have been produced by these factors will be discussed in connection with the description of each so11 type.)

\section{Ceology}

The geological history of Missouri is complex both in age and composition. In southeastern Hissouri the oldest and the most recent formations are seen almost side by side. In kind, the rocks range from massive (granite) to the varlous forms of bedded rock (limestone, sandstone, and shale). In general, it 18 only in the southern part of the state-south of the Missourl River--that the indurated rocks lie. near the surface, being for the most part covered only by the debris of their own decomposition. In the northern part of the State, with few exceptions, the rocks are everywhere covered w1th a thick mantle of unconsolidated material deposIted by glacial and aeolian action during Pleistocene times. 
The cryatalline rocks, confined ontirely to the St. Franco1s Nountalns in the southeastern part of the State, are the oldest and lowest geologically (Plate I). Above them, and occurring in more or 188 concentric rings around this basal structure, are several bods of limestone and sandstone which make up the greater part of the Ozark region. They belong to the Pre-Cambrian, Cambrian, Ordorlclan, S1lurian, Deron1an, Mississipplan, and Pennoyiranian systems. In the following table(7) are given in tabular form, beginning with the highest, a for of the most important horizons of these var10us formations. 


\section{Quaternary \\ Tertsary \\ Pennsy Iranian}

M1881881pp1an

Devonian

S1Lurian

Ordovi cian

Upper Cambrian (Ozarkian

of E. 0. UIrIch)

Midle Cambrian (Taconic or Cambrian, restrioted, of E. O. Uirich)

Pre-Cambrian
AlIuvium

Iowan Loes8

Lafayette gravel

Misecurian

Des Molnes

Chester

St. Louls

Spergen

Warsan

Keokuk

Burlington

Chouteau

Hann1bal

Loule Lana

Grand Tower

Clear Creek

Basley

Bainbridge

KimmsF10k

Plattin (Trenton)

Joach1m

St. Peter:

Jefferson City

Roub1doux (Incl. Bolln sandstone)

Gasconade (Inol. Gunter sandstone)

Proctor

Bminence

Potos1

\section{Eirins}

Bonneterre

Lamot te

Dlabare

Grand to

Rhyolito 


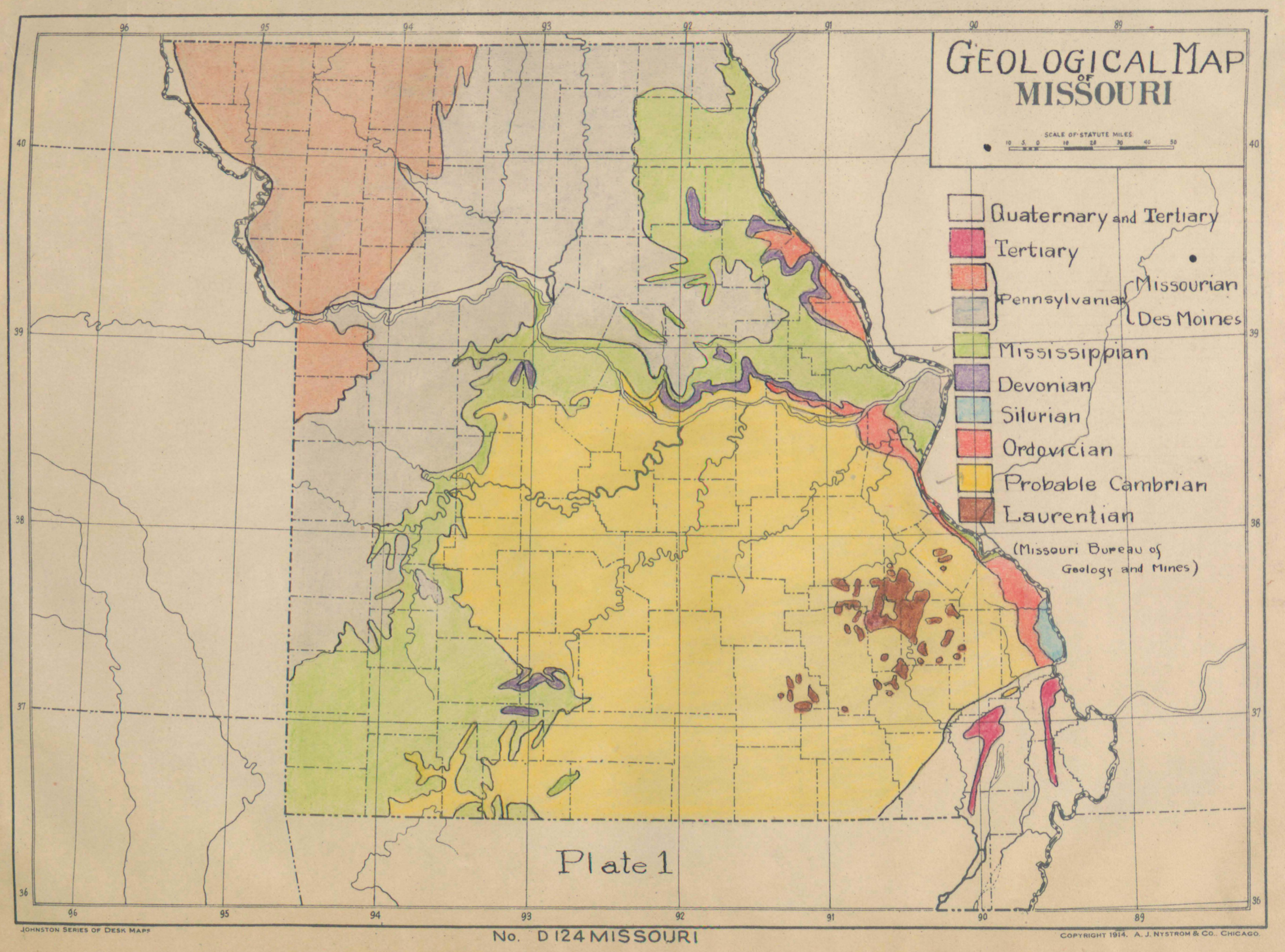


The processes of deformation and erosion have been such as to cause these several beds to occur in this form. In the Tertiary period the rocks of the Ozark region were oubjected to a gentle folding with the greatest uplift in the St. Francols Mountain region. Th1s folding produced a dome-like otructure with the rocks gently dipping in all directions from the center. (Plate II)(8a). In consequence of this uplift, erosion was accelerated with the result that the overlying rocks were stripped from the Ozark dome. The erosion was long and vigorous so that hundreds of feet of rock were removed and in the area of greatest uplift the old floor of 1gneous rocks was exposed. The process, indeed, 18 still in progress. The higher and younger rocks thus orlginally extended across the Ozarks, but have receded scores of miles from the center of uplift. The uplifted edges of the various formations are belng worn back from the center, not evenly, but irregularly, retreating more rapidiy where erosion is most vigrorous.

Each formation possesses characters more or less distinct from those adjacent to it on elther side. The character of the 8011 will thus reflect in a more or less modified form the character of 1ts parent material. Marked peculiarities of solls can generally be traced to similar geological causes.

The several sandstone formations are comparatively thin, and the grante is exposed in small areas only, so that these two rocks are of little importance as sources of soll material. That part of southern Missouri included in the Ozark region, therefore, is essentially a region of limestone rocks. Some 


\section{Plate II}
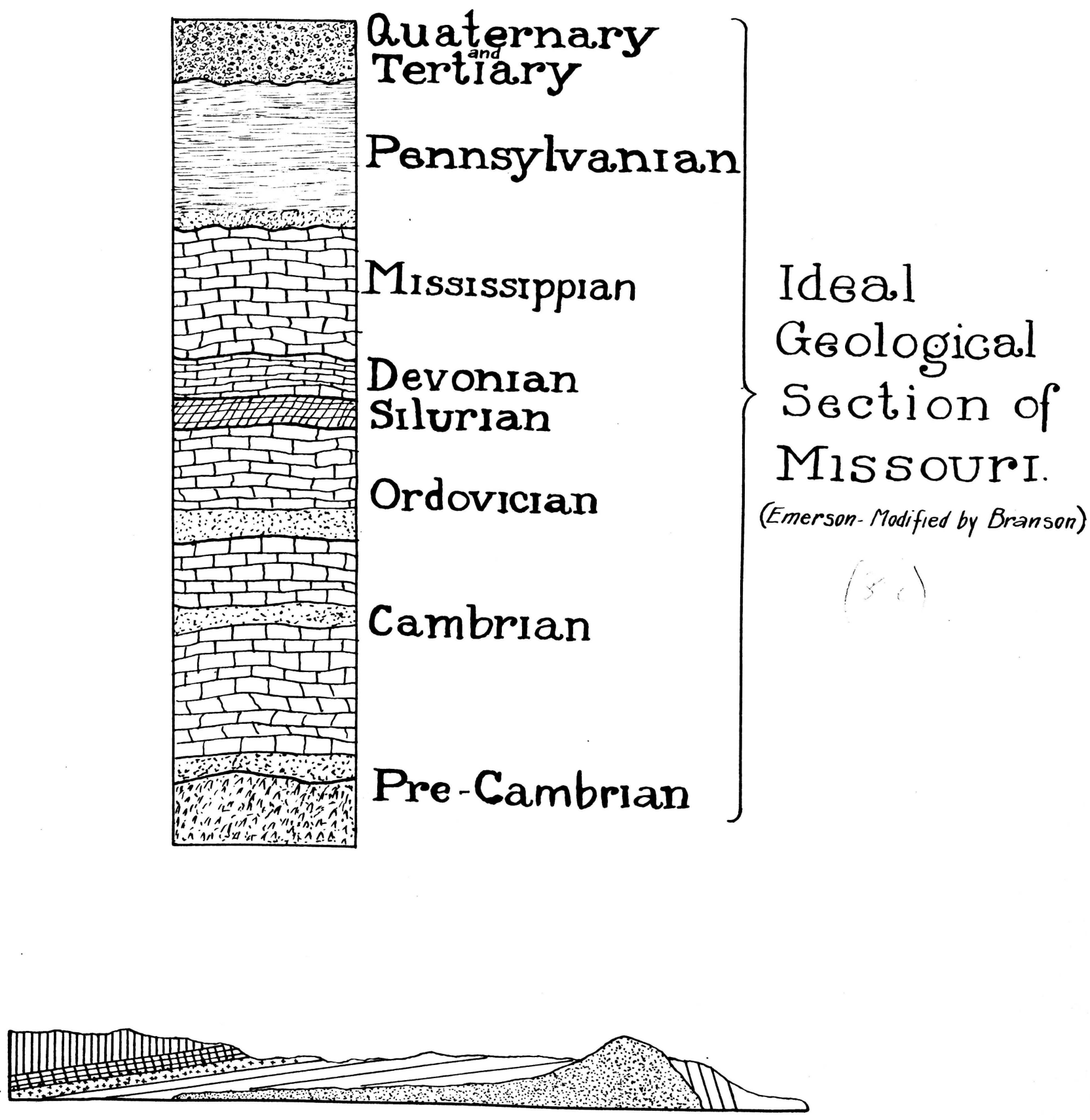

$\square$ Quaternary and Tertiary Devonian m监血 Pennsylvanian

E Cambrian-Ordoviciàn-Silurian Mississippian. Pre-Cambrian Geological Section (Northwest - Southeast) of Missouri 
beds are pure carbonates or practically so, but the majority. contain a high percentage of siliceous matter. Some beds, In fact, have been wholly replaced by silica in the form of chert.

The Mississippian Iimestone of the Lower Carboniferous forms a continuous belt around the Ozark region just described. It has a wide distribution, and covers extensive areas in southwestern and northeastern Missour1. It is made up chiefly of beds of massive, crystalilne pure limestone, with a rather large amount of chert. Of the several beds in the Mississippian group, the Burlington 1s by far the most important. It is a very pure, coarse grained, highly fossiliferous lime carbonate, containing a moderate amount of chert. The decomposition of this rock gives rise to moderately gravelly, but rather productive so118.

All that part of Missouri lying north and west of an irregular line extending from the southeast corner of Clark County to the northwest corner of Jasper County is underlaid by Carboniferous rocks. The lower beds of these consist chiefly of shales and sandstones, and the so11s they form are elther clayey or sandy. In the region of the upper coal measures there is a greater alternation of shales with Iimestones. In general, the various horizons of the Carboniferous rocks occur in 1rregular belts, extending from northeast to southwest. This condition is of great importance in determining the distribution of the various solls. 
The northern part of the State, north of the Missouri River, with the exception of a few small areas, was covered during Plelstocene time by the ice sheet of the Kansan glaciation. Upon receding the latter left a mantle of drift from 10 to 200 feet in thickness, consisting of the ground up material of the underlying shales, limestones, and sandstones, together w1th the clay and boulders brought down by the ice. Where the basal material consisted largely of shales and sandstones of the lower Carboniferous the so1l is argillaceous, but where the I1mestone predominated the t1ll became quite calcareous. This condition, together with the varying thickness of drift deposit, are of great importance in determining the character of the 8011 as w1Il be subsequently pointed out.

Succeeding the period of glaciation, there was spread over the entire glaclated area, and for a short distance to the south of 1t, a fine earth deposit known as loess. Adjacent to the Missouri and Mississippi Rivers the deposit sometimes reaches a depth of 150 feet or more, but gradually thins out away from the streams. In the northwestern part of the State it is of great depth over large areas.

The unconsolidated materials in the southeastern part of the State belong to the Tertiary and quaternary. They consist of clay, aand and grave, but are nearly everywhere covered by recent alluvium. 


\section{Topography}

The surface features of Missouri are largely the result of the underlying rocks and the agencies that have acted on them, so that the aeveral phyolographic provinces of the State colnclde with the several geological provinces. The Ozark region is not only a distinct geological province, but also represents a physiographic untt. The prairie plains of western Missourl and the glacial area of the northern part of the State each possess distinct geologic and physlographic features.

Topographically Missouri is naturally divided into four great provinces--North Missouri glacial region, West Missouri pralrle, Ozark region, and Southeast Lowlands (Plate III).

It 18 to be remembered that these provinces are not confined to Missourl alone, but that each forma a part of the larger area which extends into the adjoining states. Thus the glacial region is the southern portion of that great topographic unit including the greater part of the north-central United States. 'the western prairie region is the eastern edge of the vast sloping plain, stretching west to the foot of the Rocky Mountains. The Ozark region extends southward into Arkansas and Oklahoma. In the southeastern Lowlands are antie1pated the broad costal plains of the Southern States.

\section{North M1ssour1 Glactal Reglon}

This region, in Plelstocene times, immediately after the deposition of the glacial till, was a broad, relatively smooth 


\section{Physıographic Provinces of Missouri (Marbut)}

Missouri

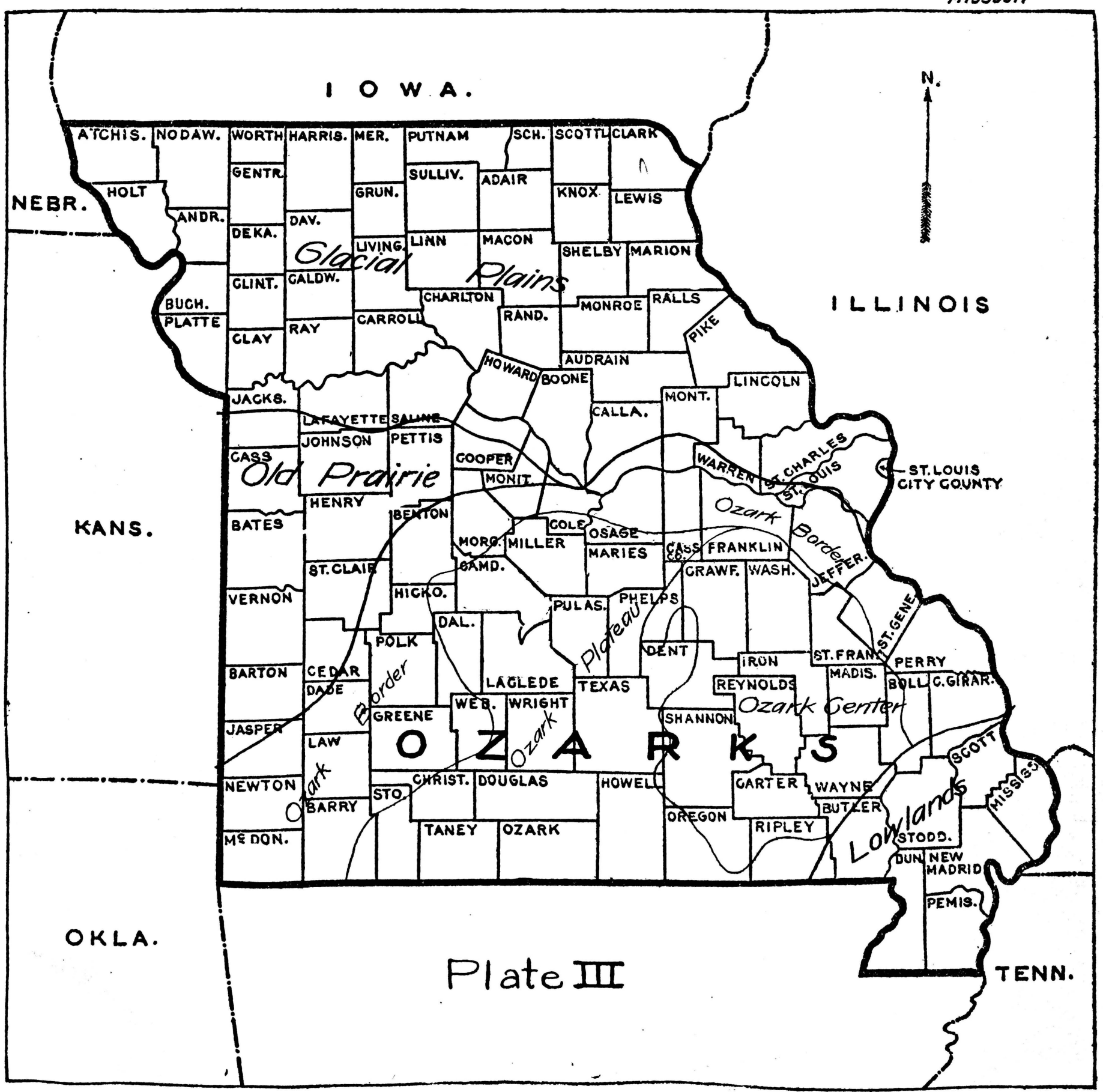


plain, sloping gently toward the south. Since that time drainage channels have been established, valleys have been eroded and widened, and tributary drainage ways developed, so that only a comparatively small part of the original plain remains 1ntact. In the eastern part of the State remnants of the anclent plain which have escaped the widespread degradation of the country may be seen in the broad divides, of which the most extensive is the flat prairie extending from Howard County to P1ke County, and from northern Callaway county to the Iowa State line. On this plain the surface is level or gently undulating, belng broken only by small dralnage channels barely sufficient to dispose of the water after heavy rains.

To the east and south this plain slopes to the Mississippi and Missouri Rivers respectively, with a maximum difference in altitude of about 400 feet from the level of the river flood plain to the level of the prairie. This slope represents the belt of rolling to moderately hilly topography that includes approximately one-half of each of the counties bordering the M1s818sippi River and of the Missouri River from its mouth to the west side of Howard County. Altho there is very little level land in this belt, very little of it is too steep for cultivation, and it is only along the larger streams and adjacent to the rivers that the topography is of the bluff type.

The level prafrie region breaks off rather abruptly to the west into a region that is rather completely dissected, so that none of the old plain remains and the surface everywhere 18 more or less rolling. The divides are mere ridges, and the streams 
have extended their tributaries to drain the entire surface. There is little of the badly dissected type, but much of it is sharply rolling, particularly near the streams. Drainage channels have been established more thickly than in any other part of the State, and there are no extensive areas that are not eroded by streams so as to give some variety to the topography. This rolling area is the triangular region having Grand River, Chariton River, and the Iowa State line as its sides.

The western part of the glacial region includes the territory between the Grand River on the east, and the Missouri River on the west. It is characterized by a gently rolling to smooth or undulating surface. It is not crossed by any large streams except in the northwest portion, and the smaller dralnage systems have cut down to only moderate depth. There are large areas many miles in extent that have a billowy surface, which insures ideal surface dra1nage. Over the greater part of this region 18 spread the 10ess, which gives the pleasing contour characteristics of this material wherever it occurs in a humid region and has not been exposed to excessive erosion. The belt of eroded country bordering the Missourl River is almost down to grade, and therefore has few slopes that are too steep for cultivation.

In general, the topography of the glacial region is constructive in origin, and the smoothness is that of new erosion. West Missour1 Prairie Region

This region represents the smoothest portion of the State, and is characterized by level to gently rolling topography. 
These features are due to the character of the rocks of the underlying formations. The latter consist largely of shales, Iimestones, and sandstones, which dip to the northwest at a very low angle. From such a structure is derived the succession of flat plains and rolling escarpments. Where the clay shale bedo prevall the country is flat; where sandstones or Iimestones prevall the hills are generally low and rounded. Where the rocks of the Upper Carboniferous occur, as in Jackson and parts of Cass and Lafayette Counties, there is very frequent alternation of limestones with shale, and the resultant surface is more rolling or undulating. In the remainder of the prairie region, wide, gentle sloped valleys, streams with gentle grades and broad flood plains, and brosd, rounded divides are characteristic. The main streams have few laterals, and have not extended their tributaries to drain the entire surface of the flat divides. In short, it is a mature topography, --a smoothness of long continued eroston. (8)

Ozark Region

The Ozark region, frequently known as the Ozark Mountains, includes all that portion of the State south of the Missourl River not included in the Weatern Prairie and Eastern Lowland regions. Its boundaries on the south, east, and north are the Arkansas State line, the Mississippl and the Missourl Rivers respectively. The western boundary extends from near the northwestern corner of Cooper County in a southwesterly direotion to the southwest corner of Jasper County. 
The region as a whole is higher and more dissected than the adjoining prairies to the north and west. It has been subjected to erosion for a long perlod of time, and has reached the mature stage of topographic development. The stream valleys are usually deep and narrow, and are bordered by belts of rough, dissected country. Only a small part of the area can be called mooth. However, the total area that 1s topographically too. rough for agricultural purposes is relatively small. (Plate IV).

The roughest part of the Ozark region as well as of the State is found in Crawford, Washington, Iron, Madison, Wayne, Reynolds, Shannon, Carter, and portions of the adjoining counties. Th1s area is frequently known as the Ozark center-not the geographic center but the geologic center. The topography varies from hilly to almost mountainous. The highest peaks in the State are located here. The valleys are numerous and deep, and may be 500 to 700 feet below the tops of the ridges. The former are mere gorges, and few of them have alluvial belts wide enough for even small farms. It is the region of the oldest rocks, the granites, surrounded by flinty limestones w1th some sandstones. The solls therefore are full of rocks, which tend to intensify the rough appearance. As a whole, the greater part of this area is non-agricultural. It is represented on the so11 map by the Clarksville stony loam.

Another area that is closely related topographically to this rugged section occurs along the Osage and Niangua Rivers in Camden County and the northern part of Dallas and Laclede Counties. 


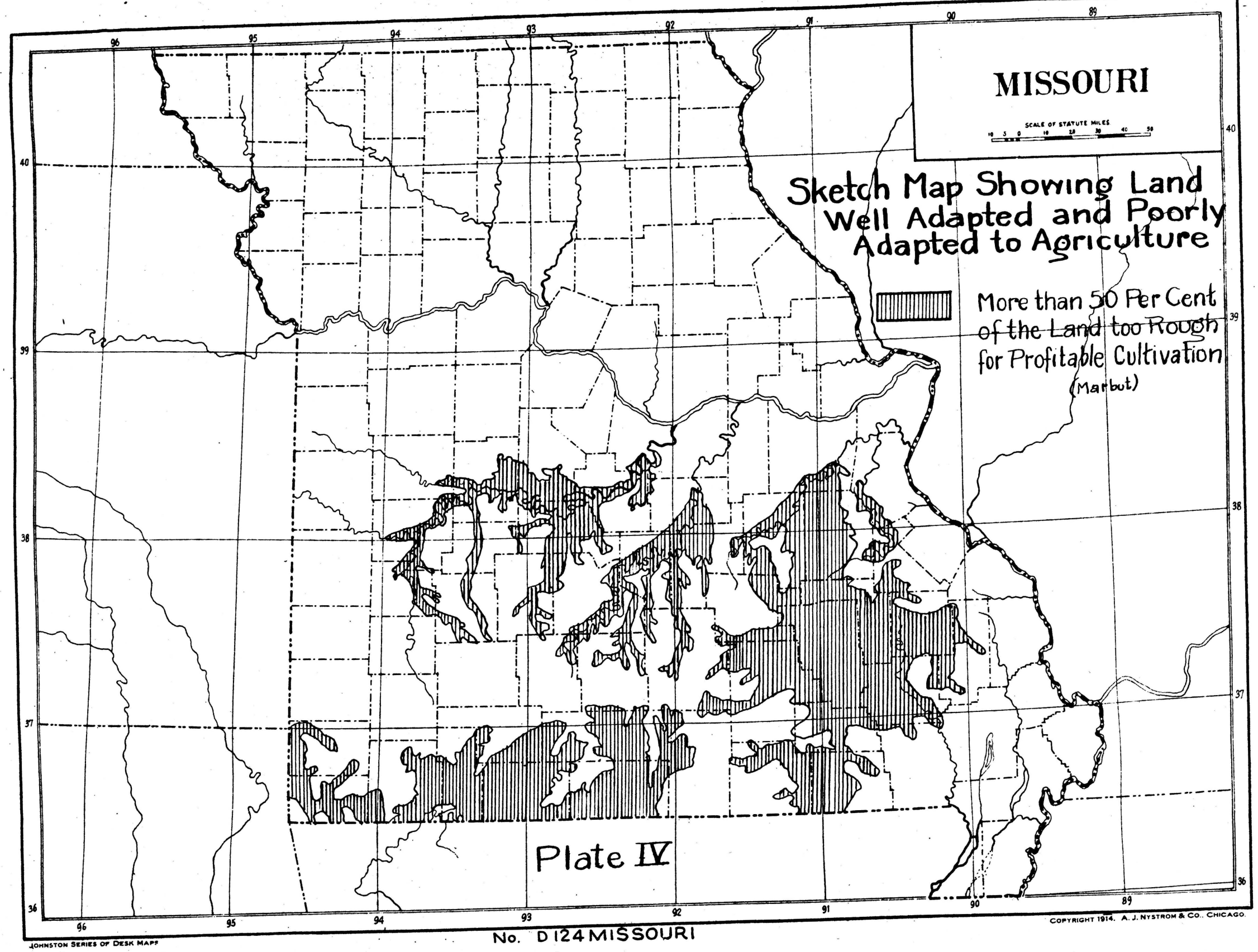


Here the dissection is complete and intricate. It is almost an uninterrupted series of narrow branching valleys and sharp ridges. The occurrence of even small areas of smooth land is 80 infrequent as to be practically negligible. Such a topography together with the large amount of stone in the soll makes cultivation practically impossible.

The central part of the Ozark region, embracing about twenty counties and extending from cole county on the north to the Arkansas State line on the south, is frequently known as the Ozark Plateau. The topography varies from almost level to hllly, the former representing the broad intrestrean divides. Extensive smooth to gently rolling areas, varying from one to ten miles in width, occur in Laclede, Dent, Texas, and Wright Counties. The St. Louls and Springfield and the Kansas Clty and Memphis lines of the Frisco railroad follow these almost level divides. The streams of this region are bordered by belts of very rough country, which gradually becomes less rugged as the higher uplands or divides are approached. In general, the southern part of the plateau region including the greater part of Douglas, Christian, Taney, and Ozark Counties, has more otreams and is more completely dissected than the northern part of the area. In fact, a large portion of this southern area is non-agricultural.

The western part of the Ozark region and that portion (approximately the width of a county) bordering the Missouri and M1so1ssippl Rivers, is known as the Ozark border. It 18 transitional between the dissected Ozarks and the level prafries to 
the north and west. It is not so rough as the main body of the Ozark region, and the solls are less stony. The topography is varled, but in general may be described as hilly to rolling. The former prevalls along the streams and rivers, while the latter includes the brosd divides and plateaus. Probably the most extensive area of rough land is in the extreme southwest corner of the State, in the drainage region of the White River. The surface everywhere $18 \mathrm{hllly}$, but the valleys are not 80 deep and have more gradual slopes than those of the region to the east. In Greene, Lawrence, and the counties to the north and west, the surface is comparatively smooth, except where minor streams have cut down to moderate depths. That portion of the Ozark border along the Missouri and M1ssissippl Rivers is rolling to hilly, but by far the greater part of it is not too steep for cultivation. The hilly areas are most extensive In Osage, Jefferson, and Ste Genevieve Counties, where the belt 1s crossed by the Gasconade, Meramec and other streams, and is completely dissected. On the watersheds between streams the relief is not so strong, the topography being neither smooth nor very rough.

\section{Southeast Lowlands}

The Southeast Lowland region is one of the most pronounced physlographic areas of Missour1. It is the northern extremity of that vast lowland region extending thru Arkansas and Loulslana to the Gulf of Mexico, known as the Mississippl Lowland. In Missouri the boundaries of this region are clearly defined. It 1 s set off from the ozark region by a distinct bluff line, 
varying from 25 to 150 feet in height, and extending from Cape Girardeau southwestward to the State line in southeastern Ripley County. The lowland region as a whole is a broad flat plain, with a gentle slope to the south. With few exception the surface variations are not more than ten feet, which explains why large areas have poor surface drainage. The two prominent features of the Lowland are Crowleys Ridge and Commerce Hills, remnants of an old upland, that stand from 20 to 150 feet above the level floor of the general plain. The east and north slopes of these ridges are abrupt, but to the west they grade off imperceptibly into the lowland. Crowleys Ridge varies in width from one to fifteen miles, being widest in the northern end. Like the Commerce Hills, it is completely dissected, and in its general surface features resembles the uplands to the north. Sikeston Ridge is a low, inconsplcuous ridge standing about 25 feet above the adjoining bottoms, and extends from Commerce Hills southward to New Madrid.

\section{Altitude}

The greatest altitude in Missour1 is about 1800 feet, attained by a few peaks in Iron County in the Ozark center region. Here also occur the greatest variations (500 to 700 feet) In altitude for a given area. In general, the average altitude of the Ozark region as a whole, is about the same as the average altitude of northern Missouri (Plate $\Psi$ ). The highest portion of the Ozark region is the extensive plateau or Ozark Divide, which extends from St. Francoir 


\section{Contour Map of Missouri Contour Interval - loofeet \\ (Marbut)}

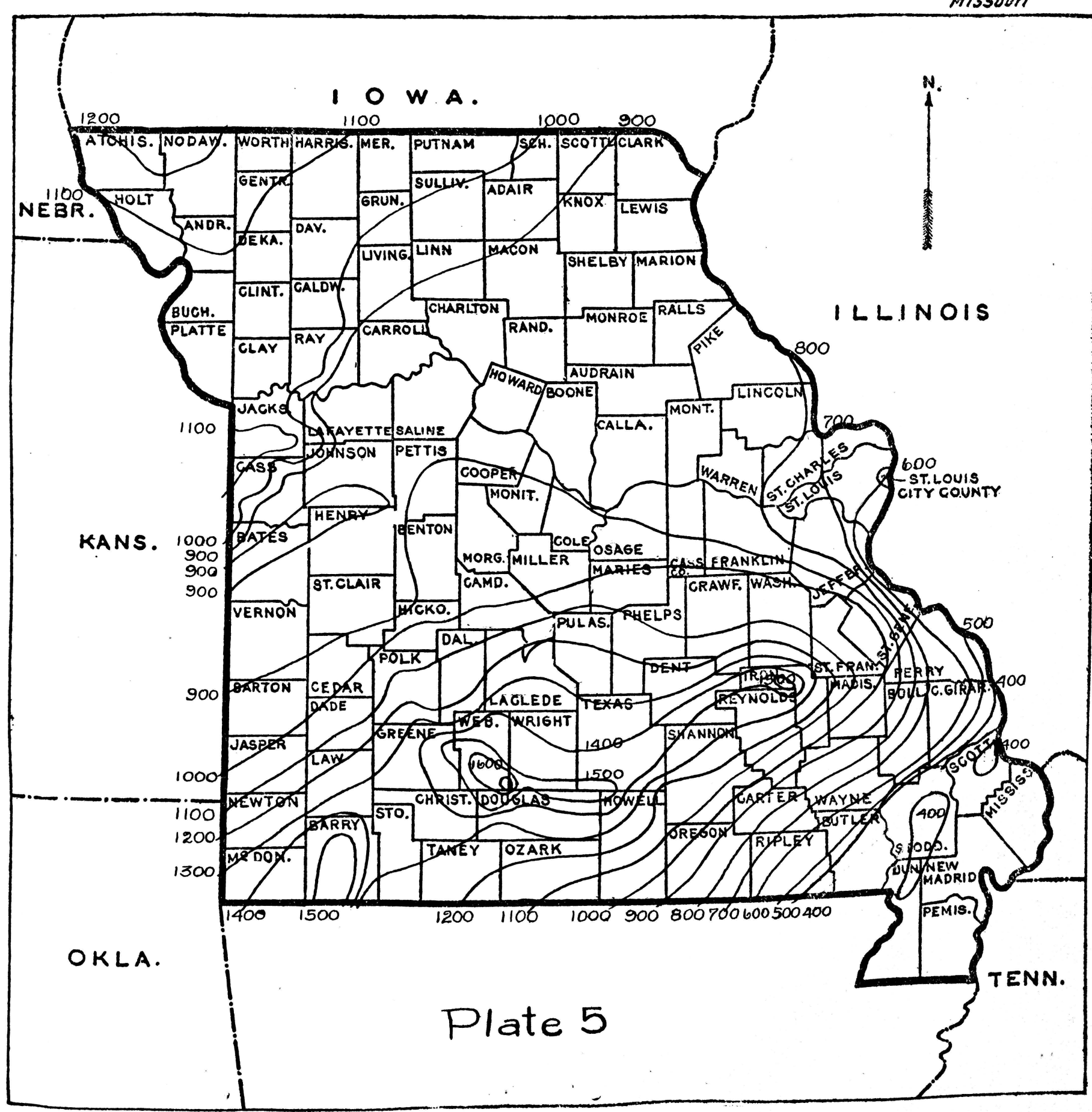


County southwestward to the Arkansas State line in Barry County. In St. Francols County it is about 1100 feet above tide level. In Iron and Reynolds Countles it is about 1600 feet. There Is then a gradual fall to 1400 feet in Dent County, where there is a large area of flat upland lying at about this altitude. In the eastern part of Wright County the height increases to 1700 feet, but thence southwestward near the State line in Barry and Taney Counties there is a decrease in elevation to about 1550 feet. This Divide is surrounded on the north, east, and south by a broad marginal zone, deeply trenched by water courses, that decreases gradually in altitude unt1l the lowlands bordering the Missour1, Mississippl, and White Rivers are reached. The alt1tude of North Missouri varies from about 800 feet, fronting the Mississippi River, to 1200 feet in the extreme northwestern corner of the state. This variation is characterized by a gradual rise in the elevation northwestward. The central part of the resion lies near the 900 and 1000 feet contour levela. The west Missourl prairie region has about the same altitude as North Missouri, and like the latter lo lowest in the eastern part and highest in the northwestern part. The rise 18 at the same rate as that north of the Missouri River, and reaches an elevation of about 1150 feet on the high prairies of Cass and Jackson Counties.

The lowest elevation in Missouri is about 290 feet in the extreme southeastern corner of the state. The average altitude of the southeast Lowlands varies from 300 to 350 feet, the higher areas occurring in the northern part of the region. 


\section{SOILS}

\section{General Description}

The term SOIL in its broadest sense, refers, with few exceptions, to the unconolidated mantle of disintegrated and more or less decomposed rock powder together with more or less organic materlal, which, under favorable conditions, will support the growth of plants. As it is only the surface portion of this material that concerns the agriculturist most, it has become a common practice to apply the term 'so1l' to the surface material that has been darkened by organic matter, while the underlying part is termed sub8011. In general, the depth to which the bulk of the roots of grasses and small grains penetrate marks the depth of the soll or surface soll. In the case of many alluvial so1ls the surface so1l may extend to a depth of two, three, or more feet, but on the uplands it will probably not average over twelve inches in depth. The subsoll is usually lighter in color and more compact than the surface soll. This is primarily due to a lack of organic matter and to filtration of clay. An Increase of the surface soll may be secured by gradually increasing the depth of plowing, thus permitting the deeper incorporation of organic matter and the action of alr.

In many so1ls, generally those of a level topography, the surface soll and the subsoll are separated by a layer of material that possesses distinct characteristics and is easily distinguished from the so1l above and below. This 
layer is called subsurface. It may vary in thickness from one to several inches, but rareiy exceeds twelve inches. In texture it 1s usually like the surface so1l, but in color it more nearly resembles the subsoil. In such cases where the lower subsoll consists of gravel or coarse atone, the finer material above is frequently considered as subsurface, but unless this material differs from the fine material in the lower stratum it is usually classed as subsoil. At some experiment stations it has been customary in sampling soils to consider the top 7 or 8 inches as soll, the layer from this so-called soll down to 20 inches as subsurface soil, and from 20 to 40 1nches subso1l. The Mlssouri Experiment Station is following the practice of deslgnating the surface 7 inches as soil, the layer from 7 inches down to change in color as subsurface soll, and from change in color to 36 inches as subsoll.

All soll descriptions in this thesis apply only to the upper three feet of soil material, and the lower substratum 1s referred to only when it possesses such pecullar characteristics as might affect in some speclal way the growth of plants. This arbitrary depth of three feet is adopted because the substratum is usually simllar in its characteristics to the lower subso1l, at a depth of 36 inches, and a description of the latter also will apply to the former. 
Soll Classification

By virtue of the great varlation in geological formations and conditions, and the rezultant variable topographic features, the solls of Missourl present extreme varlations in their varlous characteristics. However, a study of these varlations will show that certain regions possess certain similarities and when such similarities have a well defined relation they form a basia for grouping the solls. In general, the nature of the solls of a given region is intimately related to the klnd of bedrock from which they have been derived and to the particular processea by which the rock has been disintegrated and deposited in 1 ts present position. Thus the solis of the Ozark region have relationship in that they are derived from limestones, and almost universally contaln more or less gravel; the solls of northern Missouri have the cormon characteristic of being glacial in orlgin or the result of glacial action. In brief, simflar geological causes w11l result in the solls having marked peculiarities. It is therefore on the basis of their origin, topography, and mode of formation that the so1ls of Missourl are divided into four great groups or provinces, these provinces colnciding with the four physlographic diviolons of the state.

The solis of each of these provinces are divided into several group according to the source of the material and the agencles by which 1t was accumulated: Thus the solls 
from the pure limestones make a separate grous from the s0110 of the moderately cherty Iimestorea; the solis of aecliar. depositior are grouped separately from those of glacial deposition. It has been found that by this grouping soils closely related from a geclogic standpoint also have close relation from an agricultural standroint.

Based on the physical properties of the so11, such as color, texture, content of organic matter, etc., these groups are divided into one or more series, and they are designated by giving them locality names such as Shelby so1ls or Eates so11s. To each series name are added the descriptive terms of the soll class, such as Shelby loam, Bates fine sandy loam. The soil unit is the so1I type. It is uniform in a.1 the above characteristics in all places where it is found. This classification of soils is according to that in use by the U. S. Bureau of So12s.

All soll areas that are essentially the same in their characteristics and properties have been included in the same soli type. It is to be rememered, however, that variations in the productiveness due to different treatments are not a basis for separating oolis into types. It is only the inherent or static fertility, or the characteristics that do not undergo great changes that are considered in soll differentiation.

In a reconnalssance it is not possible to make as fine separations as in a detalled survey, and the material mapped 
as a type must ecessarily often include wider variations in character, and many small areas of other types have to be shown in one color on the map. In general, the soll types in the northern and western part of the State are more uniform or contain fewer variations than the soll types of the Ozark region. This 18 due to the fact that the soll forming material and soll forming agencles have been more uniform over large areas in the former regions than in the latter region.

The change from one soll type to another is usually a gradual one, and frequently extends over a considerable distance. Bottorland types are set off from upland types by distinct change in topography, but division between upland types is not so apparent. It is to be remembered, further, that in a reconnalssance survey the soll boundaries can not be as accurately drawn as in a detalled survey. In using a soil map these, as well as other limitations, should be understood and due allowances made. 


\section{Clasification of Missourl Solls}

So11 Province

Loespial and

Glaclal

Residual Plains

Solls of

West M1ssouri
So1d Groups and Types

Solls from loessal deposits

Knox silt loam

Marshall silt loam

Grundy silt loam

Putnam silt loam

Solls from glacial deposits

Shelby Ioars

Indley loam

Alluvial soils

Wabash loam and clay loam

Solls from limestone and shale

Surnmit silt loam

Soils from shale

Oswego allt loam

Cherokee silt loarn

Solls from sandstone and shale

Bates fine sandy loam

Alluvial soils

Osage silt loam 
Soil Groups and Types

Solls from pure limestone

Hagerstown silt loam

Soils from moderately cherty limestonee

Union silt loass

Crawf ord gravelly losm

Lebanon silt loam

Solls from limestone, sandstone, and shale Tilait silt loam

Ozark Region

Boone loam

Solls from cherty limestone

Clarkaville gravelly loam

Clarksville stony loam

Solls from grante

Ashe stony loam

Alluvial soils

Huntington loam

Southeast

M18sour1

Lowlands

Alluvial solls

Sarpy fine sandy loam

Lintonia silt loam

Lintonia fine sandy loam

Sharkey clay loam

Waverly silt loam

Waverly fine sandy loam 
Glacial and Loesdal So118

The glacial and loespal soils include, with few exceptions, all the northern part of the State north of the Missouri River, and several limited areas south of the river. The latter are most extensive in Saline, Lafayette, Jackson, and St. Louls Counties, with smaller areas bordering the valley of the Missouri and Mississippi Rivers. In total area, the glactal and loessal province covers approximately one-half of the State.

The general surface features of the province are that of a plain, with a gentle slope to the south and east. Bordering the large streams and their tributaries is a belt of rolling country, so that only a small part of the original level plain remains. The latter is represented in general by the Putnam, Grundy, and Marshall so11s. Excepting a very narrow belt forming the bluffs or river hills bordering the Missourl and M1ssissippl Rivers, the topography nowhere can be described as hilly. In general, the surface is level to gently rolling, and practically everywhere permits of the development of the highest type of agriculture. Non-agricultural land in this province is so small in extent as to be of negligible importance.

In their original condition the glacial and loessial solls of northern Missourl formed a vast prairle, broken only along the larger streams by narrow bands of timber. All the level and rolling land was covered by a dense growth of prairle grass. The steeper slopes bordering stream valleys, and many of the 
bottom lands had a growth of oaks, elm, hickory, and walnut. The trees were large, and were not so close as to exclude the growth of grasses between them. Practically all of the original prairie grass has long since disappeared, and only small areas of timberland remain.

In general, the glacial and loessal soils of northern M1ssourl are characterized by their remarkable uniformity over large area, by high fertility and prevailingly dark color.

\section{Loessíl So118}

In the chapter on geology is described the orlgin of the extensive areas of aeolian soils commonly known as Loess. After the deposition of the till by the glaciers, there was spread over the entire region and for a short distance to the south, a fine dust materlal that gave rise to the loess. The deposit was thickest near the Missourl and Mississippi Rivers, and gradually thinned out away from the streams. In this report only those solls are classified as loessal which are derived from material that is generally accepted as aeolian in origin.

It is a significant fact, and is indicative of its origin, that the loess solls in Missourl occur only along the Missour1 and Misissippl Rivers, and have their greatest distribution where the flood plain of these streams is widest. The largest areas of loess soll occur in the northwestern part of the State, where the maximum width of the belt is 
approximately fifty miles. To the east of Kansas City the belt gradually widens, attalning its greatest width near the longitude of the west line of Saline County, when it again rapldiy narrows, so that from Boonville to st. Charles it occurs as a broken belt varying from one to six miles in width on both sides of the river. Along the Mississippi River the loess belt extends from the northern part of Marion County to the Arkansas State line, reaching its greatest width in St. Louls County. It does not cover the entire surface in the region of its occurrence, altho along the Missourl River it covers the entire surface excepting the bottom land and some of the steeper slopes from which it has been washed down to lower levels. The loess solls are found in forty-five counties, and cover approximately ten thousand square miles, or thirteen per cent of the State.

Loess rarely or never contains gravel or coarse sand; neither does it contain a very large per cent of clay altho it 1s fine textured. The soll particles are of such size as to be classed as silt, and this character is the one to which the loess really owes 1ts value as a soll. It is an almost 1deal texture, the porosity of which is such that it easily rids itself of excess water and yet it is enabled to hold sufficlent molsture for growing crops.

The soll particles are coated, more or less, with oxide of 1 ron and calcic carbonate. The amount of the former gives color to the soll whlch, in the typlcal form, is usually a 
light buff or dull reddish brown; when absent the color is graylsh, sometimes approaching white. The removal of the Iron oxide probably results from the oxidation of decayed vegetation which changes it to a carbonate, in which form It leaches out, or collects in the form of concretions in the subso1l. This phenomenon is especially marked near the margin of the loess where it is shallow, or in places where 1t has been reworked by wāter.

The presence of the calcium carbonate together with the clay appear to constitute a cement which holds the so1l particles firmly together so that the loess stands firm like indurated rock, unless softened by moisture. The presence of the lime also tends to make the soll retentive of organic matter, and explains why the loess solls under favorable conditions usually contain a large per cent of this material. Lime concretions and calcarious fossils are scattered thru the soll where the deposit is thick.

That portion of the loess solls lying adjacent to the river valleys has been subjected to excessive erosion, and the consequent rolling surface has not been favorable for the accumulation of organic matter. In general, too, the eroded portion has a somewhat coarser texture than the more level areas. Based on these characteristics, the looss solls have been separated Into two types, Knox silt loarn and Marshall silt loam.

Knox S1lt Loam

The Knox silt loam represents the light or brown colored 
and eroded portion of the loess. Along the Missourl River it occupies the river hills and rolling areas adjacent to the stream, but along the Mississippl River it includes the entire area of the loess deposits.

The surface s011 to an average depth of ten to fifteen Inches is a brown to yellowish-gray silt loam. The color is varlaicle, and is usually a brown or dark gray on the well drained areas where erosion is not excessive. On areas deficient in organic matter as on steep slopes and poorly drained flats the lighter shades of gray and yellow prevall. The subsoll is a light brown or pale yellow silt loam, usually becoming more clayey in the reglons farthest away from the river bluffs, and extending to the bottom of the loess material without any appreciable change. It can be said that the so1l of the Knox silt loam has no true subsoll; the former is merely the upper part of the loess deposit more or less darkened by organic matter. In the lower substratum fosil snall shells and potato shaped concretions are found.

In general, the texture of the Knox silt loam is coarser nearest to the river and finer away from the stream. This characteristic is most pronounced in the rorthwestern part of the state, where the soil on the river hills is almost a fine sandy loam. Along the Mississippl River the type averages heavier in texture, especially in the subsoll, than the Missouri River loess. This condition may be explained by the fact that the prevailing winds in the northwestern part of M1ssourl are stronger than in the eastern part and can there- 
fore carry coarser material. Coffey $(9)$ found that the so1l grains of the Missourl loess are mostly angular, with some fairly well rounded, while in the M1s8lssippi loess the gralns are mostly well rounded, with a few angular. The latter represents material which was transported much farther and has therefore been subjected to more abrasion and decomposition. Along with this fact it is interesting to note that the knox silt loam in the western part of the State is more calcareous than along the Mississippl River, which in turn probably explains the greater amount of organic matter in the soil of the former region than in the soll of the latter region. AssumIng that the loessal soll was taken from the valley of the large rivers, this variation in the composition of the Knox silt loam can be explained as follows: The Missourl River, flowing at a rather steep gradient and draining a semi-arid region, will naturally carry rather coarse and only partially leached material. The soll derived from this material whlch indirectly gave rise to the loess in the western part of the State will therefore possess many of the characteristics of the parent material. The Hississippi River flows at low gradient thru a region of fine earth and relatively high humid1ty. Its sediment therefore will consist of fine material more or less leached. The loess soll formed along this stream will therefore be of corresponding fine and leached material and thus differ from the Missouri River loess. Again, the Knox silt loam in the southeastern part of the State is heavier in texture, lighter in color, and has a more leached appearance 
than along the upper Mississippi. This condition, in addition to the facts above explained, may be due to the greater age and to the more active agencies of weathering that prevail in this part of the State.

The Knox silt loam possesses a high degree of potential fertility with regard to the mineral elements. Its physical properties also are highly favorable. The internal drainage is good, and aeration and caplilarity are effective thruout the oll section--three feet--and to a depth in the underlying strata. This must appreaciably improve the conditions in the surface layer in which the roots of plants find nourishment.

In general, the Knox silt loam is deficlent in organic matter. This is especially true on the eroded areas and in old fields that have recelved insufficient care. If it is not.properly handled it deteriorates. On the other hand, it is readily susceptible of permanent improvement, enabling it to produce large crops.

The topography of the Knox silt loam varies from hilly to rolling. The former prevalls along the rivers, where it includes the bluffs that rise from fifty to three hundred feet above the bottom lands. These rough belts usually border both sides of the river valley and extend back for a distance of one-half to three miles, and are cut by deep tributary valleys, giving a region of steep slopes and eroded surface. Back from the bluff land the surface is universally rolling 
without any areas of level land. The total area of the type that is too broken to permit cultivation is very small. The silty texture of the soll alded by the rolling surface causes erosion to be rapid and very destructive. Cullies formed are usually deep with perpendicular walls. Cuts fifteen to thirty feet deep are common near the rivers, and frequently are made in one season. In brief, the rolling surface and excessive erosion are the limitations in the use of this soll. (Plate VI).

Practically all of the Knox silt loam is occupled for agricultural purposes. All the staple crops common to the State are grown successfully on 1t, and as a fruit so11 it is unexcelled. Where the surface is not too rolling most of the type is used for corn and wheat. Yields of from forty to sixty bushels of the former and of twenty to twenty-five bushels of the latter per acre are common. Clover and alfalfa thrive exceedingly well, which is resulting in the more wldespread occupation of the type for the production of these crops. The steeply rolling land is largely used for grass and pasture. In the southeastern part of the State cotton 1s grown on the Knox s1lt loam*. In St. Louls and Jackson Counties large areas are used for trucking. Large commerclal orchards have also been set upon this so11. The trees make good growth, and come Into bearing at an early date. An excellent quality of fruit is produced.

*The loess in southeastern Missouri has been correlated with Nemph1s s1lt loam.by U.S. Bureau of Solls. 


\section{Soll Erosion Map of Missouri}

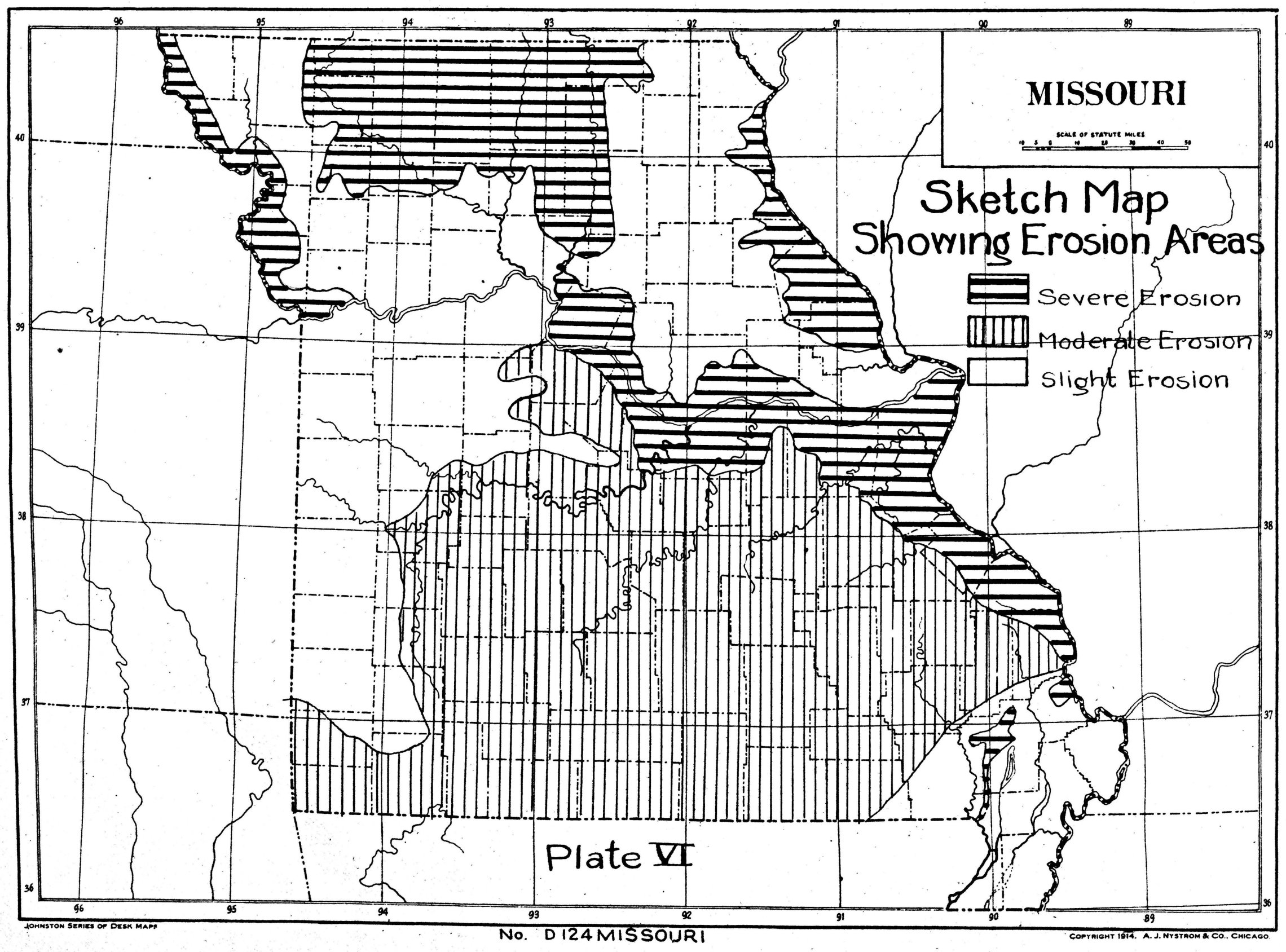


Chemical analys18(a) --Knox silt loam

\section{Total Total Total Lime Nitrogen Phosphorus Potassium Requirement $(b)$}

M1ssour1 P.1ver Area

$\begin{array}{rlllr}\text { S011 } & 2660(c) & 1206 & 33,373 & 0 \\ \text { Subs011 } & 1506 & 1113 & 27,710 & 960\end{array}$

Mississippl River Area

$\begin{array}{rrrrr}\text { So11 } & 1894 & 1268 & 34,006 & 1036 \\ \text { Subs011 } & 896 & 1540 & 33,146 & 2615\end{array}$

Th1s data does not permit the drawing of any definite conclusions, but it seems to agree with the statement previously made that the Knox silt loam is more calcareous and contains more organic matter in the western part of the State than in the eastern part.

\section{Marshal1 S1It Loam}

The marshall silt loam constitutes the most important and probably the most extensive single soll type found within Missour1. Like the Knox silt loam, it is of loessal origin,

(a) All chemical analyses included in this thesis were made by the Department of Agrioultural Chem1atry, Univeraity of Missouri. The soll samples used were the offlcial samples taken in connection with the soll survey field work.

(b) Ve1tch Method.

(c) Results are given as pounde per acre in $2,000,000$ pounds of so11. 
and has its widest distribution in the western and central part of the state. Thruout the region of 1ts occurrence It occuples practically all of the upland soll.

The surface so11 of the Marshall s1lt loam consists of a dark brown to black, mellow, sllty loam, containing a large amount of organic matter. In depth it ranges from ten to twenty inches, the shallower soll prevaling on the roling areas and the deeper soll on the more level prairles. The subso1l from twenty to thirty-six inches is a brown, dark drab or yellowloh brown silt loam or silty clay. loam. Th1s material normally extends to a depth of six or elght feet, tho 1t may possess a total depth of fifty or one hundred feet over wide areas. Frequently in the lower portion of the three-foot section there 18 present less clay and more silt than in the upper subso1l, and the structure is more friable. In many cases the surface soll feels slightly heavier than the subso1l, but this is due to humus rather than to a hlgher content of clay. In general, the soll and especially the subsoll are heavier near the outer margin of the type, and lighter where the type borders on the Knox allt loam. In the subso1l are found concretions and accumulations of lime carbonate and calcareous remains of shells.

On the whole, the Marshall silt loam represents a thinner deposit of loess than does the Knox silt loam. On the steeper slopes, especlally toward the outer margin, outcrops of the underlying t1ll are much in evidence, and a part of the soll is undoubtedly of glacial origin, altho it was not 
possible to show the areas as such on the map.

The topography of the Narshall silt loam is undulating to gently rolling, with generally just enough slope to Insure good drainage without inducing excessive erosion. The rounded, blllowy, rather smooth outline of the slopes is one of the most characteristic and pleasing of the contour features. In addition to good surface dralnage, the 100se, frlable subsoll insures good under-drainage except In a few flat depressions. Many such areas have been t1led, and have been found to be even more productive than the higher ground. The cost of artificial drainage 1s 10\%, since the ditches are easily dug, and in the majority of instances only a single line of tile lald thru a depression or draw is necessary to remove the surplus molsture. In all of 1ts physical properties the Marshall silt loam 1s almost an 1deal so1l. The gentle slopes, the excellent texture and structure, and the great depth of the so11 with a high content of organic matter, tend to make this type one of the most productive and valuable solls in the State. Moreover, the soll $1 \mathrm{~s}$ well supplied with lime. The lower subsoll and the substratum are calcareous and effervesce with acid. In fact, many borings in this type give an effervescence with ac1d within three feet of the surface, but seldom nearer the surface than elghteen inches. Conslderable of the surface so1 18, however, beginning to develop acldity as shown by lime requirement determinations, altho the relatively high content of lime no doubt acoounts for the high per 
cent of humus in the soll. Moreover, the presence of conolderable organic matter indicates that the so1I is pretty well supplied with readily soluble plant food constituents. The importance of these characteristics can not be overestimated, since they are largely responolble for the high fert1ilty of this so11 type.

The Marshall silt loam is the dominant corn 801 of the "corn belt". Counties princlpally covered by this soll are the premier corn counties, and the ylelds obtalned average higher than for any other upland type. Ylelds range from 35 to 90 bushels per acre. All the crops sulted to the cllmate and to a s1lty so1l grow well. Thus oats, clover, alfalfa, timothy, and fruit thrive exceedingly well and give high average ylelds. The ylelds of oats per acre are usualIy about the same as those of corn, and range from 40 to 80 bushels. Wheat is not quite so well adapted to this land as are corn and oats, but when properly handled it ylelds very good crops.

The prevaling type of farming is that of corn growing and the feeding of cattle and swine. Practically all the grain ralsed is fed to beef cattle. The mixed timothy and olover hay is ut1lized as roughage in the feeding ration, and frequently the areas in grass are pastured during the final year before the sod is ultimately plowed for corn production. Commercial fertilizers as yet are little used.

Probably no other so1l in the state bears such a high proportion of tilled and cultivated orops. (Plate VII) 


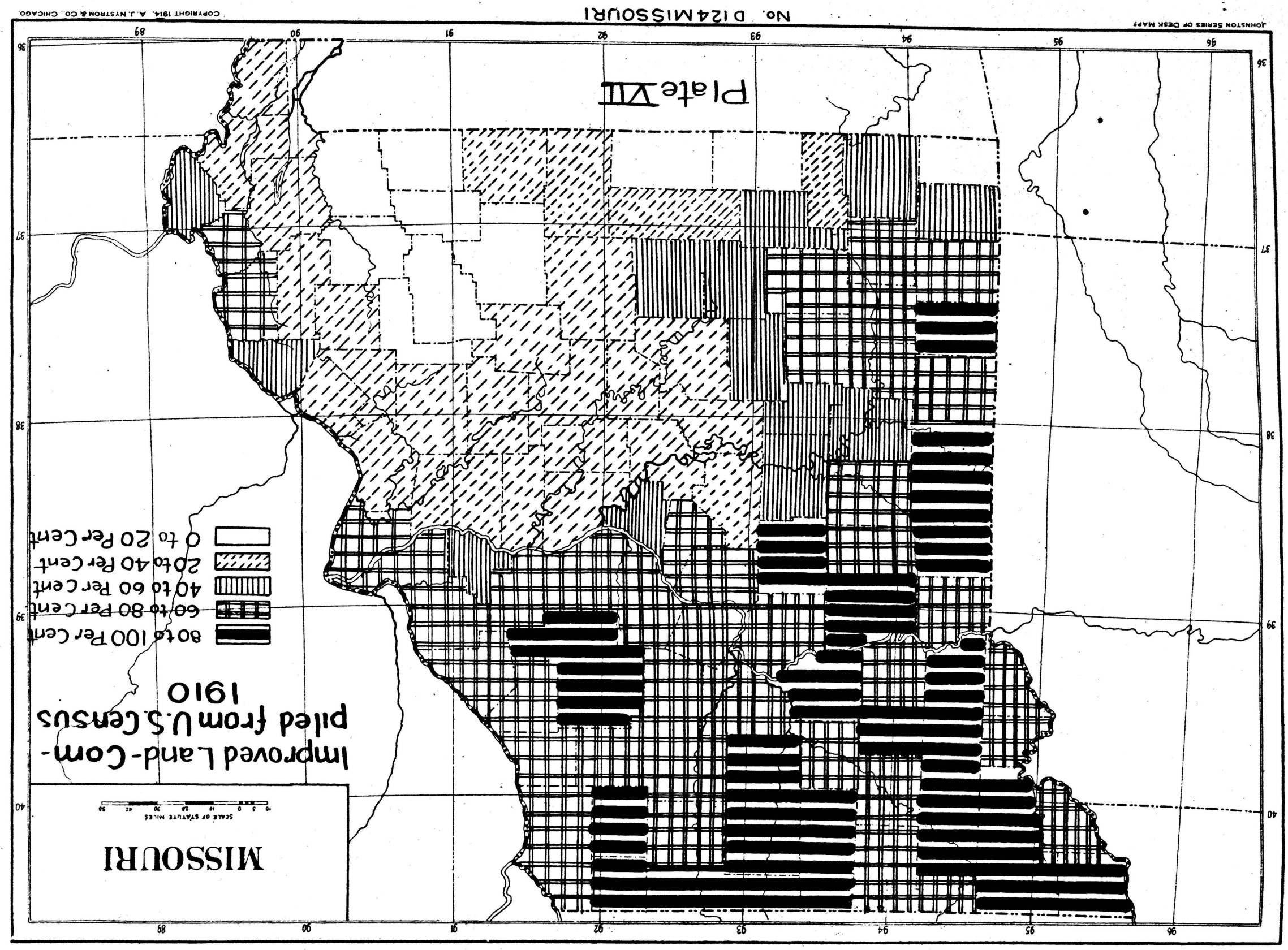


of the type may be classed as highly improved land. Farm bulldings are characterlotically substantial and well kept. The farm untts are relatively large, probably averaging 150 acres. A larger per cent of the farms are operated by tenante than on any other soil type ( 8 per cent more than on glacial so11s).

Chemical composition--Marshall silt loam

$\begin{array}{lcccc}\text { Notal } & \begin{array}{c}\text { Total } \\ \text { Nitrogen }\end{array} & \begin{array}{c}\text { Total } \\ \text { Phosphorus }\end{array} & \begin{array}{c}\text { Iime } \\ \text { Potassium }\end{array} & \begin{array}{c}\text { Requirement } \\ \text { S011 }\end{array} \\ \text { S611 } & 1822 & 33,774 & 3646 \\ \text { Subo011 } & 1914 & 1794 & 31,394 & 1938\end{array}$

As has been previously stated, a silt covering was opread over the glacial till after its deposition. This covering has not been recognized universally as a geological equivalent of the losss, altho careful study falls to find a clear demarcation between the typlcal loess near the large rivers, and the heavy silt more remote from the otreams. Probably the most pronounced difference is the finer character of the silt deposit, or "loamy clay" as it is frequently called. In the western and northeastern part of the region of 1ts occurrence this material is universally of a dark color at the surface, and ranges from three to elght or more feet in depth. In the eastern part of the state 1 usually has a gray surface color, and rarely exceeds three or four feet in depth. 
Based on these two 1mportant differences, it gives rise to two so11 types--Grundy silt loam and Putnam s11t loam.

\section{Grundy Silt Loam}

The surface soll of the Grundy silt loam consists of a black to dark brown mellow silt loam to an average depth of twelve inches. When dry the so1l has a somewhat Ilghter color and has a dark gray cast. In general, the level areas, and that part of the type found in the northeastern corner of the State are distinctly lighter in color than the main body of the so11 in western Missourl.

The upper zone of the subso11, extending to an average depth of about eighteen inches, is a dark gray to gray-brown friable, heavy silt loam or light silty clay loam. Below thls stratum is found the dark drab or yellowloh brown heavy tenaclous silty clay or clay. The deeper subsoli from about thirty to thirty-81x inches is a moderately friable silty clay loam predominantly yellowlsh gray in color, with brown, gray, and yellow mottlings. Brown iron stains and small lron concretions are present in small number thruout the subsoll. 00casionaliy lime concretions are present. However, they are not as numerous as in the corresponding strata of the Marshall silt loam.

Practically all that portion of the type found in the northeastern part of the state possesses characteristios which make it an 1ntermediate phase between the typical s01 and the Putnam s1lt loam. The surface s11t layer consists of two 
zones forming soll and subsurface. The former is dark. Iike that of the main type; the latter is gray or light gray, mealy material, varying in thickness from two to six inches, and is essentialiy the same as the gray layer in the Putnam soil. In 1ts agricultural value this phase is almost equal to the Grundy silt loam and has therefore been inciuded in the latter.

The Grundy silt loam very closely resembles the residuary Summit s1lt loam of the lower Carbonfferous areas. It also closely resembles the Marshall silt loam. Altho the Grundy and Putnam silt loams are of the same origin, the former shows much better evidence of being of loessal origin. The fact that the loamy clay, of which the Grundy silt loam is the surface expression, 1s of great thickness like the loess deposits, and the fact that the main body of this material lies adjacent to the loess, and like the latter 1s more or less calcareous in the subso1l, points strongly that it is similar also in origin. On account of the greater depth of the deposit it has not been leached to as great an extent as the Putnam silt loam, and therefore contains a relatively larger amount of plant food and Iime than does the latter type.

Originally the Grundy silt loam was covered with a rank growth of wild prairie grasses. This condition together With the level surface, the fine texture of the s011, and the presence of lime, favored the eccumulation of a large amount of organlo matter to a great depth.

Topographlcally, the type occuples the broad almost level 
divides and the gentle slopes. In general, the surface averages smoother than for the Marshall silt loam, altho this difference is of no appreciable importance. There is usually oufficlent slope to carry away the rainfall, even on the more level areas.

In every respect except the matter of underdrainage, the better phasesof Grundy silt loam is a nearly perfect soll for general farming. It 1 s friable, well drained and contalns a large amount of organic matter. The heavy subsoll rarely has any infurious effect on plant growth.

All of the type is in a high state of cultivation, and is used for the production of all the staple crops common to the region. Corn is the most extensively grown cereal, and yields of 30 to 70 bushels per acre are obtalned, running somewhat lower than on the Marghall silt loam. Wheat and oats do remarkably well, but are not as extensively grown as on the 10ess s0118. Much of the type 1s in sod, and the excellence of the blue grass pastures is not excelled in any part of the Stato. Highly improved farms and farm equipment are characterlstic of the regions where this soll occurs extensively.

Chemfcal analys18--Grundy s12t loam

\begin{tabular}{|c|c|c|}
\hline $\begin{array}{l}\text { Total } \\
\text { Nitrogen }\end{array}$ & $\begin{array}{c}\text { Total } \\
\text { Phosphoru }\end{array}$ & $\begin{array}{l}\text { Total } \\
\text { Potasalum }\end{array}$ \\
\hline
\end{tabular}

$\begin{array}{lllll}\text { So11 } & 4205 & 1806 & 28,290 & 5215 \\ \text { Subsurface } & 2068 & 1734 & 27,340 & 4540 \\ \text { Subs011 } & 1694 & 1874 & 27,530 & 1864\end{array}$


The content of nitrogen in the surface so11 is high, but decreases rapldiy downward. The supply of phosphorus is about the same as in the Marshall silt loam. The total amount of potassium is rather low in comparison to the other elements, and when the fineness of the soll material is considered. The high Iime requirement is indicated also by the consistent, tho not large, returns obtalned from the use of ground limeetone $(10)$.

\section{Putnam S1It Loam}

The Putnam silt loam 18 represented by the extensive areas of level prairie land in the eastern part of North Hissour1.

The silty surface soll to a depth of elght to twelve Inches varies in oolor from light ashy gray to dark gray when dry, to dark brown or almost black when wet. In flat and poorly drained areas the lighter colors predominate, while in areas of deep soll and good drainage the color is darker, due to the presence of a larger accumulation of organ10 matter. The texture is unformly a allt loam, whioh normally consists of seventy to eighty per cent of silt.

The surface so12 18 underla1n by a layer of gray to almost white, powdery, siliceous silt loam contalning (especialIy in lower portion) numerous small conoretions of hydrated 1ron oxide. In some instanoes this layer is almost a foot thlok, but occasionally it is only faintly dereloped. The 
deeper subso1l, beginning abruptly at about elghteen inches, consiats of a grayloh brown or dark brown otiff, Impervious clay, wh1ch grades at about twenty-four to thirty inches Into yellowish gray or drab friable silty clay, mottled red, brown, and gray. These layers, altho differing in thickness, are invariably encountered in this type, in the order given. In general the subsoll is darker in color and more intractable on the poorly drained areas.

The Putnam silt loam is easily distinguished from the other solls of the region in which it occurs by the gray colored surface so11, the gray ashy subsurface, and the almost universal presence of the stiff clay or 'hardpan'" subso11. It differs from the Grundy silt loam in the more level topography, lighter colored surface soll and the more abrupt change from the ourface silt layer to the clay sub8011. Also, the light colored, friable lower subsoll extends higher in the Putnam so11.

It has already been polnted out that both the Grundy and Putnam types are derived from the s11ty layer over t111, and that this layer is thinner in the Putnam soll than in the Grundy so1l. This fact may partially explain why there 1s a greater accumulation of clay in the subsoll of the Putnam than in the subsoll of the Grundy type. However, the differences between these two types are due largely to a difference in dralnage. The water, standing on the level Putnam s11t loam sometimes for several days after a rain, prevents aeration, so that the natural processes are entirely differ- 
ent from those which are active where the surface is rolling and the soll aerated. Under these intermittent wet and dry conditions there is always a tendency for solls to assume a gray color. According to Hilgard(11) this is due to organio acids which 'reduce the ferric hydrate to ferrous salts, oxidizing away the humus, and accumulating in the form of inert concretions most or all of the lime, 1ron, and phosphorio ac1d of the s011 mass''. While this may not be the true explanation it 18 observed that on the outer margin of the type, where the dralnage is good, the soll 18 dominantly darker in color and contalns a larger per cent of organic matter. The so11 on which the experimental flelds at Columbla are located 18 representative of this dark s011 phase. The light colored phase is represented by that vast shallow basin or flat extending from Randolph County to the western part of Pike County.

In general, the Putnam silt loam near 1ts northern limit 1s darker in color than the areas further south, and grades Insensibly into the Grundy silt loam. In St. Charles County the soll has a distinot yellowlsh cast, and its greater relative fertility in this region would indicate that it is Influenced by comparatively recent loessal deposits. In all Its physical characters the type resembles the Oswego silt loam of the residual plains in the western part of the state. Owing to the level character of the surface and the more or less impervious nature of the subso11, natural drainage is deficient and artificial drainage is somewhat difficult. 
Many farmers consider that drainage is not practlcable, but the results obtained on a fer farms where tile drains have been installed indicate that it can be satisfactorily established (12) Altho the ourface is practlcally level, there is usually enough slope to give sufficlent fall, or It is usually possible to lead the drains into one of the deep gullies which have been cut back into the upland, without having to go any great distance. To insure perfect drainage, it is necessary to lay the tile lines rather close together and to exerolse care not to lay them too deep.

All of the Putnam silt loam is in oultivation. Corn, grass, wheat, and oats are the most important crops grown in the order named. A few areas of wild prairie graso remain. Clover makes a falr growth where the soll is well drained and contalns a large supply of organio matter, but most of this prafrie is not well adapted to the orop. Bluegrass ocouples the soll naturally, and all forage crops thrive exceedingly well.

The prevaling type of agrioulture is that of general farming combined with livestock raising and feeding. Commercial fertilizers are extensively used in connection with wheat and corn. The Missouri Agricultural Experiment Station(13) has found by extensive tests at various places on this so1l type that the so1l responds to all three fert1lizing elements, as well as to lime and organic matter, but that greater returns are obtained from phosphorus than from elther nitrogen or potassium. Applications of lime 
have returned a falr profit, and on much of the worn land Its use is essential if clover is to be grown. The use of barnyard manure and of green manures is also highly recommended.

Chemical composition--Putnam silt loam

$\begin{array}{lcccc}\text { Total } & \begin{array}{c}\text { Total } \\ \text { Nitrogen }\end{array} & \begin{array}{c}\text { Total } \\ \text { Phosphorus } \\ \text { Potassium }\end{array} & \begin{array}{c}\text { Lime } \\ \text { Requirement }\end{array} \\ \text { So11 } & 2771 & 894 & 28,926 & 2608 \\ \text { Subsurface } & 1430 & 827 & 25,730 & 3260 \\ \text { Subs011 } & 1187 & 1124 & 26,780 & 3134\end{array}$

Th1s data shows a rather low amount of nitrogen and phosphorus in the so11. The reaction in every case is ac1d, the subsoll being more acld than the surface s011, differing in this respect very strikingly from the Grundy silt loam.

\section{Glaclal T111 So118}

Continued study of the glacial deposits in the northern part of the State makes it increasingly evident that this material is largely derived from the ground up country rock. Th1s fact is of great signlficance, because it has influenced the character of the soll derived from the t111. In the western part of the glacial region where the limestones and shales of the upper carboniferous pervall, the t1ll is calcareous and loamy; in the eastern part of the region where the shales and sandstones occur, it $1 \mathrm{~s}$ argillaceous and comparatively shallow. The percentage of local material is 
greater also where the drift 18 thinnest. Based on these differences in origin and composition, the glactal solis have been divided Into two types--the loamy calcareous material giving rise to the Shelby loam, and the more clayey material forming the Indiey loam.

\section{Shelby Loam}

The Shelby loam is extensively developed in the northern and western part of north Missourl, and occuples practically all the rolling land of that region.

Where typically developed the Shelby loam consists of s1x to twelve inches of a friable, dark brown to yellowish brown loam, which gradually changes to a light brown, heavy loam to a depth of about fifteen inches, below which is a yellow or yellowlsh brown tenaceous sandy clay. The latter 1s mottled brown, red and gray, the color usually becoming I1ghter in the lower subsoll, especially on the more nearly level areas. The content of organic matter in the surface so11 varies considerably; on the rolling lands it is quite Ior, but on gently rolling areas, and especially at the base of slopes, the soll 18 well supplied as is indlcated by the deep black color.

The characteristic feature of the Shelby loam is the presence of sand and small gravel, thruout the 8011 mass. Both sand and gravel are rounded and water worn, and are largely of forelgn origin, consisting of quartz, granite, greenstone, gneise, diabase and many other orystalline rocks, and occasionally fragments of IImestone and chart. Th1s coarse material does not 
hinder cultivation, but tends to give the so1l a loamy structure. Occasionally the gravel is stratified as thin lenses, but as a rule it is thoroly disseminated thruout the so1l section. Such an arrangement of widely differing materials couldresult only thru the grinding and mixing of an 1 ce sheet. Lumps of lime concretions and calcareous streaks are present In considerable quantity in the subso11, and extend to great depth. Deep excavations frequently show such an abundance of calcareous material as to give the soll a chalky appearance. The greater abundance of the limy material where the drift is deepest would Indicate that the soil material was not leached before its deposition, and explains its high potential fertil1ty. The separation of the Shelby loam from the Iindley loam would be justifled on this basis alone, the greater productiveness of the glacial limestone so11 as compared with that of shale and.sandstone origin.

It is thus easy to distingulsh between the Shelby loam from the adjoining loess so1ls. The latter never contain gravel or stones, while the former is partiy made up of such material. The presence of the gravel has given good internal drainage, to which is due the yellow or reddish color, since good dralnage and aeration are favorable to oxidation. The Lindley loam being less gravelly and more clayey, is not so thoroly oxidized, and therefore is lighter colored.

The surface features of the Shelby loam are gently rolling to moderately hilly with a rather blllowy appearance. The h1lis are usually rather low and rounded, but are some- 
times sufficiently steep to offer considerable difficulty to cultivation. In general the type is more rolling in Sullivan and Putnam Counties than it 18 farther west. It is one of the most easily washed so1ls in the State, and this constitutes the most serious problem in 1ts management. This condition has influenced the type of farming, and large areas are kept in sod.

The greater part of the Shelby loam was prairie, and it was only along the streams and the more rolling areas that timber occurred. The latter conolated largely of oaks, hickory, elm, cherry, and walnut. The treeless areas were covered w1th prairle grass, hazel brush and sumac. Practically all of the type is now highly improved farming land.

As a whole, the Shelby loam is not as well supplied with nitrogen as the loess so1ls, nor does it produce quite as large ylelds of corn. It also requires greater care in handling to maintain the humus supply and to prevent injury from washing. It 18, however, a warm s011, and 18 easily handled. It 18 an excellent grass and clover s011, and under proper conditions w1ll gron alfalfa well. Blue grass is indigenous to $1 t$, and the acreage devoted to this crop exceeds the total area devoted to small grains.

The soll responds more readily to manure than do the level prairle lands. Commerclal fertilizers are not used, but the Experiment Station(14) has found that phosphat1c fertilizers on wheat, to be followed by clover, are profitable. Systematio 
orop rotations under systems of live stock farming or general farming, together with the careful using of all manure, are reconmended.

Chemlcal analys18--Shelby loam

$\begin{array}{lcccc} & \begin{array}{c}\text { Total } \\ \text { N1trogen }\end{array} & \begin{array}{c}\text { Total } \\ \text { Phosphorus }\end{array} & \begin{array}{c}\text { Total } \\ \text { Potassium }\end{array} & \begin{array}{c}\text { Lime } \\ \text { Requirement }\end{array} \\ \text { So11 } & 3005 & 1070 & 24,737 & 3645 \\ \text { Subsurface } & 2555 & 1020 & -\cdots & 6400 \\ \text { Subs011 } & 1138 & 1156 & 28,412 & 3070\end{array}$

\section{Lindley Loam}

The Indley loam includes practically all of the rolling glacial land in the northeastern part of the State. It represents also much of the timber land of this region, and thus is in striking contrast to the adjoining pralrie land.

In comparison to the other so11 types of the glacial region, the Indiey loam is the most variable, both in 1ts physlcal properties and agricultural 1mportance. The surface 8011 to an average depth of five to ten inches is dominantly a yellowlsh brown, yellowish gray, or light gray loam or silt loam. Usually there is enough sand to give the soll a gritty feel, but on many of the gentle slopes the texture is a silt loam. On the steeper slopes there is always present enough sand to give a loam or even fine sandy loam texture. The subso1l to a depth of twelve to sixteen inches is a light yellowish brown granular loam, whlch grades into a tenaceous, 
gritty, silty clay, mottled yellow and gray. The lower subso11, below thirty inches, usually is a light gray or drab, and of a silty texture. In many places, notably in Randolph, Howard, and Marion Countles, bedrock of sandstone or shale and rarely Ilmestone, 18 encountered within the three foot oection. The overlying so1I in such areas partakes of the nature of the bedrock and the only indication pointing to glacial influences 1s the occasional occurrence of a forelgn gravel in the residuary material. Sand, gravel, and chert fragments in small quantities are scattered thru the so1l and subsoll.

The Indley loam is characteristicaliy low in organic matter, due to excessive erosion and the small amount of lime In the so1l. The surface soll therefore 1s shallow, and 1s not markedly different from the subso1l. In fact, on some of the uncultivated areas and where erosion 18 severe the unproductive subsoll 11 es at the surface.

The origin of the Iindley loam and its similarity to the Shelby loam has already been pointed out. Walle the greater proportion of the material is undoubtediy true t1ll, a largo part of it consists of modified local material. Th1s is especlally true near the outer margin of the glaclal region, where the t1ll is shallowest. On the steeper slopes outcrops of the underlying rocks are much in evidence, and part of the 8011 is undoubtedly of residual origin. In some places the 8011 is apparently of glacial origin, while the subsoll is purely residual. However, scattered fragments of crystaline 
rocks are found thruout the ent1re area, even where the so11 is almost entirely of residual origin. Near its southern margin the subsoll of the Lindley loam frequently contains many chert fragments which are, of course, of local derivation. Such areas are especially numerous around Columbia. In general, the Iindley loam in the northern part of the State is more nearly derlved from true t1ll, and in these areas closely resembles the Shelby loam.

In addition to the differences already pointed out, it may be added that the Lindley loam is siltier, contalns less sand and gravel, and sand of a finer texture than the Shelby loam. Lime concretions are rarely present in the subso1l, and oxidation has not penetrated far below the surface, due to greater compaction than in the more losmy Shelby so1l. Both soll and subsoll are lacking in lime carionate, with a consequent lowex productivity.

Altho the material from whioh the Indley loam is derived 1s closely related to the underlying rocks, it has been reworked by 1ce, and this type is therefore of glacial origin. As the underlying rocks are usually not very far beneath the surface, the drift is composed largely of local material. However, the lmbedding in the drift of cryotalline rocks, which must be forelgn, shows that there has been a thoro mingling of the material by the ice.

The topography of the Indley loam varies from gently rolling, in the areas adjolning the prairies, to very rolling or 
hilly near the large atream courses. A large part of the type is too broken for profitable cultivation. Such areas are most extensive in Ada1r, Putnam, and Randolph Counties. Erosion is excessive, and this conotitutes one of the most difficult problems in the management of the type. The necessity of adding large amounts of organic matter, and of keepling the steep slopes sodded with grass is therefore apparent. A large part of the more roling land remains timbered with white and post oak, and hlckory. All of the very rolling land 1s used for permanent pasture.

In general, the Lindley loam is not as highly esteemed as the Shelby loam. The cultivated areas are used for corn and oats; In fact the acreage of the former seems disproportionately large when the topography and the quality of the soil is considered. The addition of lime, the checking of erosion,. the incorporation of organic matter and the use of fertilizer contalning a relatively high percentage of phosphorio acid, particularly on the wheat crop, are needed in the bullding up of this so11. By such treatment clover could be made to grow succesafully on most of the type, and the quality of the pasturee greatly improved. Stock farming is the type of agriculture best sulted to th1s so1l, for by this system the grass producing qualities of the soll are utilized to the most efficlent degree, and soll 108 due to erosion reduced to a minimum. 
Chemical ànalys18--Iindley loam

$\begin{array}{lcccc} & \begin{array}{c}\text { Total } \\ \text { Nitrogen }\end{array} & \begin{array}{c}\text { Total } \\ \text { Phosphorus }\end{array} & \begin{array}{c}\text { Total } \\ \text { Potassium }\end{array} & \begin{array}{c}\text { Lime } \\ \text { Requirement }\end{array} \\ \text { So11 } & 1580 & 746 & 25,030 & 1295 \\ \text { Subsurface } & 1350 & -- & -\cdots & --- \\ \text { Subs011 } & 845 & 933 & 21,960 & 2530\end{array}$

In both the Indley and Shelby so1ls the phosphorus varies in harmony with the variation in nitrogen. The supply of potassium is rather low when the texture of the soll 1s considered. The acldity is evidently very largely inorganic in character. This is indicated by the fact that the organic matter decreases whereas the acldity increases with depth.

\section{Alluvial So118}

One of the most striking features of the glacial and loessal soll province is the great extent of the alluvial or bottom lands along all the streams. This contrasts strongly with the narrow alluvial valleys of the ozark region, where the rate of erosion thru the hard rocks is extremely olow. The streams of the glaclal region have readily cut wide valleys thru the soft drift material, so that even the smallest lateral is bordered by a comparatively wide lowland plain. Associated with the wide floodplains is the comparatively fine texture of all these allupial so1ls. Th1s character is due to both the low gradient-of the streams which enables them to carry only fine material, and to the uniformly fine texture of the 
uplands from which the alluvial s01ls are derived. Exceptions that might be made to this statement occur along the Missourl and M1ssissippl Rivers, for the so1ls'along these streams represent a mixture of material from a greater variety of sources than do the so1ls along the smaller streams of more restricted drainage area.

The character of the upland so1ls is further reflected by the dark color of the alluvial so1ls. The latter contain a high per cent of organic matter, as well as soluble materlal leached out of the former. They are therefore of high average productiveness, and tend to retain this condition due to ooceslonal overflowa.

With the exception of the Missouri and Mississippl bottoms, the texture of the alluvial so1ls is rarely coarser than a loam. of the finer textures all gradations from loam to the heavlest olay are present. Of these the silt loam is the most extensive, and by far the most important agriculturally, and for this reason all the alluvial solls have been grouped under the class name of Wabash silt loam. Due allowance should therefore be made for the limitations of this classification.

\section{Wabash 811t Losm}

The surface soll of the Nabash silt losm is prevalingly a black or dark brown silt loam. In depth it is rarely less than twelve to fifteen 1nches, but may be three feet and even more. The deeper soll occurs on the loamy and silty areas, while the shallower depth prevalls on the clayey areas. The subsoll 18 rarely lighter than a silty clay, and for the most part 
consists of a rather plastic clay loam. In color it varies from black to dark drab, the lighter shades being associated with the heavier texture. In general, the lower subsoil is a drab or yellowish gray clay loam with few brown mottlings. At this depth there are frequently encountered veins or pockets of sand, especially near the stream bed.

Bordering the streams, and in most of the narrow valleys the texture 1s unformly coarser than it is back from the streams and in the wide valleys. This lo especially true along the large rivers, which are always bordered by a belt of comparatively coarse textured so11. It represents the natural levee bullt up by overflow waters and generally stands from a few inches to several feet above the general level of the bottom, with a gentle slope to the landward side. In these locations the soll may be a fine sandy loam and $1 \mathrm{~s}$ of a lighter color than the average of the type. 01d atream beds and bayous are also bordered by belts of lighter so1l simflar to that along the streams.

The heavy or clayey so1ls included in the Wabash silt loam occupy level or depressed areas within the broader bottom lands. They are extensively developed along the Grand River and 1ts large tributaries, Chariton and Platte Rivers; and in large 1solated areas along the M1ssourl and Mississippl. Land of this character is usually known as gumbo. In general it occurs as almost level tracts lying somewhat back from the lands bordering the main stream channels. In addition to being flooded practically every season, 
the soll retains an excess of molsture until far into the summer, and is consequently not well suited to agricultural purposes in its natural consition. Such soll represents the finest sediments deposited by overflow waters.

By far the greater part of the alluvial soll included In the Wabash silt loam is of a silty texture. Soll of this class Includes praotically all the bottom land along the creoks and small streams, as well as a large part along the rivers. Owing to its mode of formation it possesses a considerable depth of mellow surface Bo1l, heavily charged with organic matter, and 18 easily cultivated.

The Wabash silt loam as a whole 18 characterized by its dark color and high content of orgenic matter. In general that part of the type occurring in the region of the Marshall and Shelby solls averages darker in color and is more productive than in the northeastern part of the state. Occasional 1solated areas of poor drainage frequently contain such large quantities of organic matter as to approach a muck.

The wonderful inherent fertility of the Wabash silt loam 18 rell known. Protection from inundation and provision for adequate surface dralnage are of prime importance in the improvement of the so11. In fact, probably more than twentyfive per cent of this valuable type is as yet to be reclalmed by drainage. The cost of such reclamation $1 \mathrm{~s}$ high, but the fertility of the soll and its excellent adaptations to the produotion of all the staple crops w1Il make such investment profitable. 
Corn is the one univeraal orop for which the areas of the Wabash silt loam are especially sought out wherever it occurs. The ylelds obtained are relatively higher than for upland 80118, and frequently the crop is grown many years in succes$810 \mathrm{n}$ whout any apparent infury to the land or reduction in the yield. Wheat and oate are grown on the well drained areas with excellent results. All the grasses and meadow crops, Including clover and alfalfa, thrive remarkably well wherever drainage is properly established. Poorly drained areas produce large ylelds of coarse hay. All the lighter phases of this so1l type are well sulted to the growing of potatoes, and the possibilities along this line have not as yet been fully appreclated. It is only in the loamy alluvial lands in Ray, Carroll, and Osage Countles that potatoes are commerically grown. In brief, the Wabash silt loam represents one of the most valuable so1ls in the State.

Ohemical analygis--Wabash so1ls

Wabash S11t Loam

Total Total Total Lime Nitrogen Phosphorus Potassium Requirement

\begin{tabular}{|c|c|c|c|c|}
\hline S011 & 3989 & 1558 & 30,867 & 1442 \\
\hline Subsurface & 2460 & --- & $-\cdots$ & --- \\
\hline Subso11 & 1989 & 1382 & 31,837 & 1803 \\
\hline - & Wabash & y Clay & Clay Loam & \\
\hline S011 & 4898 & 2348 & 31,378 & 3547 \\
\hline Subsurface & 4255 & $-\cdots$ & $-\cdots$ & $\cdots$ \\
\hline Subso11 & 2496 & 1768 & 29,106 & 665 \\
\hline
\end{tabular}




\section{Residual Prairie So11s of West M1ssour1}

The residual prairie soils of west Missouri occupy a triangular shaped area, covering about seventeen counties, or an area about one-third the size of the glacial and loessal so11 province. On the north they blend imperceptibly into the so118 of the latter region; the eastern boundary is 1rregular, but is everywhere rather clearly defined by the presence of the cherty and hilly s011s of the Ozark reglon. In general, these so1lo form the eastern edge of that great pra1rie region whioh is so extensively developed in Kansas and Oklahoma. In their agricultural importance they rank second In the State.

It is interesting to note that the rocks from which the residual prairie soils are derived also form the basal structure in the northern part of the state, and it can readily be assumed that were it not for the glacial covering the soll of this region would be similar to those south of the river. Such areas of residual soll as do occur north of the river (Ray, Clay, Caldwell, LIvingston, and Carroll Counties) are the same as in the residual prairle region. Moreover, the fact that some of the glacial prairies are similar to the residual prairies 18 no doubt in a large measure due to the partial derivation of the former from the country rock. This is further emphasized by the occurrence in zones or belts of similar types, and the conformity of these zones. to the related basal rooks. Thus the gray prairie so1ls in both the glacial and residual 
region (Putnam, Oswego, Cherokee) conform in general to the distribution of the shale horizons; the black prairie solls (Summit, Grundy) overlie in zones the Iimestone-shale horizons. In this consideration it would have to be assumed that the glacial prairle solls (Putnam, Grundy) are not of aeolian origin, but that they are largely of local material, the latter assumption beling very unlikely.

The character and distribution of the residual prairie so1ls presents some very interesting considerations, and 11Iustrates in a remarkable way how s01ls are affected by the mother rock, especlally in the presence of limestone. It has already been polnted out that the rocks of this region conslst of limestone, shale, and sandstone. The former occurs in the northwestern part of the area, the latter in the southeastern part, with the shales forming an intermediate zone. Where the Iimestone occurs and has actively entered Into the composition of the soil, the black prairie or summit silt loam prevalls. Originally the limestone extended much farther east, and where 1ts residual effects remain the so1ls are dark gray in color, contaln only a medium per cent of organ10 matter, and are classed as Oswego silt loam. The so1ls derlved from the shales and sandstones, and not influenced by Ilmestone, are prevalingly light colored, and have been classed with the Cherokee and Bates series. The dark color in s0118 and the correaponding higher content of organio matter thus seems to be associated with an abundance of limestone or calcium carbonate in the so1l. Further lllustration of this con- 
dition are the 1solated mounds and ridges capped with limestone, so numerous in Bates, Vernon, and Henry Counties. The weathering of the limestone keeps the lower lying soll supplied with calcium carbonate. The soll on the slopes of these mounds would normally be of a light color and contain little organic matter due to the excessive erosion, but strangely enough they are covered with a deep dark soll--in striking contrast to the gray and less productive solls surrounding the mounds and beyond the influence of the weathering limestone. The residual pratrie so1lb, as a whole, are not as productive as the solls of the glacial province. Th1a, no doubt, is partiy due to their greater age, the consequent greater leaching they have undergone, and the stratification of the soll material. This latter character is especially pronounced in this region, and 18 even present in the sandy loams, so1ls which normally do not readily become stratifled. It 18 to be noted, however, that those so1ls with a high content of organic matter do not possess this characteristic or $1 f$ so only to a modified degree. Thus, the summit silt loam shows much less stratification than the Oswego or Cherokee types. This characteristlc seems to hold true for all solls, even those of alluvial origin, but, to our knowledge, has never before recelved recognition. It can not be attributed to a difference in age, origin, or molsture content, for all these solls were formed simultaneously under similar conditions. - Evidence indicates that it is due to a difference in content of calcium carbonate, or possibly of organic matter. 
The power of lime to flocculate soll partlcles is well known. An abundance of this material, espectally in the presence of organic matter, seems to retard the downward filtration of the clay particles and the translocation of the fron and other semi-soluble constituents of the so1l mass. Th1s whole matter of lime, organic matter, and the stratification in solls, suggests an interesting problem for future investigation. Russlan Investigators have done much along this line(15).

Topographically, the region of the western prairie sollo forms the most extensive area of almost level land in the State. Except along its eastern border, where the streams have cut down to moderate depth, the whole surface is that of a level to gently undulating plain. The streams have wide, shallow floodplains, and in many places grade almost imperceptibly into the uplands. In general, the surface features are almost 1deal, and permit of the highest type of agriculture.

\section{Summit S1lt Loam}

The summit silt loam, frequently known as 'black limestone land'', Includes the greater part of Jackson, Cass, Bates, and Johnson Counties, and portions of Vernon, Henry, Pettis, and LaFayette Counties. Detached areas of the type ocour in Clay, Caldrell, and Carroll Counties, north of the Missour1 River. It 18 prevalingly a heary silt loam with a rather heavy, plast10, s1lty clay subsoll. Typically, the surface 8011 is a black, dark brown, or very dark gray 
silt loam, ten to elghteen inches in depth, and containing a good supply of organlc matter. The subsoil is a dark drab to dark gray clay loam, changing at about tranty-four inches to a yellowlsh gray granular sllty clay, mottled yellow and gray. The gradation from soll to subsoil is gradual, and 18 not marked by a sudden change in color or texture. Usually the true subsoll is not reached at less than elghteen inches, where the soll material becomes compact and waxy and the content of organic matter quickly decreases. Lime concretions and calcareous streaks are found In the subsoll and indicate that it is fairly well supplied with lime. A peculiar characteristio of both soll and subsoil, especlally where the type occurs near limestone outcrops, is that it has a tendency to granulate or break up into cubes, with the reault that it does not puddle readily. The Summit silt loam as a whole is rather uniform, such variations as occur beling of minor importance and need to be considered only briefiy.

Poorly drained areas, usually at the head of shallow draws, are black in color in both 8011 and subsoll, and in texture are almost a clay loam. Such areas are frequently known as "gumbo'. Another variation 1s the so-called 'mulatto land'. The surface soll is a dark brown mellow silt loam, grading at about flfteen inches into yellowlsh-brown or reddish-brown crumbly silty clay loam. The subsoll averages lighter in color and texture than the corresponding layer in the sumit silt loam. The soll material 1s derived chlefly 
from limestone and shale, the former probably entering into the formation more largely than the latter. The mulatto land occurs along streams, and averages more rolling in topography and has more limestone outcrops than the typical 8011. In 1ts agricultural value it is equal to or superior to the latter, and is especially prized for alfalfa. It is extensively developed in Jackson, Cass, and Johnson Countles.

Included in the Summit silt loam are omall areas of Summit stony clay loam. The latter occupy the 1solated hillocks, the sldes of ridges and escarpments and stony slopes near streams. In these areas thin bedded limestone outcrops and fragments of the stone are scattered over the surface and make cultivation difficult. The 8011 material is dark gray to yellowlsh brown plastic clay. Most of the land of this character is in pasture and orchard to which it is well sulted. Most of the Summit soll in Clay, Ray, and Carroll Counties belongs to this phase.

Thruout 1ts ent1re extent the summit silt loam has a level to gently rolling surface admirably adapted to a heavy type of farming. The undulating swell of the surface everywhere is sufficlent to insure good drainage. The streams and draws flow thru shallow valleys, and the level of the plain 18 rarely more than twenty to fifty feet above the valley bottoms. In general, the areas north of the Missourl River average more rolling than the main body of the type south of the river. The depth of the soll mantle 1s deep, 
frequently fifty or sixty feet, and the underlying rocks are rarely exposed. Limestone has entered more largely into the composition of the soll in the northern part of the type than in the southern part. The original vegetation conslsted of prairle grass, with narrow belts of elm, oak, h1ckory, and walnut timber along the streams.

The Summit silt loam is one of the best so1ls in the State, and compares favorably with the better glaclal and loessal solls of northern M1ssour1. All of the type is highly improved, and is used for general farm crops, such as corn, wheat, grass and oats. Ylelds range as follows: corn, 30 to 75 bushels; hay, one to two tons per acr $\$$, on the better farms, the higher flgures being approached more frequently than the lower. In Cass County tobacco is grown on a commerclal scale, with ylelds of 1000 to 1600 pounds per acre. Clover and alfalfa thrive on all of the type. Commerclal fert1lizers are not used, but applications of phosphatic materials would probably prove profitable. Appli cations of ground limestone would be beneficlal on the poorer drained areas. In the management of this type, the most important consideration is the maintenance of the organic matter supply, for besides adding fertility, it tends to keep the rather heavy soll in a loamy condition.

Chemical analysis--Summit silt loam

Total Total Total IIme Nitrogen Phosphorus Potassium Requirement

So11

28,435 
In the total amount of plant food the summit silt loam compares favorably with the loessal so1ls of northern Missouri. Even the subsoll is well supplied with nitrogen. The rather high lime requirement is undoubtediy due largely to organic acids, as is indicated by the decrease of acidity with a decrease in the organic matter.

\section{Oswego S11t Loam}

The Oswego silt loam, like the Summit silt loam, forms part of the black prairle solls of western Missourl. In fact, the separation of these tro types is extremely difficult where they come in contact, and the boundarieg therefore are in some places more or less arbltrary lines. Geographloally and agriculturally the 0swego silt loam lies between the Summit s1lt loam on the north and the lighter Cherokee and Bates so1ls on the south. In 1ts physical properties it 1s characterized by a dark silty surface so11, nearly level topbgraphy, and a st1ff clayey subsoll.

Typlcally, the surface soll is a dark gray, grayish brown to black mellow silt loam, becoming somewhat lighter in color at about ten to twelve inches, or in the lower six inches of the top silty layer. This light colored subsurface is not always present, and can not be considered a characterlstic of the type, altho in general it holds true that the subsurface is lighter colored than the surface so1l. Usually the well developed, gray layer occurs only on broad, level areas, 
and is absent where the surface is rolling. The subsoll at a depth of about sixteen to elghteen Inches is a dark drab to yellowlsh gray, stiff, tenaceous clay, passing gradually at about twenty-six to thirty inches into a more friable silty clay, mottled gray and yellow. The layer of heavy clay outcrops in banks and cuts as a brown granular clay. Where the heary subsoll is hard and compact as on the flat poorly drained areas, it is locally known as "hardpan". In very wet or dry seasons these areas give considerable trouble to the farmer. They are most common in Bates and iuorgan Count1es. This hardpan seems to be due to a compact structure of the clay rather than to lime or iron cementation.

The Oswego silt loam occurs as an 1rregular belt extendIng from Moniteau County to the Kansas State IIne, and Includes parts of Cooper, Pettis, Johnson, Henry, Bates, and Vernon Counties. In the latter two counties it forms the level basin-like areas within the summit silt loam, but to the east it occupies the broad interstream divides. The characterist1c topography, which is level to undulating, is due largely to the uniform weathering of the shales from which the oo11 1 s derived, and the underlying horizontal bedo of IImestone upon which the type rests. In general, the surface drainage 1s well established, but subdrainage is deficient.

The Oswego oilt loam is a general farming so11, and in Its productivity compares favorably with the Summit ollt loam, 
altho the average yields are somewhat lower than on the latter. Corn is the chlef and probably the most profitable crop. Wheat and oats are extensively grown, with average yielis of 15 and 35 bushels respectively. Clover is grown to a limited extent. In recent years compeas and soja beans have come 1nto wlde use. In general, a larger per cent of the Oswego s1lt loam 18 used for grass and small grains than of the Summit silt loam, and this fact would indicate the relative adaptabllity of the two types.

Commercial fertilizer is used on much of the type on wheat land with good results. The soll uniformly shows a high lime requirement, and heavy applications of ground Iime-. stone are recommended.

Chemlcal analya1a--Oswego silt loam

Total Total Total Iime Nitrogen Phosphorus Potassium Requirement

$\begin{array}{lllrr}\text { So11 } & 3166 & 1583 & 27,500 & 6000 \\ \text { Subsurface } & 2466 & 1700 & -\ldots & 6250 \\ \text { Subso11 } & 1949 & 1751 & 23,840 & .1211\end{array}$

\section{Cherokee S1lt Loam}

The Cherokee silt loam is locally known as 'white ashy land" owing to 1ts light color and ashy texture, or"hardpan land"because of its tough, impervious subso1l. It is closeIy related to the Oswego silt loam, but has undergone more weathering and leaching, with a resultant loss in plant food 
and change in so11 structure. The soll particles have disintegrated 80 as to be of a clayey texture, and have been washed down and accumulated in the subsoll, giving the latter a close and compact structure. The numerous iron concretions indicate poor drainage and the lack of mineral plant food. These conditions, no doubt, are the result of the absence of calclum carbonate in the so1I, for without this element flocculation of the so1 particies and accumulation of organic matter is retarded.

The surface soll of the Cherokee silt loam is a gray or bromish gray silt loam to a depth of about ten 1nches, and Is underlain by a light ashy gray, floury silt loam somewhat more compact than the surface portion, and frequently mottled with rusty brown ferruginous material. The subsoil, beginning abruptly at sixteen to eighteen inches, consists of a brown, dark drab or nearly black, stiff, tough; waxy clay, changing in the lower section to a light drab, friable silty clay, mottled yellow and gray. Where the type occurs near streams, the surface soll contains some fine sand, and the subso1l averages gray or light drab in color, and is highly mottled red and yellow.

The ashy gray subsurface and the brown, stiff clay subso11 are the distingulshing characteristics of the type. The subso1l when wet 18 gummy, but when dry 18 hard and 1 tractable. Water passes thru it slowly. Iron concretions are numerous thruout the so1l section. Fine argillaceous shale is the origin of the soil material. 
The topography is level, and averages smoother than any other upland type in the state. Any change in elevation from that of the given area of the type means the passing into a different s011, usually the Bates fine sandy loam. The type 1s frequently surrounded by solls of a more rolling topograghy, thus giving it a basin-like appearance; other areas occur along streams, and resemble hlgh flat terraces.

The surface dralnage is poor and the underdrainage incomplete. The level surface, lack of organic matter, and the almost impervious subsoll combine to produce unfavorable molsture conditions, and can only be improved by open ditches and t1le drains. The soll is not drought resistant and frequent shallow cultivation is of special importance during dry per1ods.

A large proportion of the type, particularly in Vernon and Barton Counties, remains as virgin prairle sod, and produoes one to two tons of hay per acre. The oultivated areas are used for corn, wheat, cowpeas, and kafir. Yields of the former range from 20 to 35 bushels, but in unfarorable seasons frequently average less than ten bushels per acre. The type is best sulted to grass and small grains, and in recent years the acreage of the latter has been increasing due to fertilization. Commercial fertilizers are extensiveIy used on corn and wheat with good results. 
Chemical analysis--Cherokee silt loam

$\begin{array}{lcccc} & \begin{array}{c}\text { Total } \\ \text { Nitrogen }\end{array} & \begin{array}{c}\text { Total } \\ \text { Phosphorus }\end{array} & \begin{array}{c}\text { Total } \\ \text { Potassium }\end{array} & \begin{array}{c}\text { Ilme } \\ \text { Requirement }\end{array} \\ \text { So11 } & 2580 & 712 & 20,320 & 2948 \\ \text { Subsurface } & 1680 & 927 & 22,300 & 3126 \\ \text { Subso11 } & 1688 & 880 & 18,720 & 4652\end{array}$

The soll is markedly deficient in phosphorus, potash, and organic matter, and the need of stable manure, legume manure crops, and phosphatio fertilizers is apparent. Numerous tests show the soll and especlally the subsoll to be acld, and heavy applications of ground limestone are recommended (16).

\section{Bates Fine Sandy Loam}

The Bates fine sandy loam has a wide distribution in the southwestern part of the State, and is one of the most var1able types mapped. The prevaling texture is that of a coarse loam, but ranges from sllt loam to coarse sandy loam. The subso1ls are somewhat heavier than the surface s011s, but a friable structure is maintained in every condition. The surface s0118 range in oolor from brown, dark brown to yellowlBh gray, the darker shades predominating on the smoother areas, especially in the northern areas of the type. The subsolls are some shade of brown and show bright mottings of red, brown, and yellow. Sandatone fragments are scattered thru the so11,- and frequently bed rock is encountered on the 
steeper slopes.

The silty areas included in the Bates fine sandy loam consist of a dark brown to grayish brown silt loam, grading at about e1ght to twelve inches into l1ght brown friable silt loam, which $1 \mathrm{~s}$ underiain at about elghteen to twenty inches by crumbly silty clay or fine sandy clay, highly mottled red, brown, and yellow, Th1s silty phase occuples the almast level areas of the type and is typlcal prairie land. The Bates loam and Bates fine sandy loam have brown or graylsh brown surface s011s, with yellowlsh brown subso1ls of a somewhat heavier texture than the surface material. In general, any increase in the unevenness of the surface is accompanied by an Increase in the coarseness of the soll material, and this in turn is accompanied by an increase in the motting of the subso1l. Associated with the more roling areas is a larger amount of shale and sandstone fragments disseminated thru the so11 and subso11. Sandstone outcrops are common, and steep slopes of stony loam are found.

The most persistent characteristio of the Bates so11s is the bright red mottilngs of the subsoll, frequently so in tense as to give the lower subsoll a red color. Th1s condition. Oxidation of the s01I material to a great depth. The soll contains a relatively high per cent of 1ron, but due to its complete weathering it is granular, and rarely Imparts any objectionable character to the so1l. Unlike most upland s0118, the Bates fine sandy loam becomes coarser downward, especially when the underlying sandrook is not more 
than three to four feet below the surface. The so1 material is derlved from sandstone and shale. The former is only a few feet in thickness, so that the resultant soli is varled and rather silty where the shales predominate.

l'he Bates fine sandy loam forms an irxegular belt along the southern and eastern edge of the residual prairle region. It occurs most extensively in Barton, Vernon, Cedar, St. Cla1r, and Henry Countles, altho numerous small areas are found in adjolning counties. The general location of the type is indicated on the so11 map. However, it must not be considered as occuplying all the country indicated as this type on the map. In many places (of level surface) are included small patches of Cherokee silt loam, which are usually only a few acres in extent and therefore too small to be indicated. Near the eastern edge of the type there are included areas of stony loam that probably belong to the Ozark solls.

The surface features of the Bates fine sandy loam vary from level to steeply rolling. The former represents the typical prafrie land, while the latter includes the mounds or hlllocks, and timbered land bordering the streams. Prao tically all of the type can be easily cultivated.

Corn, grass, and cowpeas are the most important crops grown. A large part of the type remeins as virgin prairle sod. Corn is extensively grown, and where the soll is well supplied with organ1c matter falr ylelds are obtained. Wheat is not extensively grown except on the silty areas, and re- 
quires fertilization to produce profitable crops. Cowpeas and kafir thrive remarkably well. The lighter textured soll 1s highly prized for small frults and truck. Alfalfa has been trled with some success, but, owing to the deficiency in both so11 and subsoll of lime carbonate, this type is not particularly adapted to this crop.

While the Bates fine sandy loam is not naturally considered a strong s011, and whlle it quickly deterlorates under bad management, it can, by the use of proper rotations and treatment, be brought up to a rather high state of productiveness. Chemical analysis shows it to be low in all three fertilizing elements, as well as in lime and organic matter. The presence of the latter 18 especlally important, as it is only when the so1I is well supplied with this material that It w11l lose 1t droughty tendency and be less subject to erosion.

Chemical composition--Bates s011s

Bates Silt Loam

Total Total Total Lime Nitrogen Phosphorus Potassium Requirement

\begin{tabular}{|c|c|c|c|c|}
\hline So11 & 3187 & 1436 & 21,873 & 5673 \\
\hline Subsurface & 2733 & 1653 & $\ldots-\cdots$ & 7666 \\
\hline \multirow[t]{2}{*}{ Subso11 } & 1660 & 1083 & 18,807 & 386 \\
\hline & \multicolumn{4}{|c|}{ Bates S0118--Coarser than Silt } \\
\hline So11 & 2336 & 763 & 14,904 & 3 \\
\hline Subsurface & 2740 & -- & $-\cdots--$ & \\
\hline Subso11 & 1310 & 650 & 17,060 & \\
\hline
\end{tabular}




\section{Osage S1It Ioam}

The Osage silt loam represents the alluvial so1ls within the residual prairle region. The type has a wide range in texture, but the class name has been used to indicate the predominating character. Aside from the difference in origIn, the Osage s0118 are lighter in color than the Wabash so1ls of the glacial region, but are darker than the Huntington s011s of the Ozark region. In general, the Osage so1ls vary from black to light gray in color, altho dominantly they are dark brown or dark gray. Texturaliy they range from fine sandy loam to heavy clay, with a preponderance of the finer grades.

l'he Osage silt loam 18 by far the most extensive type, and completely occuples the valley bottoms along all the larger streams except where interrupted by the Osage clay. It conslists of a black, dark gray, or gray, mellow silt loam w1th a drab or gray silty clay subso11. Frequently there is little change in color or texture thruout the soll section, but in general the subsoll contains more clay and is lighter in color than the surface so11. That portion of the type In the region of the Summit and Oswego so1ls is much darker in color and the surface so1l deeper than in the southern areas. In the region of the Cherokee and Bates solls-notably in Vernon, Barton, and Henry Counties, the surface so11 1s prevalingly a light ashy colored material carrying many Iron concretions, underlain at about twenty-four inches by a gray clay. Th1s light colored phase is poorly drained and 
1s not productive. The greater part of it 1 s timbered with w1llow, oak, ash, elm, and hickory.

The Oaage silt loam, particularly the dark colored phase, 1s easily cultivated and highly productive. The greater par $t$ of It is used for corn, and ylelds of 35 to 75 bushels are obtained. Areas not subject to overflow and that have good Internal dralnage are well sulted to alfalfa. The greatest need of the soll is good dralnage and liberal quantities of organle matter.

. In the region of the Bates fine sandy loam the alluvial soll is usually of a loam texture. The surface soll to a depth of ten to fifteen Inches is a dark brown or grayloh brown loam or fine sandy loam, with a yellowish brown subsoll. The most extensive areas of this phase occur along Horse and Clear creeks in Bartion and Vernon Countles. It is highly prized as a corn, clover, alfalfa and truck soll.

The areas of heavy clay soll within the Osage silt loam are locally known as 'gumbo''. It consists of a black, heavy, silty clay elight to twelve inches in depth, and underla1n by bluloh black or drab heavy, waxy, tenaceous clay. The latter, when dry, cracks and becomes hard and intractable. The surface so11, altho it contains a large amount of organto matter, is difficult to work except under the most favorable conditions as regards molsture.

The most extensive areas of Osage clay are found along the Osage River and 1ts large tributarles in Bates, Cass, Henry, and Vernon Counties. All of the type is subject to 
prolonged overflows, and therefore little of it is under cultivation. It produces coarse hay, averaging one to four tons per acre. When molsture conditions are favorable corn and grass do well. Tile draining, liming, fall plowing, and turning under coarse organlo matter are some of the factors essential to improve the efficlency of the so11.

Chemical analyo1s--Osage silt loam

Total Total Total Lime Nitrogen Phosphorus Potassium Requirement

So11 2976

1312

26,160

1220

Subsurface

2100

1750

1500

Subso11

1474

1343

28,986

2800

In composition this soll is falrly well supplied with all the essential plant food elements, if we consider the very deep leeding range afforded to plant roots. 
Solls of the Ozark Region

\section{General Description}

The solis of the Ozark region as a whole possess characteristics that distinguish them from all others in the State. In general, they are light in color, comparatively low in organic matter, and are more or less stony in character. That they are for the most part timbered, hilly in topography, and that they are rather low in mineral plant food may be given as other characteristics which, however, apply only in part to the region. The prevallIng colors are gray, brown, and red with an almost total absence of black. The subsolls are gray, yellow, and red, the brighter colors being associated with correspndIng shades in the surface s011. The content of chert gravel in the soll varles greatly; in some places it covers the entire surface while in others it is almost entirely absent. In general, the more level areas are the least stony. True clays do not occur in the entire Ozark region. The fine materlal of the surface soll is almost universally silty, and the subsoll is rarely heavier than a silty clay. It is true that the latter frequently is compact and more or less impervious, but this is due to the small amount of organle matter and to more or less cementation of iron material, and not to the thick accumulation of clay.

On the basis of color and content of chert gravel the Ozark so1ls form two general groups: those of a red or brown color and moderately cherty, and those of a gray color and 
very cherty. The former surround the latter and are frequentIy known as the Ozark border solls. They are derived from moderately cherty limestones belonging mostly to the lower carbonfferous group. The gray solls are from very siliceous Iimestones of the Cambro-Ordoviclan system. They have a more broken surface and are of lower agricultural value than the red solls.

Since all the Important soll forming rocks of the ozark region are limestones, it has required many feet of rock of the purer beds to form even a thin layer of soll. In the small amount of residue there is a relatively great concentration of 1ron, the concentration being greatest where the parent rock was purest. The oxidation of the iron gave to the soll particles the characteristic red or brown coloration. Where the cherty limestone solls occur a gray coloration prevalls. Since much of the Iron oxide has been washed from the surface soll into the subsoll the latter is always of a brighter shade than the former. It is of interest to note that iron concretions rarely occur in limestone s011s, and If found are present only in such solis as are thoroly leached to considerable depth.

The Ozark solls are the oldest in the State and have therefore become thoroly leached. Moreover, the hardness of the rocks from which they are derived has required a long time for weathering. Not enough lime is left to make the surface soll truly alkaline, and organic matter has not accumulated in sufficient amount and in proper form to give 
It a dark color. Even the areas overlying the pure carbonate stones usually show an acld reaction, and only the lower subsoll overiying the parent rock shows effervescence with ac1d. The Crawford gravelly loam beling the youngest of the Ozark so1ls and coming from a rather pure limestone frequently shows alkaline properties, and contains a relatively high per cent of organic matter. The effect of age has been greatly intensifled by the open, porous nature of the 8011s. This is indicated by the pale gray color of the so11 material of the gravelly members of the group. In general, the greater the content of gravel the lighter the color of the so1l. The prevailingly low content of phosphorus would indicate that this element has been removed together with the calcium and other minerals. The effects of weathering extend to a depth of forty or more feet, as ls indioated by the discolored material found at such depths when digging wells.

Thru the erosive action of water the Ozark solls are continually losing their finer silt and clay-like particles almost as fast as they are formed, on account of the hilly surface. The tendency of the soll material to occur as zones or layers 18 therefore retarded. Glinka(15) states that so1ls derlved from rocks rich in calclum carbonate do not podzolize. readily. It $1 \mathrm{~s}$ probable that both the action of erosion and the character of the parent rock do not permit the translocation of the soll particles so as to form layers. The remo- 
al of the clay and the leaching away of the soluble material tends to make the soll of all formations alike. The matter of the geological age of the rocks and to a large extent the character of the rocka is therefore of only general interest. It 1s probable that in the so1ls from the purer limestones leaching and clay filtration have been retarded to a greater degree and therefore they are heavier in texture and contain a larger per cent of plant food. 


\section{Solls from Chert Free Limestone}

\section{Hagerstown Silt Loain}

The Hagerstown silt loam is the red limestone land of the eastern Ozark border region. It occurs in belts with a general north and south trend conforming to the outcrop of the limestone horlzons from which the soll is derived. The eastern belt extends from southern Cape Girardeau County to Jefferson County; the western belt occurs in Mad1son and St. Francols Counties. North of the Missouri River the type occurs in Pike, Iincoln, and adjoining count1es. The total area is probably little more than eight hundred square miles.

Ihruout the region of its occurrence the Hagerstown silt loam is characterized by a brown or a yellowlsh-brown silty loam surface soll which varies in depth from eight to fourteen 1nches. It is mellow, stone-free, and contains a fair supply of organic matter. The subsoll is a brown, reddish brown, or yellowlsh brown ollty clay which grades into a heavier clay loan at a depth averaging thirty inches. On the relatively smooth areas, especially in St. Francois County, the immediate surface so11 is a light gray, and the lower subsoll is mottled brown and yellow and is of a very friable structure. Near Iimestone outcrops the soli has a bright reddioh brown color, grading into a dark brown or almost black in areas where organic matter is abundant. 
The soll mantie giving rise to the Hagerstown silt loam is of great thickness, and it is only on a few of the steep slopes and in the bluffs bordering the larger strears that the bedrock comes to the surface, or that Iimestone fragments are scattered thru the so11. In general; the area in BolIinger County is more stony than the typical, and includes some stony loam.

The topography is prevailingly undulating to rolling, except along the creeks where it is hilly. The Pike and Bollinger County areas average more roling than the remainder of the type. Sink holes are of frequent occurrence in Cape Girardeau and Perry Counties.

The Hagerstown silt loam is derived from limestones belonging to a wlde range of geological ages, from the lower part of the Ordovician to the Mississipplan, all alike, however, in being rather pure chert-free limestones. The solis therefore are stone-free. In St. Francols County some of the Iimestone is dolomitic and is more argillacecus; passing in a few localities into shales. Such places are usually assoclated with a clay soil that has a gray or yellowish color. In general, it seems to hold true that where a magnesian Iimestone gives rise to this type the surface so1l is I1ghter In color than the typical, and the subsoll more of a reddiah brown. The content of organic matter seems to be lower, blue grass grows less vigorously, and the soll appears less 
productive than where the calcium Iimestone prevails. In Pike County nore or less glacial material has been mixed with the IImestone so1I.

The Hagerstown silt Ican is easily distingulshed from the other so1l types occurring within the same region (1.e. ozark region) on account of its brown color, smoother topography, and freedom from stones. However, it is in many respects closely related to the Crawford graveliy loam. In fact, were it not for the gravel in the latter these two typer could be correlated as one.

l'he liagerstown soll is old, being derived from some of the oldest rocks in the state. Wuch of the clay has therefore been washed out of the surface soll and filtered into the subso11, and practicaliy all of the calcium carbonate has been removed. The eubsoll rarely shows effervescence when treated with acid, differing thus from the Crawford subsoil which usually effervesces freely. Assoclated wth a lower Iime cortent is a lower humus content, in spite of the fact that the heavier soll is favorable to formation of a large amount of this material. It is more than probable that the difference in Iime content accounts for the greater produotivity of the Crawford so11. The need of lime on much of this so11 is indicated by the better stand of clover when lime is applied to the land. The uniformity of the soll in the different areas Indicates further that it is not so much the age or even the physical differences in the rocks, but rather the differences 
in weathering that determines the character of the soil. The Hagerstown silt loam was one of the first so1ls in Missouri to be farmed, and much of the type has been in continuous cultivation for more than one hundred years. The superior productiveness of the red soll above all others in the eastern Ozark region was early recognized. As a result very little land of this character remains uncleared and untilled, and practically every avallable acre in all locallties where this soll type is found is used to maintain a high-class agriculture. Wheat is by far the most important crop. Corn, clover, cats and grass are also extensively grown. Land that has been well treated, manured and carefully cultivated w1ll produce 20 to 35 bushels of wheat, 40 to 65 bushels of corn, and one to two tons of clover hay per acre. In the St. Francols County area the yleids are considerably lower than this, partiy on account of the poorer quality of the land, but largely because of the inferior farmpractices prevaling there. The continued growing of grain has greatly reduced the amount of organic matter in the so11, with a consequent reduction in crop yields. In order to malntaln the higher ylelds the use of commercial fertillzers on all small grain has become general. The need of making and using more menure and the necessity of growing green manure crops is apparent, for by such practices the soll can be restored to a much higher productiveness. Alfalfa can be grown with proper management, but it is for clover that this so1I is 
especlally well sulted.

On the whole, the Hagerstown silt loam offers splendid opportunities for profitable improvement, for the potential productiveness of much of this type has not as yet been fully acpreciated.

Chemical analysis-Hagerstown silt loam

$\begin{array}{cccc}\begin{array}{c}\text { Total } \\ \text { Nitrogen }\end{array} & \begin{array}{c}\text { Total } \\ \text { Phosphorus }\end{array} & \begin{array}{c}\text { Total } \\ \text { Potassium }\end{array} & \begin{array}{c}\text { Iime } \\ \text { Requirement }\end{array} \\ 1340 & 1035 & 31,600 & 1320 \\ 765 & 1225 & 33,635 & 1765\end{array}$

These flgures show a rather low content of nitrogenless than half as much as in the Crawford soll--but a rather high per cent of potassium. Fertilizer applications show good returns from phosphates, while potash gives slightly increased yields, but it is probable that the liberal use of organic matter would tend to make avallable the 3011 potash In sufficlent amounts for normal crop needs.

So1ls from Moderately Cherty Limestone Union Silt Loam

The Union silt loam includes the greater part of the northern and northeastern border of the ozark region. It begino in Bollinger County and runo northward as a belt of varyIng width to Franklin County, where it turns westward and finally ends in the eastern part of Cooper County. A considerable 
part of the northern belt lies north of the Missouri River, and includes the southern parts of Callaway, Montgomery, and Farren Counties: The details of the distribution of this so11 type are shown on the so11 map.

In 1ts prevaling characteristics the Union silt loam is a brown, grayish brown, or yellowloh brown, mellow, stonefree silt loam, with yellowloh brown ollty clay subsoil. The depth of the surface scil.and the content of organic matter vary considerably, but are in both cases greatest on the smoother land and in the northern part of the type. The subsoll is rarely heavier than a silty clay, and is usually distinctly friable. Probably the most persistent and distinctive characteristic is the faint gray and brown mottling of the lower subsoll. Occasionally this strata shows a slight cementation of iron material, but in no case can it be considered as of a "hardpan" nature. The substratum sometimes consists of a mass of chert, and chert fragments scattered thru the soll. The cherty areas occur in patches and represent knolls and steep hillsides. They are most numerous in the southern part of the type where it borders the Clarksville so1 Is. Here, too, are found outcrops of bedrock, and the subsoll is of a reddioh coloration. In Frankin County much of the so1l contains varyIng proportions of sand, usually small except on the higher land close to the outcrop of sandstone. In general, the 8011 mantle giving rise to the Union silt loam is of great 
thickness and in this respect is similar to the other red Iimestone so11s of the Ozark border.

'hat portion of the Union silt loam west of Gasconade County, and extending across Osage, Cole, and Moniteau Count1es averages Ilghter in color and contains more clay and chert outcrops than the eastern part of the type. The surface so1l is gray to yellowlsh brown silt to clayey silt, underlain by gray1sh, yellowish brown silty clay or clay subsoll. The country rock, a thin bedded argillaceous to finely crystalline magnesian Ilmestone with a small amount of chert, outcrops rather frequently on steep slopes but very rarely in the fields. The soll layer is occasionally thin, but Iimestone 'glades'" do not occur typically. Due to erom sion and weathering the surface so11.near the top of the h1118 18 shallow and contalns little organic matter. The lower slopes therefore constitute the tilled land, while the higher ground is largely used for pasture. Much of it remains timbered.

'he topography varies from rolling to hilly, with practlcally no smooth land. As a rule the hills are rounded with long slopes, but bordering all the large streams is a belt of rough country much of which 1 s too steep for cultivation. Along the Meramec and RIg Rivers the surface is thoroly cut to pleces, and the same is true of all the area north of the Missourl River. In Warren and Montgomery Counties an almost mountainous topography prevalis, variations 
In altitude of 500 feet are common, and probably fifty per cent of the land is too steep for cultivation. A similar area of strong relief occurs along the Osage and Gasconade Rivers where these streams cross this belt of soll. Probably thirty per cent of the land is made unfit for cultivation by the rough surface, but practically all of this is fairly well suited to pasture purposes. Erosion.18, of course, a serious problem, tho not to such an extent as 18 common on the rolling glacial so11s. This, no doubt, is due to the porous subsoll which permits the rapid absoption of water and thus reduces the amount of run-off.

The orlgin of the Union silt loam is not perfectly understood. That portion of the type bordering the Missouri River is essentialiy the same as the Knox silt loam, and is undoubtedly of loessal origin, in part or wholly. The greater depth of the soll mantle and the almost complete concealment of all rock outcrops and the 'rounded' topography are very suggestive of loess instead of residual material. To the south or away from the Missourl River the solI is undoubtedly residual, and. Is derived largely from the Jefferson City IImestones, a series of moderately cherty argiliaceous and more or less shaly and thin bedded magnesian IImestones.

The native tree growth consists almost entirely of white, red, black, and post oak, with walnut, elm, and other soft wood trees occurring on the browner lands and in the valleys. On all the steoper slopes where bed rock lles near the ourface cedar is the characteristic growth and frequently occuples the 
land exclusiveiy.

'Ihe Missouri River belt--south of the river--is practically all in cultivation, and is settled almost exclusiveIy by Germans. Of the remainder of the type, probably less than one-half is cleared. Thruout the extent of the type, wheat 18 by far the most important cultivated crop. The soll not only seems especially well adapted to this crop, but the type of people farming it favor the growing of small grains. Corn is not extensively grown on account of the erosion that frequent cultivation encourages. Red clover makes an excellent growth and is profitable both as a forage and as a seed orop. Blue grass thrives fairly well, but does not form as good a sod as on the other red limestone solls of the Ozark reglon. In fact, good blue grass pastures are rare. It 18 probable that the grass does not thrive as well on magnesian I1mestone s011s as on those derived from calcium limestone. In all the Union soll area north of the Missouri River the hilltops are capped with Burlington limestone and the soll largely derived from this formation. It was observed that in all these places the blue grass made a luxurlant growth, but farther down the slope where the magnesian limestone occurs only a sparse growth was noted. In fact, it is not incorrect to say that thruout the Ozark region where the magnesian limestones prevall blue grass does-not 'take'" the land or make a profitable crop. Apples, small frults, and vegetables all do well, tho grown 
at present only for home use. In Gasconade and Osage Counties grape growing is of considerable importance.

in general, the Union silt loam is best sulted to a type of farming that is largely dependent on dairying and live stock raising. The soli is not strong enough and washes too easily to permit frequent cultivation. However, it grows clover and other leguminous forage crops successfully, and can therefore be easily Improved and made to produce a large amount of feed. Most of the type is favorably located wth respect to raflroads and to the St. Louls market. The possibllities of the soll are many, and have been only partially reallzed.

Chemical analyo18--Union silt loam

$\begin{array}{lcccc} & \begin{array}{c}\text { Total } \\ \text { Nitrogen }\end{array} & \begin{array}{c}\text { Total } \\ \text { Phosphorus }\end{array} & \begin{array}{c}\text { Total } \\ \text { Potass1um }\end{array} & \begin{array}{c}\text { Lime } \\ \text { Requirement }\end{array} \\ \text { So11 } & 1353 & 750 & 34,583 & 1457 \\ \text { Subso11 } & 1606 & 703 & 36,666 & 460\end{array}$

Crawford Gravelly Loam

The Crawford gravelly loam nearly everywhere in the region of 1ts occurrence is known as 'red land' or 'Ired limestone land'', on account of the characteristic red or brown1sh color. The main area of the type occurs on the western Ozark border, and extends from Chriatian County northward thru Greene, Lawrence, Dade, and Cedar Counties. Smaller areas were mapped in Cass, Jackson, Pett1s, and Cooper Counties and 
in Cape Girardeau County. The total area is approximately one thousand square miles. Altho the soll has been called a gravelly loam there are included large bodies of land that are a silt loam in texture as will be subsequently pointed out.

In its typical development the Crawford gravelly loam consist of a brown, redalsh brown, or graylsh brown mellow silt loam, grading at about eight to fifteen inches into a reddish brown friable slity clay loam which becomes redder and more gravelly with depth, passing

below Into red crumbly clay generally carrying an impenetrable mass of angular chert fragments. The latter are distributed thruout the soll section, but are much more abundant in the Iower strata. The soll contains approximately ten to thirty per cent, and the subsoil twenty to seventy per cent of this material. In general, the more rolling the surface, the higher is the content of gravel. On many of the ridges and steeper slopes plowing is difficult. In the northwestern part of Greene County and the region to the north the so1 mantle is thin and bedrock is usually encountered within a few feet of the surface, and limestone fragments are scattered thru the soll. Such areas are not very drought resistant, and are therefore used largely for pasture land. In general, the southern border of the type in Christian County is more gravelly than the northern areas. On many of the ridge tops along the western 
edge of the type the soll is a sandy loarn or gray silt loam that 18 essentially the same as the Bates soll of the residual prairle region. They are derived from coal-measure shales and sandstones which have escaped complete erosion.

Near Springfield, in fact thruout the central part of Greene County, the soll is a silt loam, even the subsoll being stone-free. This area represents one of the most desirable farming sections in the State. The undulating surface, and the depth and mellowness of the soll make $1 t$ adapted to a wide range of crops, but especially well sulted for such deep rooting plants as alfalfa, clover, and also fruit trees.

The areas mapped as Crawford gravelly loam in Cass, Jackson, Pett1s, and Cooper Counties are more correctly s1lt loam in texture. The surface so1l is a dark brown mellow silt loam, grading downward into a reddish brown friable silty clay loarn. Chert gravel is absent, except on some of the steep slopes, and here bedrock is usually encountered within the three foot section. In Jackson County, especially, rock outcrops occur along most of the drainage ways, which tends to give the surface a rugged appearance. In Pettis and Cooper Counties the surface soll has a yellowish brown color, and is olightly heavier than in the areas to the west. In general, the topography of the Crawford gravelly loam 1s smooth to gently rolling. There are belts of moderately hilly country along both sides of the main streams, but when not too stony are rarely too steep for cultivation. In fact, the surface features of this soll type are not as 
broken as of the glacial lands in the northern part of the State.

It 1 s the typical soll of the coarsely crystalline, pure, moderately cherty, massive bedded, fossiliferous Burlington limestone. Altho much of the so11 in southwestern Missourl is derived from this same formation it is only where the latter 1 s moderately cherty and thickly bedded that it gives rise to the Crawford solls. Where the rock is more cherty the so1ls contain more chert and have therefore been thoroly leached and are of a lighter color. The two characteristics of a fair amount of chert and a relatively larger amount of fine material prevented excessive leaching, yet permitted thoro oxidation to a great depth. The relatively small amount of soll material from the pure limestone caused a greater concentration of the iron material, and the oxidation of this gives to the soll particles the characteristic red coloration.

Orlginally much of the Crawford gravelly loam, particularly all the slity areas, were prairle. This condition,: in the presence of an abundance of molsture and lime, caused a considerable accumulation of organic matter in the so11, and imparted to it a dark color. It 1 s thus probable that the native vegetation 1 s largely responsible for the difference between the Crawford and Hagerstown solls since both are derived from similar material and existed under simllar climatio conditions. The small area of Crawford so1I in Cape Girardeau County, derived from Burlington lime- 
stone, is a timber so1l, and 1s lighter in color than the main areas in the western part of the state.

Practically all of the Crawford gravelly loam is under cultivation and is probably the most productive of all the Ozark so1ls. It $1 \mathrm{~s}$ an excellent grain and clover so1l, a large part of it being sown to wheat every year. Yields of the latter range from 10 to 25 bushels per acre. Where the soll is falrly well supplied with organic matter alfalfa does remarkably well. Next to the loess in the northern part of the State, the Crawford gravelly loam is the best fruit so1l 1s Missouri. Apples, peaches, and all kinds of bush fruits make a strong growth and produce fruit of good flavor and coloration. General farming, supplemented by stock ralsing, dairying, and fruit growing, is the prevaling type of agriculture. Phosphatic fertilizer is extensively used in connection with wheat growing. No so1l responds more readily to applications of manure than does this red limestone soll. The many substantial farmhouses, thrifty orchards, and well tilled flelds indicate a general condition of prosperity thruout this type.

Chemical analysis--Crawford silt loam

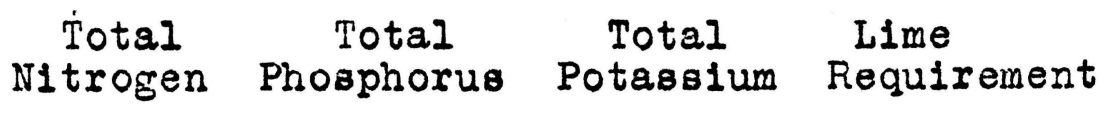

$\begin{array}{lllcc}\text { So11 - } & 2748 & 1404 & 29,510 & 3222 \\ \text { Subsurface } & 3400 & 1400 & -100 \\ \text { Subs011 } & 1720 & 1340 & 26925 & 4055\end{array}$

Crawford atony loam

So11

Subso11
2173

620
746

920
$2 ?, 926$

31,560
0

0 


\section{Lebanon Silt Loam}

The Lebanon silt loam represents the relatively smooth, stone-free plateau or ridge top soll of the Ozark region. The most extensive areas occur along the Ozark Divide, with subordinate belts of greater or less width and length running northward and southward between the watersheds of the main streams. The largest areas are found in Laclede, Texas, and Webster Counties, but much of the smooth land in eastern Ripley Courty and the extensive pratrie lands in Lawrence, Jasper, Newton, and Polk Counties also has been included in this type.

In 1 ts general characteristics the soll is a gray silt loam low in organic matter, and underlain by yellowish gray rather heavy silty clay subsoll. Typically, the surface soll to a depth of $81 x$ to eight inches is a gray to grayish brown silt loam grading into a pale yellow silt loam, which in turn changes to yellow or gray, hard, friable silty clay or clay loam. The lower subsoli is invariably a crunbly silty clay mottled gray, brown, and drab, and usually contains some chert fragments. The lower substratum consists of the stony or gravelly clay of the typical Ozark region, a residual product of the decay of the cherty limestones. Level areas with poor drainage have a light gray surface soll and a drab, heavy plastic clay subsoll. As soon as the topography becomes more rolling the subsoll is more friable, and of a brown or yellow1sh color. 
That portion of the Lebanon silt loam occurring in Lawrence, Nevton, Jasper, and parts of Polk County is similar in many respects to the Cherokee silt loam in Barton and Vernon Count1es. The surface so11 is dark gray or brownish gray, and the subsoll a drab to brownish very heavy plastic clay loam or silty clay. The lower stratum shows the usual friable structure and bright mottings, but rarely contains chert gravel. It is a rather cold soil, difficult to handle, and not very productive. The areas of Lebanon silt loam in the eastern part of the State, notably in Ripley and Carter Counties, are locally known as 'Flatwoods'. It differs from the typical soll in that it has a more redalsh or yellowish brown color and more friable structure in the subso11. At a depth of thirty to forty inches chert gravel is frequently encountered, as well as a cementation of clay and iron which forms an almost impenetrable mass.

It 1 s generally supposed that the Lebanon silt loam is largely derived from rocks which originally lay over the whole western and northern half of the Ozark region. In the western part of the region there lo but little doubt that it is a remnant of the Coal Measure shales and clays that originaliy extended farther east. In the northern part of the region 1t seems to be elther a remnant of Coal measure shales or of glacial clays. In Ripley County the soll is undoubtediy residual of Ilmestone, the latter contalning IIttle or no chert. It is probable therefore that the parent 
material in every case contalned a relatively high per cent of clay which has become more or less mixed with the debris of the typical cherty Ozark rocks.

The Lebanon silt loam is probably the oldest so1l in the State, and has become thoroly leached. Most of the lime and Iron has been removed, much of the latter having accumulated as concretions in the lower subsoll. Moreover, there has been a translocation of much of the finer material from the surface downward into the substratum, which makes the latter heavy and compact. The content of organic matter is low, and the soli is cniy moderately productive. It has, however, a good physical character and with the comparatively smooth topography can be easily cultivated.

Originally the greater part of the Lebanon allt loam, particularly in the western part of the State, was prafrie or open timber land with blue-stem grass. W1th the cessation of the forest fires, a scrub growth of oak quickly grew up, so that now all the noncultivated areas are covered with post oak and brush. In the eastern part of the state red oak is the characteristic timber growth. Probably not more than fifty per cent of the type is in cultivation.

Drainage is inadequate, particularly in the southwestern areas, and the soll remains cold and wet until late in spring. It readily becomes saturated in wet weather, but also dries out quickly as the supply of molsture from below is brought up extremely slowly. 
Corn, hay, and wheat are the principal crops. Corn yields from 10 to 30 bushels per acre, altho occasionally higher yields may be obtained under excentionally good treatment. As a rule the yielos of wheat are not profitable unless fertilizer is used. Hay ylelds from one-half to one ton per acre. Meadows quickly deteriorate, become infested with sedge-grass and briars, and must be renewed about every three years. There is no doubt that the most profitable use of this ocll type is for livestock farming, frobably growing some corn wireat, and oats with fertilization, followed by grass and possibly clover. As a cultivated crop, cowpeas might be included in the rotation.

Chemical analyais-- Lebanon ailt loam

Total Total Total Iime Nitrogen Phosphorus Potassium Requirement

So11 1957 793 26,233 2031

Subso11 1367 785 22,977 2829 
Solls from Limestone, Sandstone, and Shale

\section{Tilo1t S1It Loam}

The Tilait silt loam occurs on the eastern border the ozark region. The most extensive areas are found in Cape Girardeau, Perry, Ste. Genevieve, and Jefferson Counties, but numerous smaller areas too small to show on the soll map occur in all the adjoining counties. In general, the northern areas of the type differ in topography and composition from the southern areas, as will be polnted out in the following paragrapha.

In Cape Girardeau, Perry and St. Francois Counties the typlcal Tllalt silt loam consiats of pale yellowlsh brown silt loam, grading at about six to elght inches into a yellowlsh silt loam or silty clay loam. The lower subsoil is a rather stiff silty clay highly mottled yellow and brown. On the steeper slopes and wherever the underlying sandstone comes near the surface, the surface soll contains more or less fine sand, but such areas are small in extent and of little importance. Freshly plowed flelds have a distinct grayloh or yellowloh appearance, the latter color indicating the eroded areas. Occaslonally chert and sandstone fragments are scattered thru the soll section.

The topogiaphy is gently rolling and, with the exception of a few small areas in western Perry County, is well sulted to cultivation. The surface drainage is thoro. The soll 18 low in organic matter and, largely because of this fact, 
It is easily eroded.

Practically all of the southern half of the type is in cultivation, and is used for corn, wheat, clover, and cowpeas. The yielda are not as large as on the adjoining Hagerstown s011, but are higher than on the Clarksville so1ls. As a rule, little difficulty 18 experienced in getting a stand of clover, except when the supply of organic matter has become largely depleted.

The Tilsit silt loam as found in Jefferson and Ste. Genevieve Countiea is lighter in color and contalns more fine sand than in the areas to the south. Moreover, the surface everywhere is completely dissected, so that much of it is too broken to permit of cultivation. There is practically no smooth land except small areas along the maln watersheds. Probably less than half of this area is cultivated, and the ylelds obtalned average lower than in the southern areas of the type.

The rock from which the Tila1t silt loam is derived is a fine grained sandstone. The bed is rather thin, never exceeding one hundred fifty feet in thickness, and, like all formations of this region, dips eastward. The actual width of outcrops of the rock $1 \mathrm{~s}$ often less than a quarter mile. It formerly extended farther west than it does now, but has been placed in 1 ts present position by the wear and tear of the elements, leaving a great deal of 1 ts material in the so1l as 1t weathered back. The farther from its existing 
outcrop, the less is the amount of sandstone material in the 8011; the nearer to 1t, the greater 1s this amount. The farther away, the more of the materlal from underlying rocks; the nearer, the less of that material. There 1s more or less cradation, therefore, from a soll with a small amount of sandstone material in it in the western and southern parts of the soll areas to one made up wholly or mainly of that materlal lying along the foot of the escarpment and upon its face.

The Tilsit silt loam is an interesting 1llustration of a so11 whose distribution and character are determined by the parent rock (Plate VIII). Since the sandstone from which It is derived weathers at about the same rate as the surroundIng Ilmestones the surface features are the same, but the soil from the former containing less humus and being more porous has been eroded and leached to a greater degree.

Thru a proper rotation with the growing and plowing under of legumlinous crops and the use of manure this soil can be kept in a fairly good state of productivity. The growing of winter cover crops is important in checking erosion on all sloping land. Wheat 18 extensively grown, but the ylelds average smaller than on the adjolning Hagerstown soll. Clover does not make a good growth unless the land is well supplied with organic matter.

Chemlcal Analysis-Tilsit silt loam

Total Total Total Lime Nitrogen Phosphorus Potassium Requirement

So11 1560

820 29,240 240 
$\overline{\bar{\sigma}}$

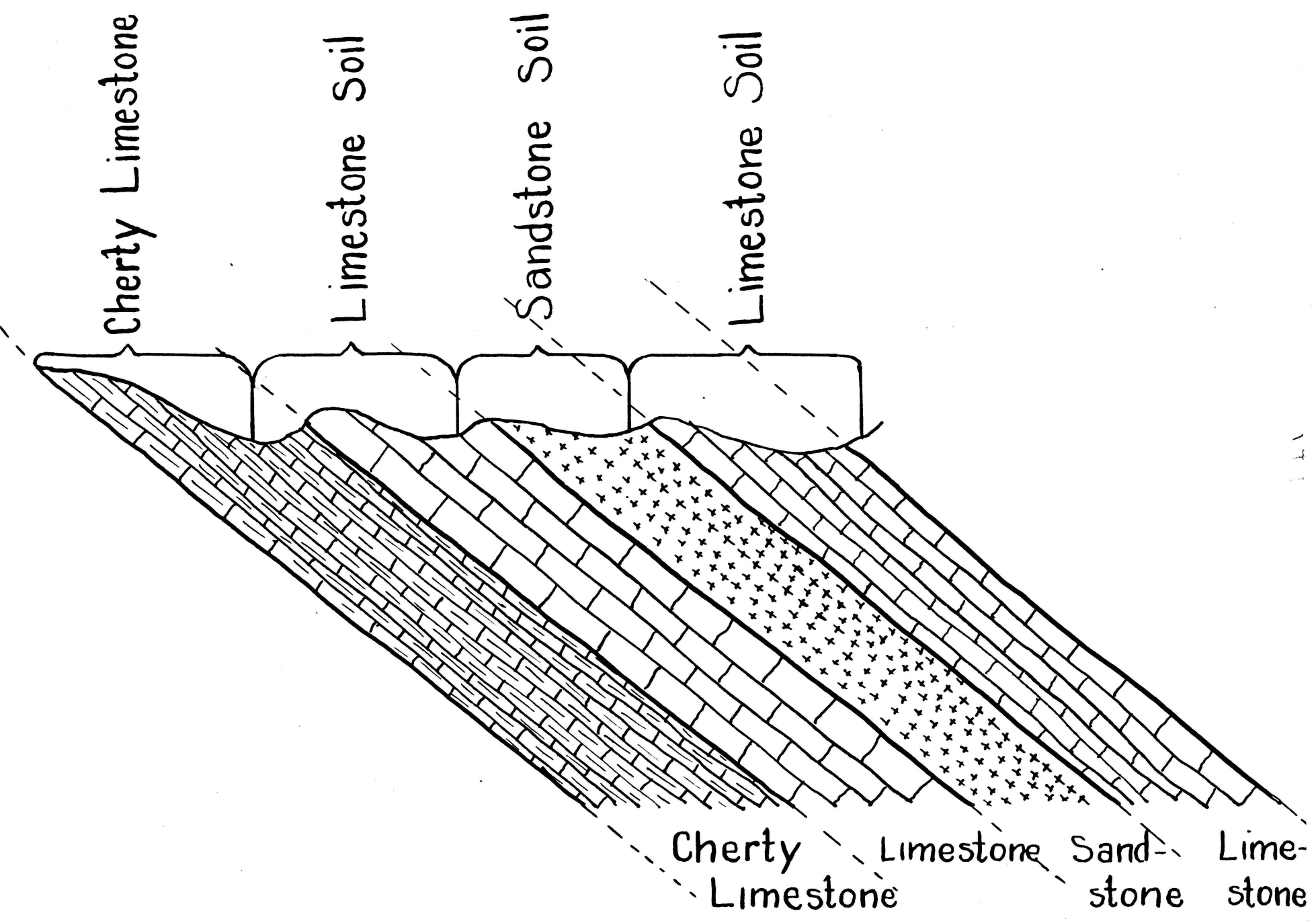

Diagram Showing Variations in

the Soils Due to Weathering of

Rocks (Angle of Dip Greatly Magnified)

Plate VIII 
The above table indicates that the soll contalns a rather high per cent of potassium. The high lime requirement of the subsoll is a characteristic of nearly all solls derived from sandstone.

\section{Boone Loam}

The maln area of the Boone loam lies in Dent County, but numerous areas, either too small in extent or whose boundaries have not been determined, have not been indlcated on the soil map. Several isolated area occur in Douglass, Ozark, and Shannon Counties, and show the rather widespread distribution of the material that gives rise to this soll type.

The surface soll is dominantly a loam, but varies from stony sand to sandy clay loarn in texture, and from light gray to yellowish brown in color. The subsoll is usually heavier than the so1l, and varies in accordance with the materlal from which it is derived. There sandstone is the domInant source, sandy clay or sandy loam preva1ls, but where Ilmestone 1 s the most important parent material the subsoll 1s generally a stony clay. This latter phase occurs around the northeastern and southern borders of the type and along some of the larger valleys. The former occurs in the interior of the area. There is an apparent increase in sandy character southward and eastward. The stones scattered thru the soll and subsoll are never present in sufficient quantity to seriousiy interfere with cultivation. The main area of the Boone loam lies on and near the 
Ozark Divide, and in a locality where the surface has not as yet been deeply dissected. The topography therefore is level to gently rolling and is essentially the same as that of the Lebanon silt loam. The streams are small, and have eroded only shallow valleys with gentle slopes. As soon as enough of the small dralnage channels have united to form one large enough and deep enough to hold a perennial stream It has out beneath the sandstone level into the underlying limestone and into another type of soll. All of the surface, therefore, is of such character as to permit of easy cultivation: The topography of the narrow belts and small areas occurring irregularly over the adjacent region is usually somewhat rougher than that of the main area.

The Boone loam is derived from a medium to coarse gralned brown to reddish brown to gray sandstone, consisting malniy of imperfectly rounded quartz grains with small amounts of chert grains. It 1 o underlain by a very cherty limestone-Gasconade--and in a part of its area is separated into two beds by an interbedded I1mestone.

Black fack and post oak is the prevalling timber growth, altho black oak occurs on the more clayey phase, especlally If it has a reddish color. Originally the greater part of the type was pralrle or open woods, and blue stem grass covered the ent1re surface. At the present time every spot not in cultivation is covered with a growth of oak brush. 
The greater part of the Boone loam is still in timber. Cultivation is confined principally to the valleys and valley slopes. The ridges are rarely cleared. Very little land has been cleared during the last decade, and probably more has been abandoned than has been cleared during this time. This is one of the areas of the Ozark region in which abandoned land is to be found. It has not been abandoned on account of 1 ts being worn out, but because the natural fertility of the soll is so extremely low that farming 1s not profitable.

Altho the so11 is thin, it is not hopeless, and responds to good treatinent. It will not support a prosperous agriculture, but can be made to yield a fair income. A combination of small grain grass, and livestock is the only combination that sults existing natural and artificial conditions in this soll area. Bunch grasses do well, and with liming clover can possibly be made to grow. Of prime importance to make the soll produce fair yields is to supply it with organic matter, and when this is done commerclal fertilizers could be depended upon to increase the crop returns. 
So1ls from Cherty Limestone and Granite

\section{Clarkoville Gravelly Loam}

The Clarkoville gravelly loam is one of the most extensive of the Ozark solls, being exceeded in area only by the Clarksville stony loam. It is closely related to the latter, but differs from it in that the soll is not as cherty and the topography less rugged.

The surface soll to an average depth of elght inches consists of a gray or pale yellow gravelly loam or silt loam. The immediate absoll from a depth of eight inches to about twenty-four inches is a heavy yellowlsh or grayloh brown silt loam which grades downward into a stiff, frlable, reddish brown silty clay. In some cases, especially near the central part of the Ozark region, the entire three foot sect1on 18 marked by gray or yellow colors, but in the vast majority of areas the deeper subsoll is reddish brown in color. The content of chert gravel varies from almost nothing to seventy five per cent, the amount usually increasing with depth. The chert-free or moderately cherty areas border the Lebanon silt loam, or occupy the ridges and divides which closely correspond in position and topography to the latter. As a whole, the chert is more dense and higher in allica than 18 that of the Crawford so1l, but it is not as quartz1t1c In character as that of the Clarksville stony loam. The surface features of the Clarksville gravelly loam vary from almost level to hilly. Where the type surrounds 
the Lebanon silt loam, and in all the southwestern part of the state, the topography is level to gently rolling, but approaching the streams or the Clarksville stony loam the surface becomes more rugged. In Howell County the type Includes the broad shallow valleys, but to the east in Oregon and Ripley Counties the surface is prevallingly hilly. The several areas occurring in St. Francols and the surrounding countles are sharply rolling, bur rarely are the slopes too steep to make cultivation possible. In general, It can safely be sald that the content of rock in the so1l rather than the topography is the Iimiting factor in the ut1lization for agriculture of the Clarksville gravelly loam. The rocks underlying are cherty limestones and magneslan limestones, the latter being the same as those of the Clarksille stony loam. In the southwestern part of the State the cherty Burlington limestone is the parent material. In this region, too, there are remnants of Coal Measure clays that have escaped erosion and have added conslderable fine materlal to the stony mass. Where It is present in considerable quantity it gives rise to areas of Lebanon silt loam. In general the distribution of the calcium limestones is associated with the red subsolls and also a larger amount of clay in the substratum. The native timber growth consisted of the various oaks, with some hickory and wainut. Probably more than fifty per cent of the type. is now cleared and in cultivation. Wuch of the timbered portion is too stony to permit of profitable agriculture, but can be used as woods 
pasture. By removing the brush the pasturage on much of such. land could be greatly improved. Of the cultivated crops corn is the most important, but the yields are low, averaging from fifteen to thirty-five bushels per acre. Wheat does falrly well. Clover makes a good growth if the soll is fairly well supplied with organic matter. As a rule, the best results are obtalned on new land, on north slopea, and on the moderately gravelly areas. Of the grasses, orchard grass is by far the most successful. Apple trees do fairly well, especially on such area as have a deep red subsoll. Strawberrles and other small fruits are commercially grown in the southwestern counties. Peach growing is an important industry in Howell County. In general, the Clarksville gravelly loam can support a falrly prosperous agriculture, altho the initial cost of clearing the land of both rocks and timber is comparativeIy great.

Chemical analysis--Clarksville gravelly losm

Total Total Total Lime N1trogen Phosphorus. Potassium Requirement

So11 1013

393

495

600 22,313 1733

Subso11

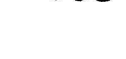

Analysis of the Clarkaville gravelly loam shows the subsoll to be extremely low in nitrogen, due largely to the high per cent of gravel. The content of phosphorus also is 
very low, lower than of any other soll type in the State.

\section{Clarksville Stony I,oam}

The Clarksville stony loam is the most extensive soll type is the State, and Includes approximately one-third of the Ozark region. The maln area occurs in the east-central part of the region, with minor areas bordering all the streams, but in every case this soll type represents rough and stony land, only a very small per cent of which can be utilized for agrioultural purposes.

The greater part of the soll is a gray very stony silt loain with a gray or pale yellowish stony silty clay subsoll. The fine materlal of the lower subsoll is usually reddish brown in color, and a clay in texture. From twenty-five to ninety-nine per cent of the soil mass consists of chert fragments ranging in size from small particles to pleces several feet in diameter. Frequently the surface is so thickly strewn with these fragments that fine soil material is not visible. Rock outcrops are numerous.

On the narrow ridges and on many of the north slopes the soil is a gravelly loam and can be cultivated falriy easily. At the base of long slopes bordering the larger valleys there frequently occur small patches of silty or moderately gravelly'so1l, representing the wash from the hills. Such areas are rather productive and are cultivated, 
but in total area they are of negligible importance. That part of the Clarksville stony loam bordering the White River In Taney and Barry Counties contains comparatively very little chert, and correspondingly more soll materlal, but rock outcrops are so numerous and the surface so broken that the land is non-agrioultural and has been included in the main type.

As a whole, the Clarksville stony loam is the most thoroly dissected land of the Ozark region. The surface consists of narrow ridges, steep slopes, and ravines. The occurrence of even small areas of smooth land is so infrequent as to be practically negligible. The tillable area 18 small and w1ll always remain so, not only on account of the roughness of the topography but also on account of the large amount of stone in the soil.

The rocks giving rise to the Clarksville stony loam consist malnly of very cherty limestones. The resulting 8011 therefore is very stony and such fine material as is formed 1s largely washed away. In general, the rocks in the southern part of the area are more siliceous than in the northern part. The soll in the former region therefore contains more stone, is more porous and drier. It is the region of pine timber.

In general, the Clarksville stony loam is non-agricultural land. It 1s, and should remain, a forest area malniy. Such small farms as have been established within the type represent the valleys or ridges where the stone content is 
smal1. The crops grown are the same as those on the other Ozark so1ls.(Plate IX).

Ashe Stony Loam

The Ashe stony loam probably has the least agricultural value of any so1l type in the state. It occurs in the eastern Ozark region, malnly in Iron, Madison, and St. Francols Countles. Smafler areas occur in several other counties.

The soll is gray, usually very stony silt loam or silty clay with a yellowioh gray clay subsoll, the latter belng full of stones also. The heavler phase as a rule occuples the more level granite areas. It contains comparatively few stones but is difficult to work. In general, the soll mantle in all this type is very shallow, frequently only a few inches in depth or it may be entirely absent. Cultivation is practically impossible. Woreover, such small areas as are smooth enough and stone-free enough to be plowed are not sufficlently productive to make their cultivation profitable.

The rocks underlying the area are lgneous, consisting of granites and rhyolites. The most abundant rock is a dense hard porphyritic trachyte. The grante underlies the smoother areas whlle the peaks are made up of the more resistant porphyry.

Topographically the Ashe stony loam 1s the roughest land in the state. Only a very small part of it is smooth 


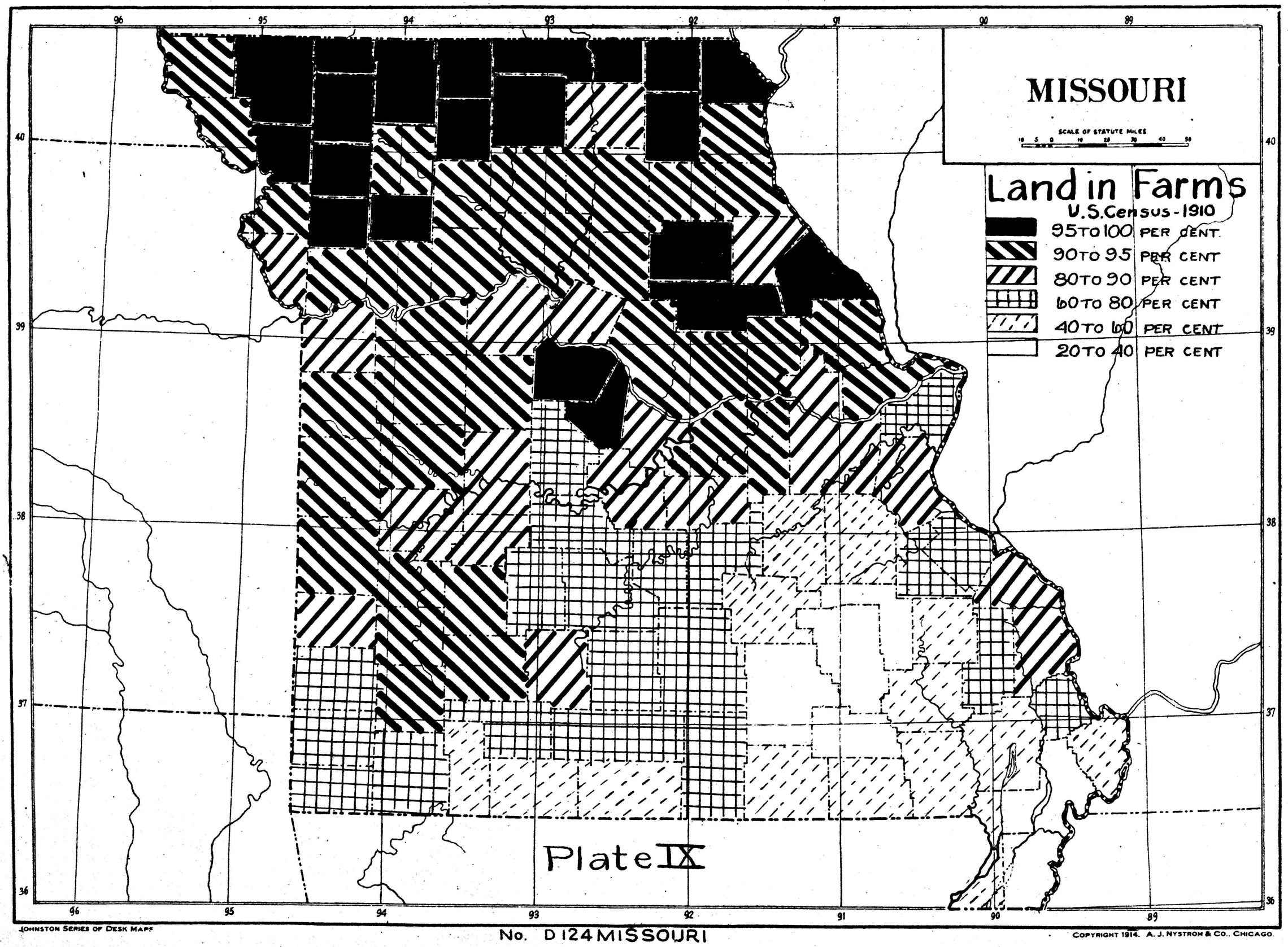


enough to cultivate. The greater part of 1t consists of steep mountain sides, the tops of the peaks being from two hundred to seven hundred feet higher than the adjacent lower country. The valleys are mere gorges, usualIy too narrow for even small fields. As a whole, this type must be consldered practically non-agricultural. l'he whole area, except the small patches that are cultivated, is covered with a growth of black, white, and red oak. Post oak occurs with the others on the smooth areas underlain by granite.

\section{Alluvial Solls}

\section{Hunt1ngton Loam}

The alluvial so1ls of the Ozark region make up a relatively small but nevertheless an important part of the area. It has been estimated $(6)$ that one-fourth of the grain produced is grown on the alluvial solis. In the economy of the region they are therefore of the highest importance. In fact, they are the only soils in large parts of the region on which profitable grain growing can be carried on. This is especially true of the Clarksville otony loam area, and the rougher parts of the Clarksville gravelly loam. Even along the largest streams the belt of alluvial land does not average more than one-fourth mile in width, and usually much less than this.

The Huntington loam has been made to include all the 
alluvial land, since the latter is predominantly a loam in texture altho it also includes gravelly loams and silt loams. In color it is brown, reddish brown to dark brown, but gray to nearly white soll occurs, the latter representing terraces of limited distribution. In the region of the Clarksville stony loarn, and along many of the small streams, it is gravelly as a rule, the gravel consioting wholly of chert. Bordering the stream the soil is almost universally a loam or fine sandy loam. In the wide valleys and back from the stream the texture is usually a silt loam.

There is usually very little difference in the physlcal properties of soll and subsoll. The latter is invariably of a light texture, and frequently is sandy or graveliy in the lower portion. This is but natural, since all the streams flow at rather steep gradient and deposit only coarse material. Taken as a whole, the Huntington loam does not stand drought very well, especially in areas coarser than a loam. However, the water table usually lles sufficiently near to the surface to be in reach of deep-root1ng crops, and total crop fallures are of rare occurrence. The Huntington loam is alluvial in origin except in the narrow valleys where it 18 partly colluvial. The material is derived from the cherty limestone s011s w1th an admixture of more or less sand from the thin sandstone beds. The surface is level, altho there are many shallow depreasions 
and abandoned channels that are frequently deep enough to limit the size of the flelds. All of the type is subject to overflow, but inundations are of short duration, rarely lasting more than two or three days.

Practically all of the Huntington loam is in cultivation. It was the first to be settled and in large areas of country It 18 yet practically the only soll that is cultivated. Corn is the most important crop, and the high average jields obtalned attest to the high fertility of this type. Wheat, clover, alfalfa, and grasses all thrive exceedingly well. A very small acreage 1s used for pasture purposes, as the less fertile hillo adjolning supply sufficient grass for this purpose. Rarely is an attempt made to build up the land by the use of manures or fertilizers, since these materials bring larger returns when applied to the upland solls.

Chemical analyois--Huntington silt loam

Total Total Total Lime Nitrogen Phosphorus Potassium Requirement

So11

Subso11 1820

1400

1176

1135

24,875

25,580

782 1437 
Southeast Lowland So1ls

General Description

The Southeast Lowlands present one of the most varied and interesting soll areas in Missourl. Altho all the so1lo are of aliuvial origin, they are unlike the alluvial soils in other parts of the state. The latter recelve new soil materlal at each overflow, and are therefore st1ll in the process of formation. Their characteristics are not fixed, but are subject to change. The so1ls of the Lowlands, altho for the most part subject to overflow, do not--exceptIng along the Mississippi River--receive new soll deposits. The overflow water consists of local ralnfall, and of water from the upland streams. The latter, as a rule, has lost 1ts load before entering the Lowland or immediately after dolng so, and thus add no new soll material. The Lowland so1ls may therefore be said to be statio in their character1stics, and in this respect are like upland so1ls.

The deposits from which the Lowland so1ls are derived have been brought down by the Mis818sippl and other large rivers, and are therefore of complex origin. They represent material from the Great Plains, the Glacial and Loessal Pralries, and residual uplands together with varying amounts of organio matter. It is only along the edge of the uplands and at the debouche of the small streams that the 8011 is largely of local origin. It 18 more than probable that the 
alluvial lands between Crowley's Ridge and the main upland consists largely of loessal material washed down from the adjoining uplands (particularly Crowley's Ridge) and is therefore more homogenous in source than are the alluvial lands east of the Ridge. The rather remarkable uniformity and fine texture of the so1l indicate strongly that it consists of reworked loess. Moreover, the simflarity of the alluvial soll along the streams within Crowley's Ridge to the main body of alluvial lands west of the Ridge is almost conclusive evidence that they are of similar and therefore largely of local origin.

Altho all the Lowland solls have been formed by stream action, the deposition of the soll material occurred under varled conditions of stream flow. Such areas as were aubject to. frequent overflow with swift current consist of sandy s011s, while areas of slow flowing or standing water consist of silt and clay loams. This 18 due to the checking of the current upon leaving the main channel, which causes the coarser particles to be deposited first, while the clay, silt and finer sand are carrled farther back and lald down in the more quiet waters. The occurrenoe of the extensive area of sandy so1I bordering the Mississippl river is therefore eas1Iy explained. This area in the northern part, within the bend of the river, is much wider than in the southern part where the river flows in an almost stralght line. The belt of heavy solls extending from near Cape Girar- 
deau to the Arkansas State Ine represents the old river channel. Being closed at 1 to upper end, it recelved only slow flowing water which carried only fine material in suspension. The process of bullding up was a slow one, and ample time permitted the growth of rank vegetation. The decay of the latter incorporated a large amount of organic matter and gave the soll a dark color. On the front or sandy lands, vegetation grew well but decayed much faster, so that not so much organic matter was incorporated with the so1l, leaving It as a rule lighter colored.

The second bottoms include the sand ridge in Dunklin and Stoddard Counties, and Sikeston Ridge in Scott and New Madrid Counties. These two areas represent old river banks, and therefore owe their coarse texture to similar causes now acting along the present banks of the Mississippl River.

'the pronounced color differences of the several Lowland so1ls 18 of interest not only to the student of solls, but also to the farmer who usea it as a basis for determining the relative productiveness of the soll. In general, these color differences are due to differences in molsture, degree of weathering and age of the soll material.

The dark color of the clay and sandy land has already been referred to. In the case of the second bottom or ridge s0118, on account of their greater age, better drainage and open texture, oxldation and leaching have progressed to such a degree that most of the humates have disappeared, and the Iron is so completely oxidized that it has imparted to the 
so1l a characteristic brown color. The color of the oxldized Iron has taken the ascendency over the dark color due to the organic matter. Weathering has been more complete than on better drained first bottom solls.

'the lowland s011s west of Crowley's Ridge represent the old valley, of the M1ssissippl River. They are therefore very old--much older than the s011s east of the RIdge, and are probably as old as the oldest Ozark s011s. Their great age and poor drainage has caused excessive leaching, with the 108s of Iron, lime, and even phosphorus.

Coffey (9) states that "If a so11 is low in lime, intermittent wet and dry conditions will cause it to turn white and markediy decrease in productiveness, while if lime is present 1t w1Il become much darker and an increase in productiveness will take place."

The removal of the 1ron, or at least the leaching of It from the upper soll to the lower strata, is cause also for the gray color of the soll, and for the presence of the numerous concretions in the subso11. Noreover, on account of age and leaching and the low lime and organic content, there has been a greater translocation of the finer particles from the surface downward. As a matter of fact, these gray so1ls are the only alluvial solls that show stratification, altho they are replenished in the surface by additons of materlal to a greater extent than the other Lowland types. The color of these Lowland so1ls is therefore of great sig- 
nfficance, as it indicates their age, drainage condition, and relative amount of leaching and loss of fertility they have undergone.

In general, the sandy solis of this region contain enough of the finer soll particles to make them loamy, while the heaviest clays are more easily managed than aticky clay s011s of other parts of the State. Of the dark colored so1ls but Iittle difference is observed between the fertility of the heavier and lighter loams. A few cypress brakes have a surface soll of muck or humus on top of the alluvium. Such areas are of nearly inexhaustible fertility, but their total area is small..

On the basis of color and textural differences, the so1ls of the Lowlanderegion have been separated into s1x types, belonglng to four serles. Only the prevaling characteristics of each type are here described, for the variations within each type are innumerable. Moreover, they are not as Important agriculturally as in upland s01ls, owling prinolpaliy to the much shallower depth of the water table and the relatively larger amount of organic matter. Both of these factors tend to diminish the effect of differences in texture upon the molsture relations of the so1l.

\section{Sarpy Fine Sandy Loam}

The Sarpy fine sandy loam represents the extensive frontal land along the Mississippi River in the Lowland region. It Includes all of MIssissippl County, and the eastern part 
of Scott, New Madrid, and Pemiscot Counties.

The texture of the Sarpy fine sandy loam ranges from fine sand to very fine sandy loam with included areas of loam, silt loam, and clay, but prevallingly is a fine sandy loam or loam to the extent of more than elghty per cent of the type. The color varies from brown, thru gray to black, with all intermediate shades. Probably the most persistent and distingulahing characterlatic of the type is the texture of the subso11, the latter being almost without exception a graylah brown fine sandy loam. The depth of the surface so11 Is about twelve to elghteen inches. In general, there is no IIne of demarcation between s011 and subso11, and the only apparent difference is the somewhat lighter color and texture of the latter. It 18 of special interest to note that while all this sandy soll consists largely of rather fine sand it contains a large amount of silt, so that it is coherent and can retain a fair amount of molsture.

Probably the most consplcuous variation of the type occurs in Scott and M1ssissippl Counties. Here are found large areas of fine sand, which do not contain enough fine material to bind the soll particles, and are therefore subject to "blowing" during dry seasons. This condition has been aggravated in recent years due to the continued cultivation of the land and the consequent burning out of the organic matter which acts as a soll binder. 
Thruout the area of the Sarpy fine sandy loam, exceptIng the higher land adjacent to the river, are small mounds of sand called 'sand blows''. These, where they have been undisturbed by cultivation, range in diameter from 8 or 10 to 50 feet or more, and in height from only a few inches to thirty-81x inches or more. They are elongated, and have a northeast-southwest trend, which indicates their origin from owift flowing water in time of high overflow. The material of these mounds is largely quartz sand, medium to coarse in texture, and averaging coarser and sharper than that of the surrounding so11. They probably result from the gathering of the sand in clumps of bushes or trees.

The Sarpy fine andy loam owes 1ts origin to comparatively recent deposition of fine sandy sediments from Missisalppl River overflows. During the period of formation there remained innumerable old stream beds, bayous, and sloughs that carried water only at times of overflow. The natural levess bullt up along the banks of these old channels, like the banks along the river, not only caused the great variation in the so11, but also made the surface uneren. The banks form the low sandy ridges. The greater depth of water in the depressions, and their longer sukmergence under such conditions, account for the greater accumulation of fine mater1al on the lower ground. Th1s, in part, explains the variableness in texture and color of this soll type. The darker 
color 18, as a rule, assoclated with the heavier soll.

The Sarpy fine sandy loam seems to carry a high proportion of avallable plant food in spite of the fact that the open porous character of the 8011 does not offer conditions favorable to the accumulation of much organic matter. The light so1l and sandy substratum facilitate drainage, allowIng this "land to be worked soon after a rain. The water table rarely comes near enough to the surface, even at high stages of the river, to serlously affect crops. With the exceptions of the very sandy areas and some of the sandy ridges, the depth and fineness of the soll is sufficient to retain enough molsture to meet the demands of a growing crop in any short period of drought. There 18, doubtless, more or less caplliarity between the root bearing layer and the permanently saturated substratum of sand, so that droughty conditions in a properly tilled fleld are rarely serious.

In general, the whole of the Sarpy fine sandy loam 18 under cultivation and Includes some of the most improved land in the Lowland region. Varlous reasons may be given for this. Bordering the river, it was the first to be settled by the early imigrants, who did not venture far Inland from the large streams. In general, dralnage conditions are better than on the so1ls to the west, and the construction of costly drainage channels was not necessary before the land could be cultivated. The light texture 
and high fertility of the soll made cultivation easy and profitable.

All of the crops common to the region are successfulIy grown on the Sarpy fine oandy loam. In Scott and Misslssippl Countles corn, wheat, cowpeas and alfalfa are the staples, while melons, sunflowers, and peanuts make up the special crops. In Pemiscot and the southern part of New Madrid Countles corn, cotton and alfalfa are extensively grown. Cotton is mostly confined to the lighter so11. Excepting on very sandy areas, the Sarpy so1ls are especialIy well adapted to alfalfa. The deep, porous subsolls perm1t of good root development to great depth. Probably no other seotion of Missourl has made such rapld development during the last decade as the region of Sarpy s011s. The value of all farm property in Pemlscot County from 1900 to 1910 increased more than 263 per cent. The influx of farmer has been mostly from the northern states. These men have brought with them the most improved type of agr1culture which is rapldiy replacing the indifferent and extravagent methods of the early settlers.

\section{Iintonia Series}

Iintonia Silt Loam

The area of Iintonia silt loam forms one of the most pronounced physlographic divisions of the Lowland region-Sikeston Ridge. The latter, extending from near the center 
of Scott County to New Nadrid in the same county, varies in widh from three miles near the notthern end to six miles near the southern extremity. On the west side the ridge 1s marked by an abrupt offset of twenty to thirty feet to the bottoms, but on the east it grades rather gradually into the Sarpy so118.

The surface so11 of the Lintonla silt loam in general consists of a brown, dark brown or grayish brown silt loam to fine sandy loam to an average depth of ten to fifteen inches. The subsoll is a light brown to graylsh brown silt loam or silty clay, mottled brown and gray in the lower portion. The lower subsoil is nearly always a silty clay with some sand. In general, the soll on the west side of the ridge is siltier than on the east side. Numerous areas of sandy s011, in some respects resembling the "'sand blows"' of the Sarpy s0118, and varying in extent from a few square rods to several acres, are found thruout the ridge. The sandy surface so11 is usually assoclated with a sandy sub8011, but in many places the latter 1s almost sand free. The occasional shallow pond-like depreselons, and shallow swalls and abundant bayous, have light gray surface so1ls with gray or drab clay subsoila. The light color of the so11 is due to inadequate aeration and almost constant saturation during rainy seasons. These areas are much inferIor to the main type, and resemble the Waverly solls. The Intonia silt loam is alluvial in origin, having 
been deposited by streams when flowing at higher levelo. The soll material represents outwash from the loess hills, probably from Scott and Cape Girardeau Counties, which became intermingled with sand during the process of deposition. The soll 1s loamier, and the subsoll not so compact as that of the hill so1ls, which affects to some extent 1ts molsture holding capacity. In some of the exposed cuts and banks the soll material resembles in every way the typical loess deposits, and were it not for the intermixed sand and evidences of stratification in the substratum, this soll could not be distingulshed from the upland.

On account of the relatively high position and sandy substratum both surface and under-drainage are good. Aeration is effective to great depths, and this is doubtiess the chlef cause of the high degree of oxidation of the ferruginas minerals, and the rapid decay and rather slight accumulation of organic matter in the soll.

The Intonia silt loam is one of the oldest, if not the oldest, settled so1I in the State. New Madrid, founded in 1764, is located on 1t. A large area of the type is divided into grants which were donated to the early settlers during the Spanish regime. Cotton, corn, and wheat were the principal crops, but of these cotton is no longer grown. With the decrease in the fertility of the soil there has been a reduction in the acreage of corn, and small grains, clover, cowpeas, and grass are now the most important crops. In general, the Intonia silt loam is a highly desirable soll 
for general farming, but its efficlency could be greatiy increased by addition of organic matter of which it is greatly in need.

It represents the highest priced land in the Lowland region. The prevalling price is $\$ 100$ to $\$ 150$ per acre, but sales at $\$ 250$ per acre have been made. These high values are due not only to the desirable physical properties of the s011, good drainage, and transportation faclities, but because much of the land 18 held by wealthy owners who have given it a high social value.

\section{Lintonia Fine Sandy Loam}

The Lintonia fine sandy loam, like the Lintonia silt loam, represents a distinct physiographic area of the Lowland region--Dunklin sand ridge. The latter begins near Dexter in Stoddard County and extends south thru Dunkin County to the Arkansas State line. In the northern part It varies from four to $81 \times$ miles in width, but south of Kennett it is twelve to fourteen miles wide. As already stated, this ridge is a second bottom, standing from ten to twenty-five feet above the first bottom to the east. On the west it is bordered by Crowley's Ridge and the first bottoms along the St. Francois River. Numerous other small areas of the type occur in Ripley County and the northern part of Stoddard County, but only those in the latter location are of oufficient extent to show on the B011 map. 
The Lintonia fine sandy loam is dominantly a fine sandy loam, altho included in it are areas of fine sand and loam. The surface soll varies from twelve to twenty inches In depth and is of a brown or dark brown color. The subsoll Is very simflar to the surface so1l, but usually is somewhat lighter in color and contains slightly more clay--especially in the lower portion.

In general, the Iintonla fine sandy loam becomes heavier from east to west. Along the eastern edge of the ridge the so11 is a brown, loose, incoherent fine sand of about the same texture and color thruout the soil section. It contains so little fine material and 18 so loose that it is subject to drifting or blowing. To the west of this light sandy phase, the typlcal fine sandy loam prevalls. It consists of a dark brown fine sandy loam, underlain at about twenty to twentyfour inches by a yellowish brown frlable silty clay or fine sandy clay subsoll. Along the western edge of the ridge the heavy subsoli lies somewhat nearer the surface, and 1s lighter in color, due to poorer drainage. The heavler texture of the subsoil is no doubt due to filtration, a process that readily occurs in such open s01ls. However, the relat1vely small amount of material that is of a clay texture explains why the subsoll is rarely heavier than a silty clay, and 18 comparatively heaviest where the surface soll contains a higher per cent of fine material.

Probably the most pronounced characteristic of the linton1a so1ls is their distinct brown color. This is due to the 
high degree of oxidation of the soll material associated with good aeration and drainage. For the same reasons the content of organic matter is not very large and is not present in sufflclent quantity to conceal the brown coloration of the so11 particles. In this respect the Lintonia fine sandy loam differs from the Sarpy soll of the same texture. The latter, on account of a higher per cent of fine material, and existIng under poorer dralnage conditions, contalns a much larger amount of organic matter, and is not as thoroly oxidized as the former. It is possible, too, that this difference is aggravated somewhat by the greater age of the Lintonia so1l. The surface of the Lintonia fine sandy loam is nearly level with the exception of faint undulations which are hardIy noticeable. In perspective. Slight mounds and low ridges from a few Inches to several feet in helght occur, as well as slight depressions, generally old overflow channels. The so11 in the latter is a gray loam with gray sandy clay subso1 1 , mottled brown and gray. In origin the Lintonia fine sandy loam is the same as the silt loam type. Dralnage is good except in the swales, found most extensively in the western part of the type.

Like the Sikeston Ridge, the Dunklin sand ridge has been settled and farmed for a long time. Cotton is by far the most important crop and the acreage devoted to it is probably greater than that on any other Lorland type. Ylelds range from one-half to one and one-half bales per acre. The qualIty of the lint 18 of high grade. Corn, cowpeas, olover, 
and melons are extensively grown. Alfalfa thrives where dralnage conditions are good and the soll not too coarse in texture. Potatoes, peanuts, truck, and other crops which require a warm light so12 are successfully grown.

Chemical analysis--Lintonia sandy loam

$\begin{array}{cccc}\begin{array}{c}\text { Total } \\ \text { Nitrogen }\end{array} & \begin{array}{c}\text { Total } \\ \text { Phosphorus }\end{array} & \begin{array}{c}\text { Total } \\ \text { Potassium }\end{array} & \begin{array}{c}\text { Lime } \\ \text { Requirement }\end{array} \\ 1791 & 1054 & - & 858 \\ 1190 & 1065 & -\ldots & 1562 \\ 960 & 1012 & -\ldots- & 1080\end{array}$

The so1l has lost much of 1ts original fertility, especlally where cotton has been grown many years in succession and no organic matter supplied. The necessity of growing legumes and winter cover crops for green manures is being realized. Commercial fertilizers are used to some extent-usually for melons. The very sandy areas are not drought resistant, and frequently crops suffer.

\section{Sharkey Clay Loam}

The Sharkey clay loam forms the belt of heavy soll extending from the southern part of Cape Girardeau County to the State line along the south side of Pemiscot and Dunklin Counties. Thls area is frequently known as the Ilttle River Valley. It undoubtedly represents the old channel of the Mississippl River before this stream shifted Its course to the present position. (17) It is but to be ex+ 
pected that the so1ls of such a large area have considerable variation, and only the main soil characteristics can here be described.

The typlcal Sharkey clay loam consists of a black, drab or dark gray silty clay to clay loam, underlain at depths varying from elght to fifteen inches by drab to blulsh gray, heavy, plastic clay loam or sandy clay, usually mottled with rusty brown. The gradation from so1l to subsoll is not distinct, and frequently there is little change in color or texture thruout the so11 section. The surface so11 contains a rather large amount of organic matter, which makes it falrly friable. The immediate surface two or three inches almost everywhere contain a small amount of sand, which in places is present in sufficlent quantity to give a loamy texture. The subsoll in general is quite unfform, altho sand or sandy clay is encountered in places. Such areas represent an approach to the Waverly s012s. The close structure of the subsoll makes aeration imperfect, resulting in only a faint development of brown mottlings, but wherever these extend to a depth of two feet or more there is a decided tendency of the material to be granular. Such a condition 1s preferable to that where the light bluish gray coloration prevalls, for in the latter the underdrainage is extremely slow, altho in no instance does the material seem to be entirely impervious. On the outer border of the areas of Sharkey clay the depth to the sandy substratum 18 not more than a few feet, but in the interior, where the accumulations 
of olay are deeper, the depth to coarse textured material is correspondingly greater.

In the southern part of Stoddard County and in New Madrid County, much of the Sharkey clay. Ioam occuples the wide shallow swales or depressions, varying from a few rods to one or more miles in wiath. The soll in these is a deep, black, waxy clay loam with black to bluish black clay subs011. It consists of the finest sediment, and contains from 50 to 65 per cent of clay and from 30 to 40 per cent of s1lt. The content of organic matter 1s considerably higher than for the type as a whole, and in restricted areas-along east side of Dunklin sand ridge, west slde of Sikeston ridge, and northern part of Stoddard County--1s almost a muck s011. These black soll areas, usually extend in a north and south direction, and represent the lowest land in the entire Lowland region. They possess almost true swamp characteristice, and are for the most part subject to prolonged overflows and even serve as natural drainage ways. The timber growth consists of cypress, ash, and tupulo gum almost exclusively. Such areas as have been drained have proven exceedingly productive, and are used for corn almost exolusirely.

In general, the Sharkey clay loam in Cape Girardeau, Stoddard, and Scott Countles averages darker in color and contains more organic matter than the area to the south. Th1s 1s probably due to the more recent deposits brought 
down by the streams from the upland. In many respects this dark so1I is I1ke the Wabash soll in the northern part of the State. In most instances the transition from the Sharkey clay to the IIghter so11s on the east is marked by numerous small sand and silty ridges surrounded by moderately heavy 8011. Such phases are higher, more easily tilled, and considerably earlier than the lower ground.

'ihe Sharkey clay loam is a much easier cultivated so11 than the Wabash clay loam. As a rule the soil loses much of 1ts "stickyness" after being cultivated a few years, due to a decrease or at least a change in the organic matter. If properly handled in the field it mellows down and assumes the tilth of a heary silt loam. Cultivation can be performed with comparative ease under a much wider range of molsture conditions than on most so11s of corresponding texture. If plowed wet it becomes hard and intractable, yet $1 t$ will mellow down with alternate wetting and drying in the early spring, so that no trouble will ordinarily be had in securing good tilth.

The surface is flat to slightly hummocky, but frequentIy there is very little or no difference between the soll on the hummocks and in the depressions. Looally the Sharkey clay loam 18 termed 'swamp'' because most of it is subject to annual overflow from water which comes in from the Ozark streams. Drainage 18 necessary before the land 
can be cultivated. Many ditches have already been constructed, and with the completion of all the proposed drainage all of the type can be ut1lized. There is no doubt but that in time this vast area of heary soll will be as valuable and as productive as any part of the Lowland region.

In 1ts natural fertility the Sharkey clay loam is probably on a par with the Wabash solls. Practically all of the cultivated land is used for corn production, and the yields obtained indicate the adaptability of the soll to this crop. As a grass soll it is superior to any of the Lowland types. Red clover, alfalfa, and various forage crops have been tried to a limited extent with good results. In farorable seasons, cotton ylelds from one to two bales per acre, but frequently the plants make such a rank vegetative growth that they do not mature properly before the early fall frosts. Portions of the type are well adapted to the production of rioe.

Land values are determined largely by the molsture conditions. Undrained, cut-over timber land is held at $\$ 20$ to $\$ 40$ per acre. Drained and cultivated land sells at $\$ 50$ to $\$ 90$ per acre. Practically all of the land is subject to drainage tax varying from twenty cents to one dollar per acre per annum, such taxes usually running for a perlod of twenty years.

Chemical analysis--Sharkey clay loam

Total Total Total Iime N1trogen Phosphorus Potassium Requirement

$\begin{array}{llllr}\text { So1I } & 4355 & 2855 & 36,820 & 1750 \\ \text { Subsurface } & 1753 & 1826 & \ldots \ldots & 116 \\ \text { Subs01I } & 1600 & 1620 & 39,460 & 0\end{array}$


From this table it will be seen that the total amount of plant food in this soil is as high as in the alluvial soil of north Missouri. The content of potassium is especially high. The greater lime requirement of the surface soll would Indicate that the acldity is due to organic materlal.

\section{Waverly Sollo}

Waver Iy S1It Loam

The Waverly silt loam Includes practlcally all of the western part of the Lowland region between Crowley's Ridge and the main body of the upland. The type is easily distingulshed from the other alluvial so1ls by the light color and silty texture of the so1l, and the smaller timber growth. The latter consists primarliy of oak, elm, and hickory, but contains little gum, cypress, ash, catalpa, or hackberry so characteristio of the east Lowlands. Included in the Waverly silt loam are members of the closely related Calhoun and olivier serles.

The typical so11 is a light gray to dark gray compact silt loam or silty clay, faintly mottled with rusty brown colors, which grades at a depth of six to ten inches into a light gray to white silt loam also mottled and containing small iron concretions. The subsoll below fifteen to elghteen Inches is almost unfformly a gray or drab, plastic, impervious silty clay or clay, mottled with brown and yellow. 
Where the surface so1I is a silt loam the heavy subso1l is not reached unt1l about twenty-four inches, but where the surface averages a silty clay the subsoll is correspondingIy heavier, and generaliy lies within fifteen inches of the surface. The gray subsurface layer is always present and is most highly developed in the silty s011, but may be absent or only faintly developed in the heavier areas. That portion of the Waverly silt loam lying between the northern part of Crowley's Ridge and the main upland consists largely of recent alluvium, having been brought down by the Ozark streams that enter the Lowland at this place. The soll 18 silty to a great depth, contains a large amount of organio matter, and in general does not have the weathered appearance of the older solis to the south. Much of this area possesses almost true swamp characteristics, having a light floating soll or mud frorn a few Inches to several feet in depth. The outer edge of these bogo is covered with cypress and ash, but in the center they are elther open water or are covered with flags and water loving grasses. When dralned the soil will be the same as the surrounding Waverly silt loam, but w1Il contain a much higher percentage of organic matter.

Thruout the Waverly silt loam, particularly near Crowley's Rldge, there are places where the surface so1I to varyIng depth is brown like that of the Iintonia so118. Where these areas are small and shallow they are always underlain 
by the characteristic gray and heavy subsold of the Waverly. Other areas, usually shallow basins, carry so many iron concretions on the surface and thruout the so11 section that they are called 'gravelly crayfish land'. Along the St. Francols and Black Rivers are many hummocks or low elongated ridges of a brownlsh sandy loam similar to the Lintonia soll. The main portion of the Waverly silt loam must be considered a terrace soll which was formed in 1dentically the same way, at the same altitude, and probably at the same time as the Lintonia so11s. The so11s of the two series are vastIy different, however, due to the character of the material deposited, and the molsture conditions under which it existed. There is no question but that the Waverly silt loam is largely of local origin, washed down from the adjoining uplands, and therefore consists of reworked loess. Th1s explains the uniformly fine texture of the s011, and the relatively higher altitude of the land near Crowley's Ridge. It is also correct to assume that the alluvial deposits and especially the wash from the upland did not have the characteristics that the so1I now has.

These changes were brought about by poor drainage and the consequent leaching and filtration of the clay particles in the lower subsoll. The alternate wetting and drying of the so11 in the presence of decaying organic matter is directly the cause of the gray color and the abundance of Iron oxide conoretions, normal oxidation, which in this re- 
gion gives a unfform brown color to a soll, having been inhibited by the very poor aeration. The surface soll is I1ghter colored--white when dry--in those places where the subsoll is heaviest and most intractable. The accumulation of iron in the substratum in many places cemented the so11 particles and formed a hardpan. Probably no other so1I in the State has so well developed a tendency toward hardpan as does the Waverly silt loam, and the only plausible reason for this is that described above.

It is the prevaling opinion among farmers that when this soil is drained and thoroly cultivated it becomes darker in color, more friable and more productive. Th1s, no doubt, is due to the better aeration and consequent oxidation.

It is but natural that a soll so thoroly leached should show an acid condition, particularly in the surface soll. Less than fifty per cent of the Waverly silt loam is cleared and in cultivation. Large areas as yet remain undrained, and not until drainage is provided can the land be cultivated. In years of nornal ralnfall fair to good returns are obtained from corn and wheat, but damage occasioned by wet seasons lowers the average yleld considerably. It can not be considered a good corn so1l, but 18 best adapted to wheat, peas, and grass, and it is on these crops that the future agriculture of the type will probably depend. A very small acreage of cotton and clover is grown. Attempts at growing rice have been successful, and it is probable that this Industry can be extended with profit. 
Chem1cal Analysis

Waverly S1It Loam

Total

Total Total

Iime

N1trogen Phosphorus Potassium Requirement

So11

1764

1556

24,520

4088

Subsurface

1013

1800

3166

Subso11

956

1360

- - -

2408

Waverly Clay Loam

$\begin{array}{lrrrr}\text { So11 } & 2588 & 1040 & 25,780 & 2740 \\ \text { Subsurface } & 1150 & 680 & -\ldots & 0 \\ \text { Subs011 } & 908 & 1024 & 23,400 & 288\end{array}$

Calhoun Clay Loam

$\begin{array}{lrrrr}\text { Soll } & 1980 & 1032 & 27,180 & 5020 \\ \text { Subsurface } & 1246 & 1020 & -\ldots & 6000 \\ \text { Subs011 } & 1780 & 955 & 24,940 & 5344\end{array}$

Waverly Fine Sandy Loam

The Waverly fine sandy loam is found in Stoddard County east of Crowley's Ridge, and the southeastern part of Ripley County. It consists of a graylsh brown to yellowish gray Ine sandy loam to very fine sandy loam, grading at about elght to-trelve inches into yellowish brown, compact, fine sandy loam. The subsoll from elghteen to thirty-81x inches 
Is fine sandy clay--sometimes more or less stratifled as sandy and clay layers. The Ripley County area averages considerably lighter in color than the Stoddard area, and usually shows a rather distinct demarkation between s01I, subsurface, and subso11. The latter contains many iron concretions, and in places has true hardpan cementation in the lower portion. The surface soll has a tendency to become compact and form a crust, and when in this condition appears much heavier than it really 18.

The Waverly fine sandy loam includes slight rises or ridges that stand as much as one to three feet above the lowest land. These are the natural levees along the present bayous or the remnants of former stream fronts. That portion of the type in Stoddard County 18 first bottom and probably was deposited when the Sharkey so1l was formed. The Ripley County area is undoubtedly of the same age as the Waverly silt loam, and existing under similar conditions has become thoroly leached. Most of this area if subject to annual overflow which comes in from Black Biver.

It Stoddard County all of the type has been drained, and 18 in cultivation. It is a good agricultural so1I well sulted to corn, cotton, and forage crops. Wheat is extensively grown and averages 18 to 25 bushels per acre. Clover and cowpeas do well when the soll is thoroly drained. Potatoes and various truck crops are successfully grown. The Ripley County area of the Waverly fine sandy loam 
is now being drained and will be cleared within a few years. Cultivated areas are used for corn, timothy, and cowpeas. The ylelds are much lower than in Stoddard County, due to poorer dralnage and the very acid condition of the soll. The hardpan in the lower subsoll tends to keep the soll saturated with water and thus makes 1 t cold and difficult to handle.

Chemical analysis--Waverly loam and fine sandy loam

$\begin{array}{lcccc} & \begin{array}{c}\text { Total } \\ \text { Nitrogen }\end{array} & \begin{array}{c}\text { Total } \\ \text { Phosphorus }\end{array} & \begin{array}{c}\text { Total } \\ \text { Potassium }\end{array} & \begin{array}{c}\text { Lime } \\ \text { Requirement }\end{array} \\ \text { So11 } & 2026 & 1813 & 22,250 & 3216 \\ \text { Subsurface } & 1393 & 2126 & --1- & 833 \\ \text { Subso11 } & 803 & 1610 & 22,253 & 656\end{array}$




\section{General Consideration}

The discussion of the Solls of Missourl has been confired in this thesis to twenty-eight types, each of which represents as nearly as possible uniform conditions as to its origin, physical properties and agricultural value. It is obvious that in an area so large as Missour1, with a great complexity of soll conditions, each type must include varlations, but in general these have no special importance in determining the adaptation or utilization of the soil as a whole. Because of the great area of these few types, because each so12 is preeminently adapted to the production of some great staple crop or group of such crops, and because each soll possesses particular problems in its management, the agriculture of the State is influenced more by such homogeneous soll areas than by a diversity of minor types.

Agriculture is still a generalized business, altho its specialization into horticulture, market gardening, and other subdivialons has begun. With increasing population, with greater intensity of cultivation, greater demands will continually be made upon the soll and greater precision and skill in the selection and handing of solis for special crops will be required. The so1l factor which governs plant and crop growth must therefore be understood and appreclated. The fact 
that each crop has varieties sulted to different solis must recelve more recognition. The problem of maintaining and ever increasing the producing capacity of the agricultural lands, while they are probably economic and farm management problems to a certain extent, are only capable of solution after a thoro study of soll conditions in the fleld. Moreover, such studies can not be confined to small areas of only a few acres in extent, but must cover the entire region under consideration.

In general, the soils of Missourl are capable to a greater or less degree of further extension elther of cultivated area or of more diversified, more intensive, and more profitable agricultural occupation. Of the Ozark so1ls, less than one-fourth the total area is in cultivation. However, further development waits upon the solution of economic problems rather than upon the discovery of suitable methods of their utilization. It is primarily upon the so1ls that are now in cultivation that the future agricultural development of the State depends. This w1ll be made possible by accurate and detalled knowledge concerning the character, varieties, adaptations, and capabilities of each of the twenty-eight soll types that have been estabI1shed. 


\section{Bivliography}

1. Second Annual lieport, Missouri state Board of Agriculture. 1866, p. 74. "Physical Geography of llissouri."

Fourteenth Annual Report, Missouri State Board of Agriculture. 1878, p. 152. "Nomenclature and Clasification of soils" by C. C. Swallow.

2. Iissouri Geological Survey, Vol. I, 1873-1874, p. 40. "Soils" by G. C. Broadhead.

3. Hissouri Ceological Survey, Vol. XII and others.

4. "The State of lissouri," 1904, p. 78, by Walter Williams.

5. Research Bulletin No. 3, University of Missouri, College of Agriculture. 1910. "Soils of the Ozark Region," by c. i'. Warbut.

6. "Soil Keconnoissance of the Ozark Rogion of liissouri and Arkansas." U. S. Dept. of Agriculture, bureau of Soils, 1914. By.C. F. lírbut.

7. Missouri Bureau of Geology and hines, Vol. IX, Part I. H. A. Buehler, Director. (Modified by E. B. Branson).

8. liissouri leological survey. vol. $\mathrm{X}$. "Physical features of lisissouri" by C. h. liarbut.

8a. "Geography of lissouri," by $\mathrm{H}$. V. Emerson, University of Iiissouri iulletin, Vol. I, INo. 4.

9. "A study of the soils of the united states." By G. N. Coffey. U. S. Department of Agriculture, Bureau of Soils.

10. Bulletin Ho. 12\%, "Soil Experiments on the Dark Prairies of Central and Irortheast lissouri." Missouri Agricultural Experiment station.

11. "Soils" by H. W. Hilgard. P. 285.

12. Dulletin iJo. 118, "Drainage Investigations on the Hortheast Lissouri Prairie." Missouri Agricultural Lxperiment station.

13. Bulletin io. 126, lissouri Agricultural Experinent station,

"Soll-Experiments on the Level Prairies of lortheast hissouri."

14. Bulletin INo. 128, lissouri Agricultural Experiment Station,

"Soil Experiments on the rolling Glacial land of ivorth Missouri." 
15. "Die Typen der Bodenbildung." K. Glinka.

16. Bulletin No. 130, Missouri Agricultural Experiment Station, "So11 Experiments on the Gray Pralrie of Southwest Missouri."

17. "The Evolution of the Northern Part of the Lowlands of Southeast Missour1." Vol. I, No. 3, The University of Missour1 Studies, by Marbut. 


\section{Plates}

Plate I----Geological Map of Missouri. M1ssouri Bureau of Geology and Mines.

Plate II----Geological section. Marbut.

Plate III---- Physiographic Provinces of Missouri.

Plate IV----Sketch Map showing Land Poorly Adapted to Agr1culture. Marbut.

Plate V----Contour Map of Missour1. Marbut.

Plate VI-----So1I Erosion Map of Missour1.

Plate VII----Per Cent of Improved Land.

Plate VIII--Diagram Showing Variations in the So1ls due to Erosion of the Rocks.

Plate IX--.--Per Cent of Land in Farms.

Plate X-D.-.-S011 Map of Missouri. 
See supplemental file for contents of envelope.

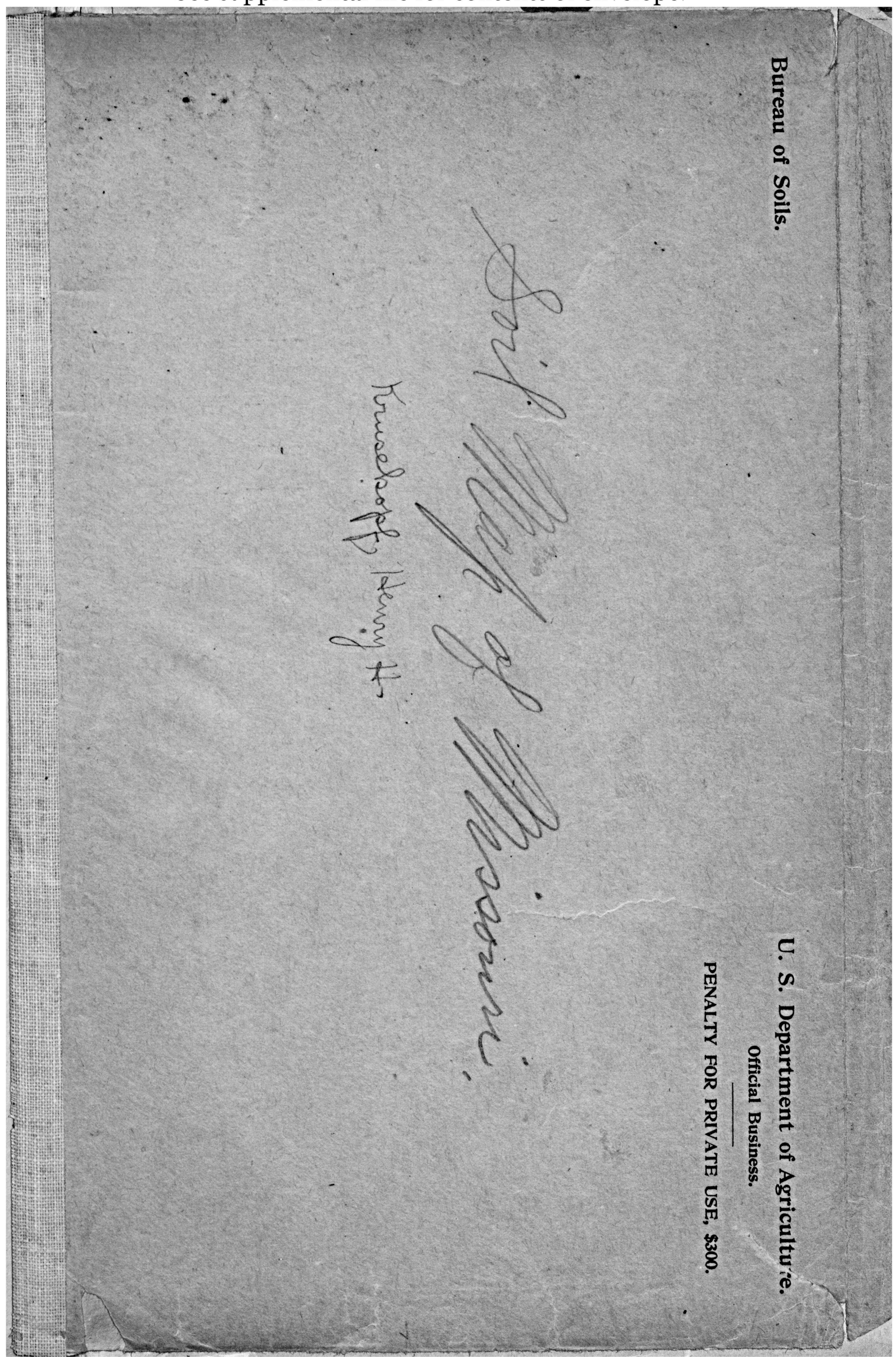




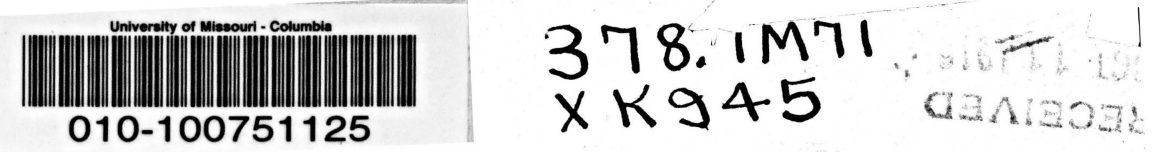

$378.7 \mathrm{M} 71$

XK945 
MU Li braries

Krusekopf 1916 Scanspecs, txt

University of Mi ssouri-.-Col umbia

MU Theses and Dissertations (Pre-1920)

Local identifier

Capture information

Date captured

Scanner manufacturer

Scanner model

Scanning system software

Optical resolution

Color settings

File types

Source information

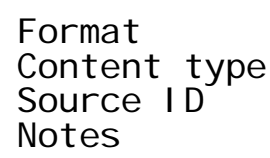

For mat

Content type

Source I D

Notes

st a mp.

Derivatives - Access copy

Compression

Editing soft ware

Resolution

Color

File types

Notes
Krusekopf 1916

20160531

Zeutschel

OS 15000

Omniscan v.12.4 SR4 (1947) 64-bit

$600 \mathrm{dpi}$

grayscale, 8 bit and color, 24 bit

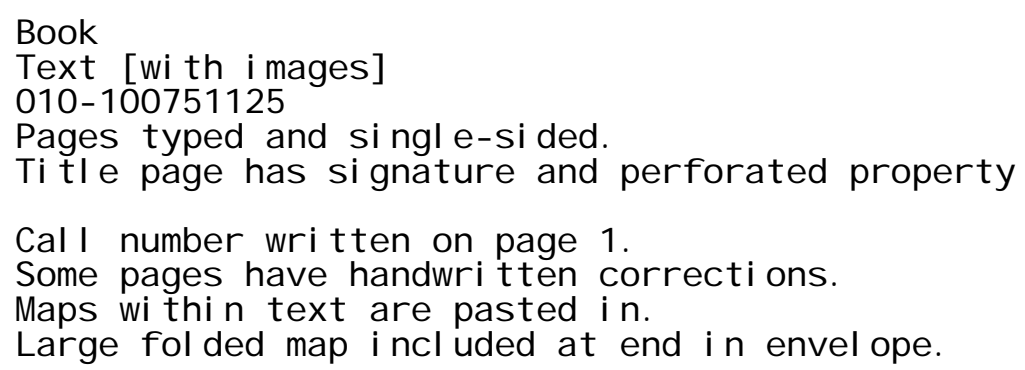

Tiff compressed with LZW before conversion to pdf Adobe Photoshop CS5 $600 \mathrm{dpi}$ Grayscale and color $p d f$

Grayscale pages cropped, canvassed, and i mages brightened.

Large map included at end was scanned in

six pieces and merged in photoshop wi th photomerge feature.

Color pages cropped.

Bl ank pages removed. 